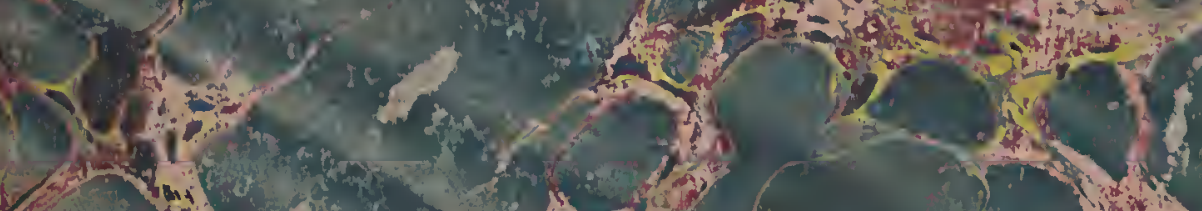

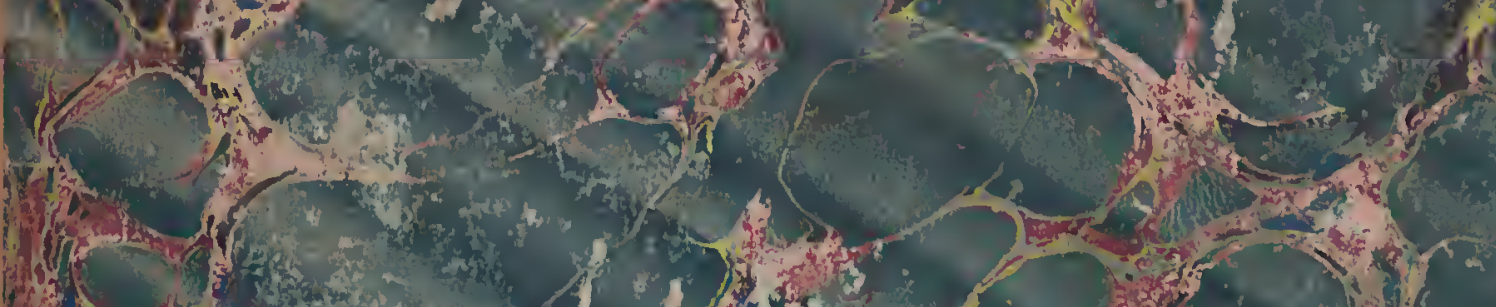

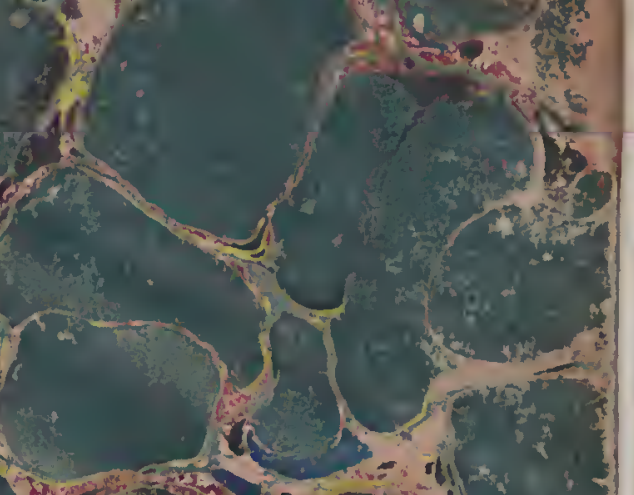

(1) $10+2 y$

$(x+2)(x+2)$

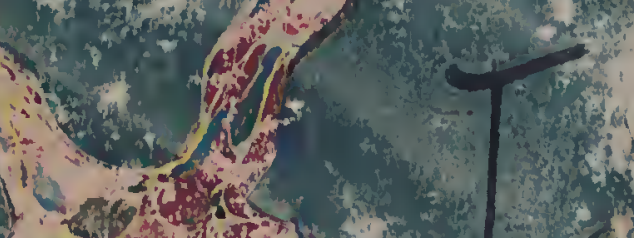

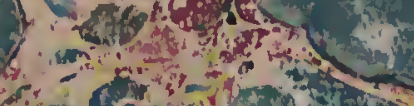

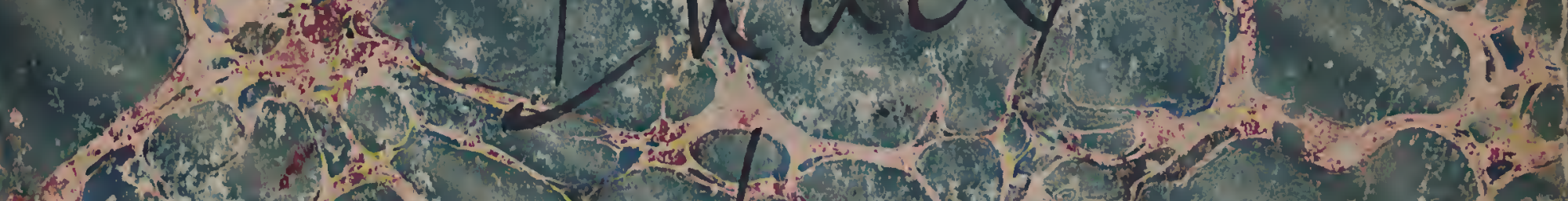

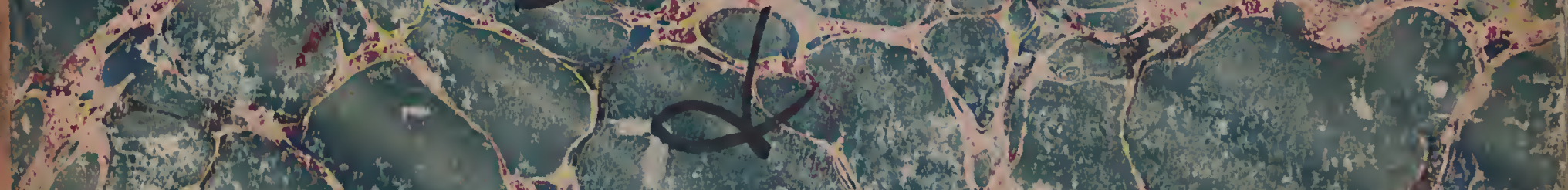
1.

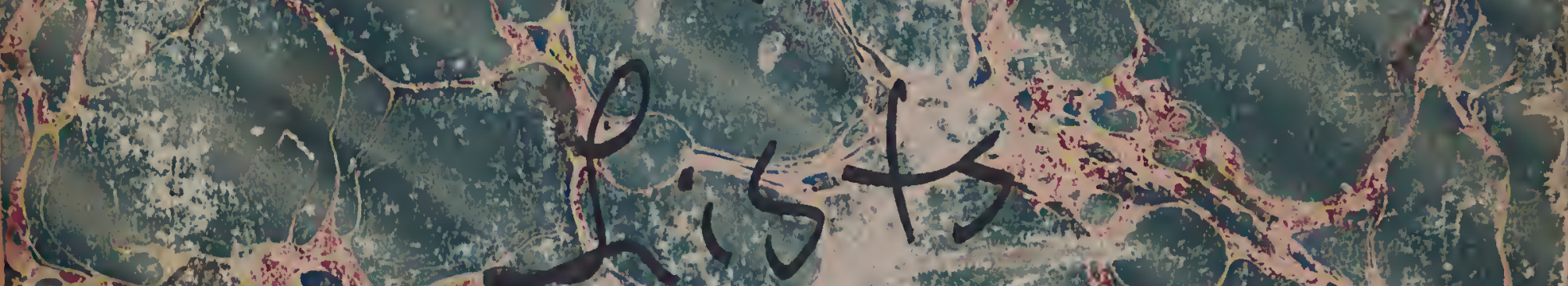

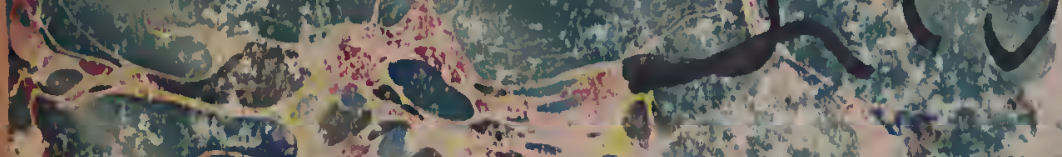

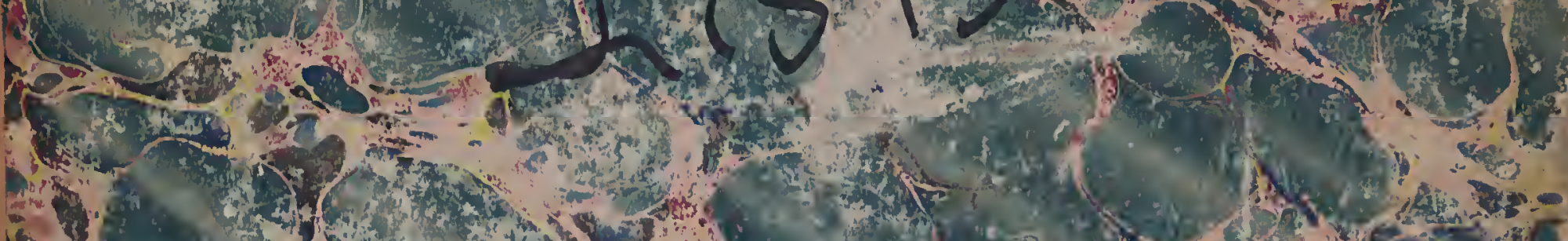

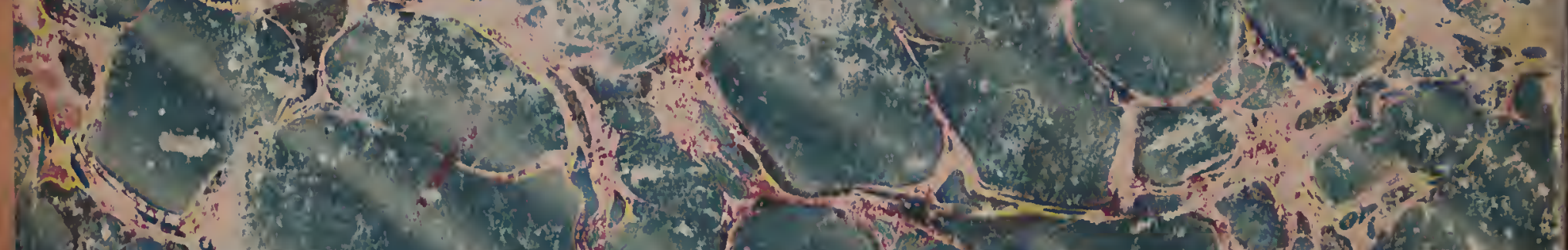

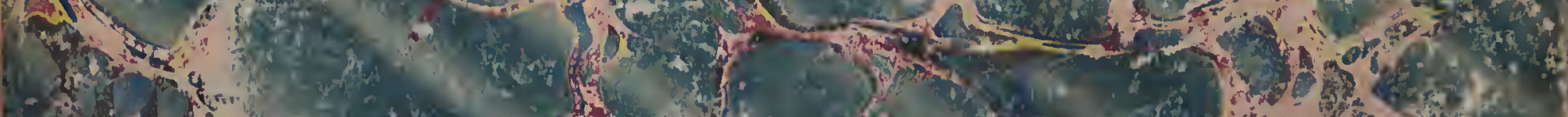

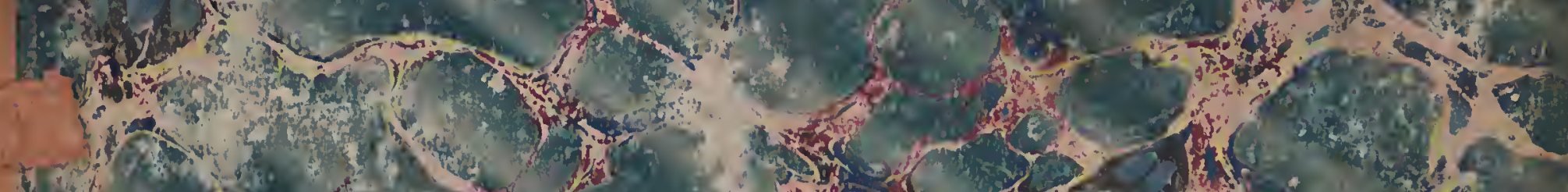

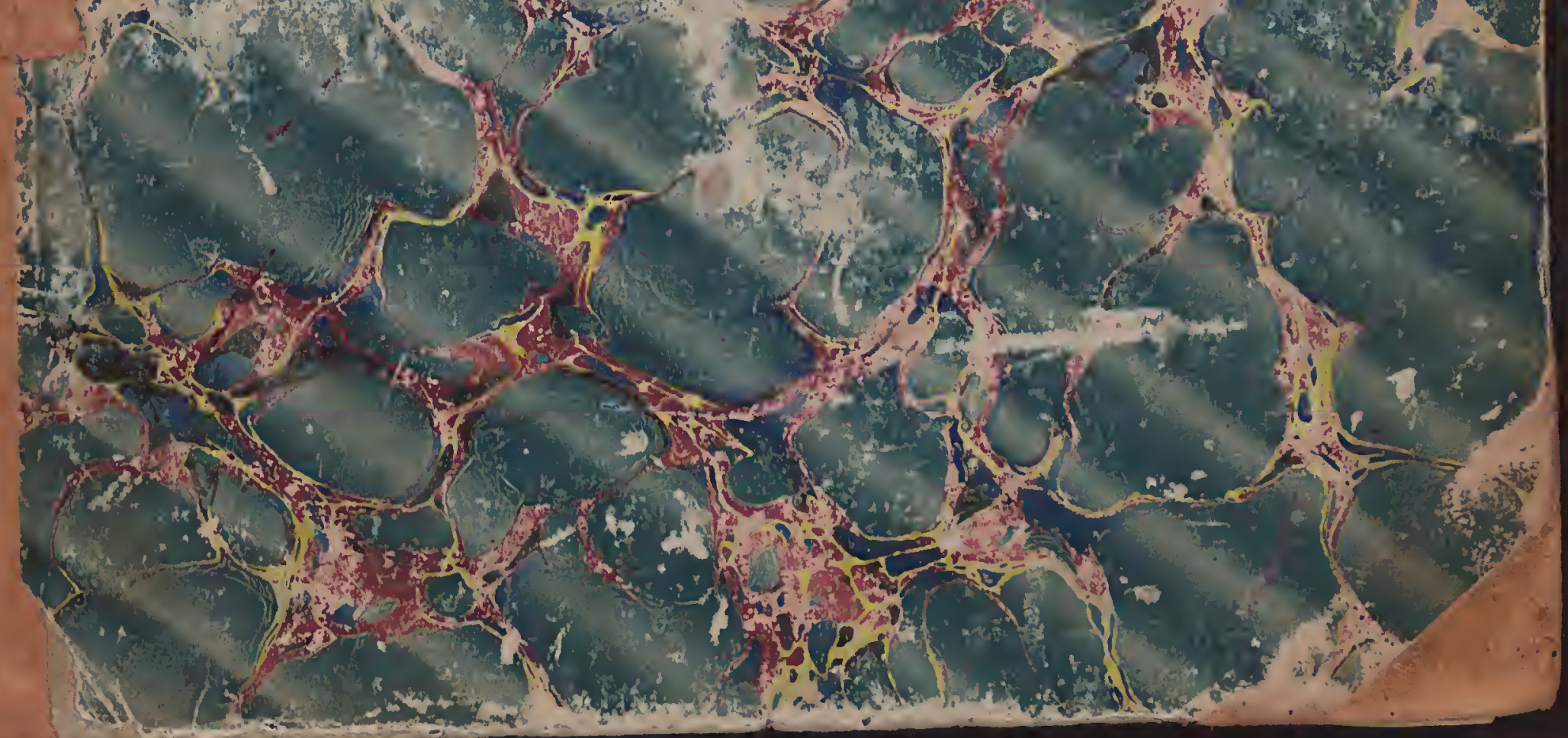


(2)

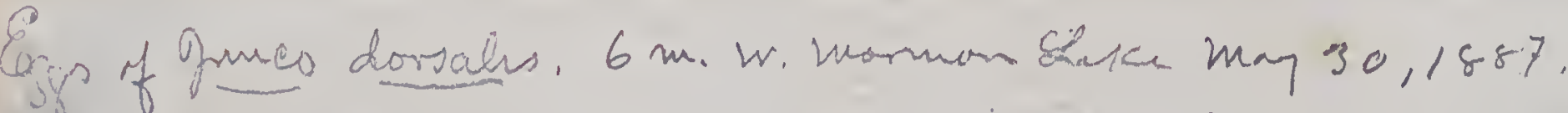
$15 \times 21,15 \times 20.5314 .7 \times 21.5 ; 15.4 \times 21$. Mest conceated

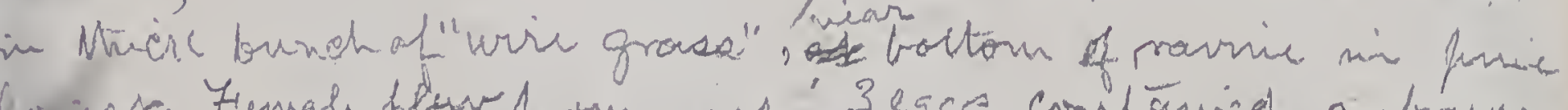

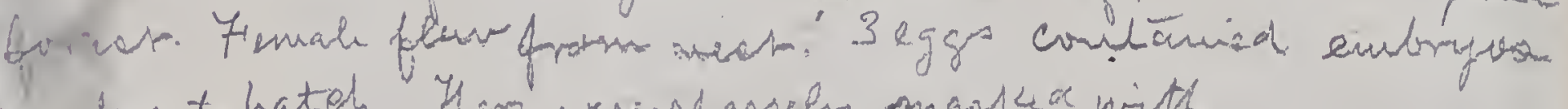
readry to hateh. Then were sfarsely maskex with color

- A forist log was addled arm bifigenes from the others in having the cirele of efots asound 1 to somale and. Ht nestr Mreserved.

Esp y Fulria anereana. S sets $(6,6,6,7,10)$ agcrecating

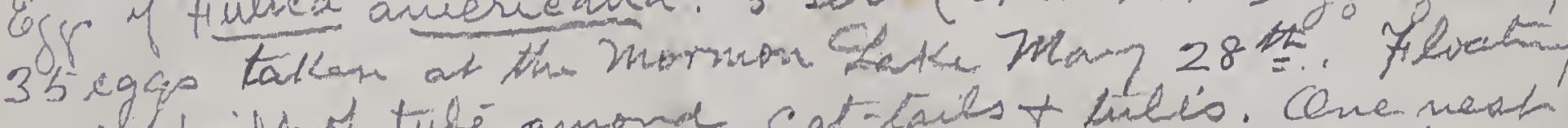
nesco brits of tule amond cat-tails t lintis. Cene nest

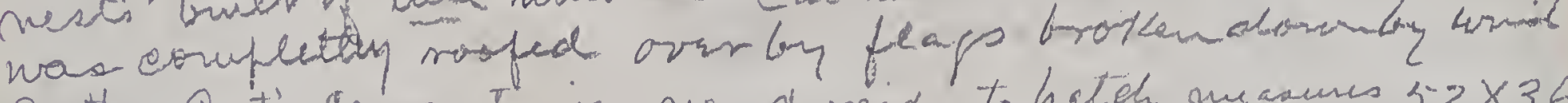

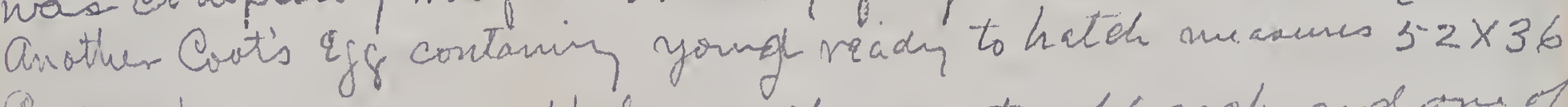
Seolecephains cyanocephahe. Zno sets of 6 each and ane of

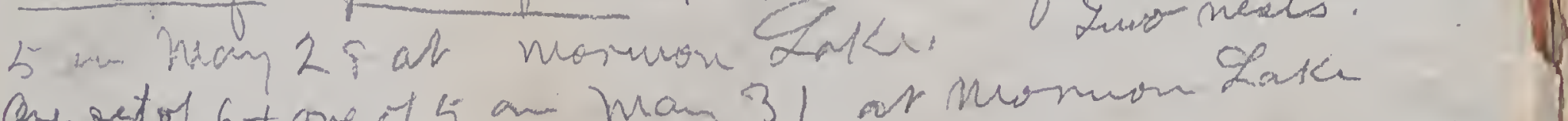

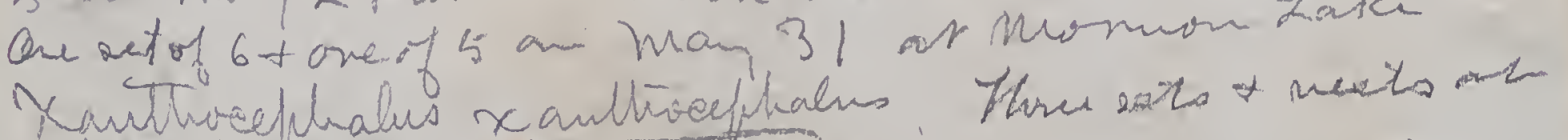

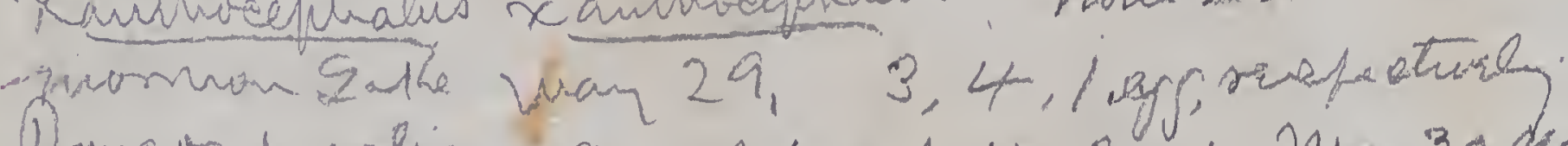

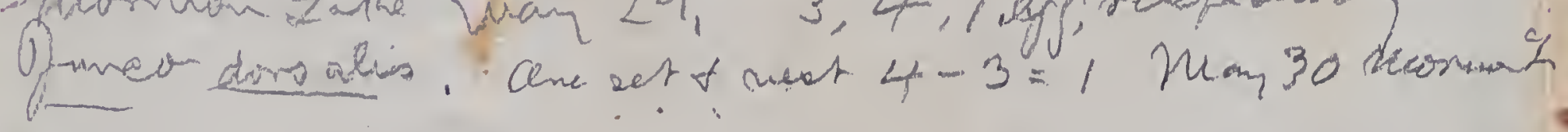

2 Nates of a Gelectmin Irip to thi elan Is sanaice Orsountiasis, Anzona Bray 20 to Gime20,1887.

Sist of the Andex at endiof books, which is a 2timerary of brif an fiage 9 . 
$(3)$

(4)

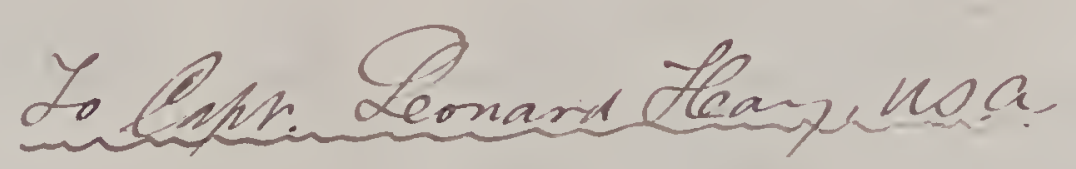

Cen Arzona's higheat freak

Dame Nature's treasures 9 did suk

Whilat restung on a log of apsuce

Dafuid this Cenchio lying lover

hrchere eropped and dropked on nountani Pheet

Cr wanderin Deer from eazons dep.

Aceepr the Glower as a boten

thas my esteen shall neer be brolun

Tho nameis Calyzar Gorralis.

Ir grew brside the eorydalis

in ald Newiziork wit was the farrest

in Arzona, the rareet. 


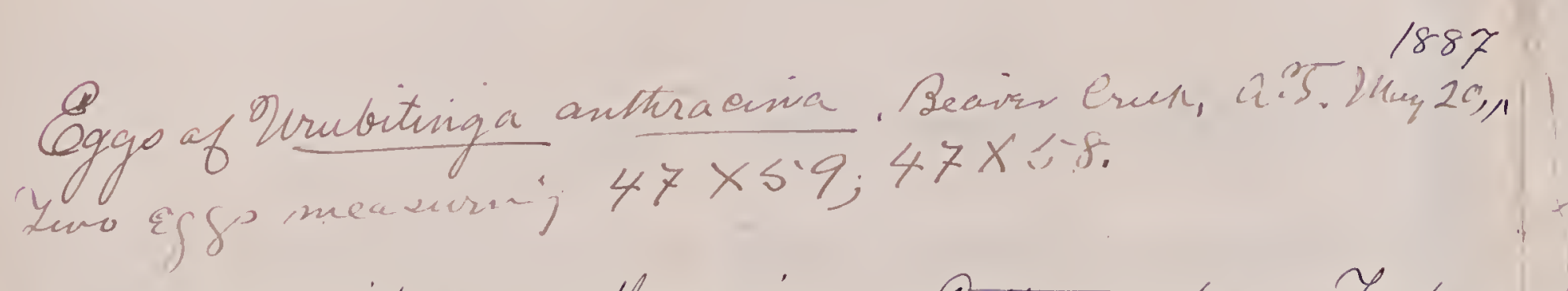
Eqga of Urubiting a anthracina. - Qollomoods on Zonto Crick, Ionto Basin, Bentrab Arizona. May 18,1888. Zwo $\operatorname{eggl}$, measurnig $50 \times 62 ; 58 \times 60 \mathrm{~mm}$.

Urinator inber. - a Soon was flying about

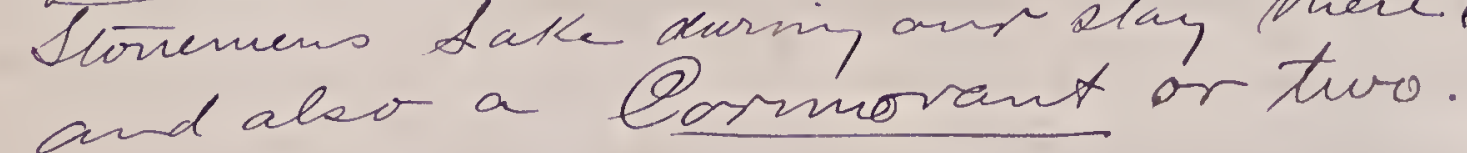

$\sigma$

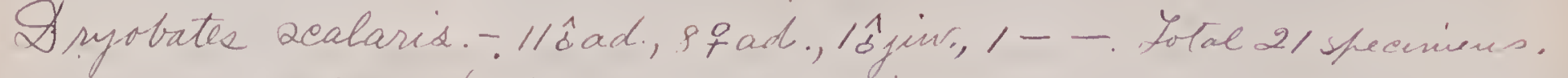

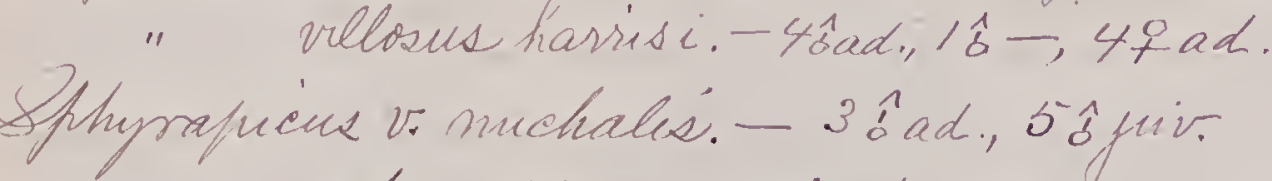

$$
\text { Aty roideus. - } 2 \hat{b} \text { ad., } 1 \text { fad. }
$$

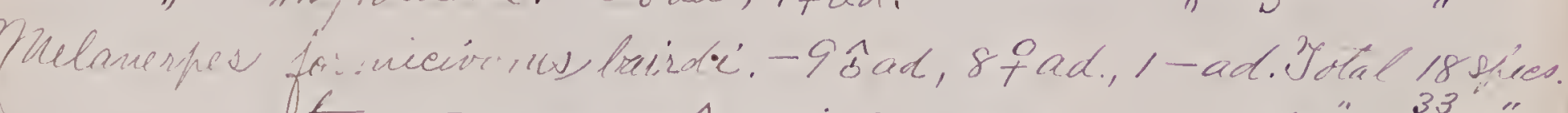

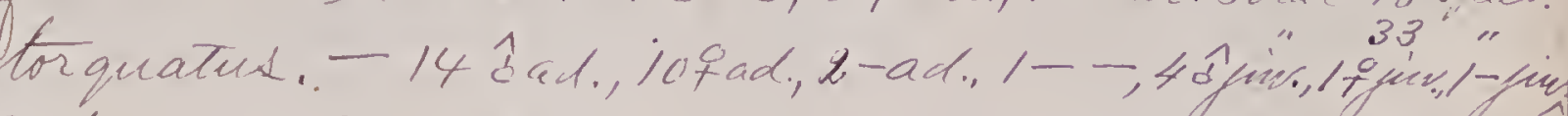

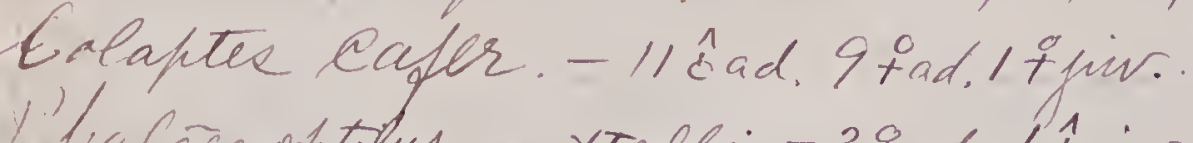

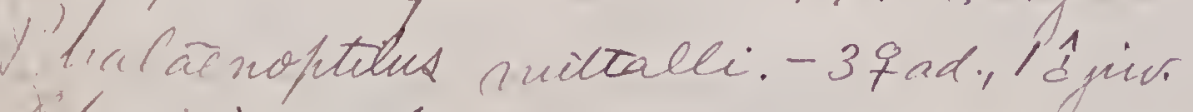

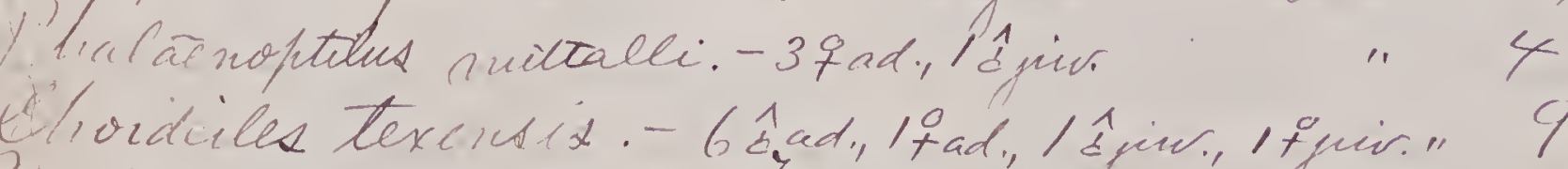

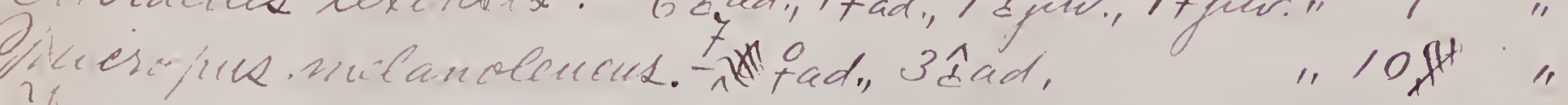

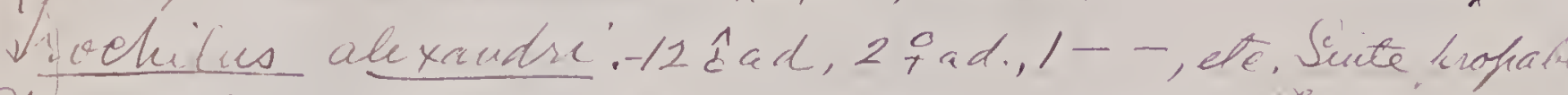

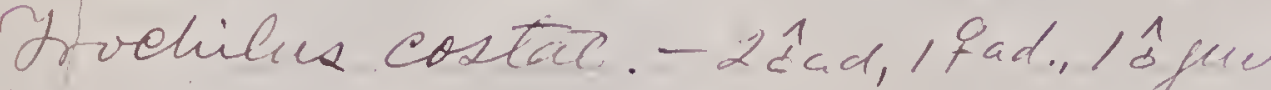

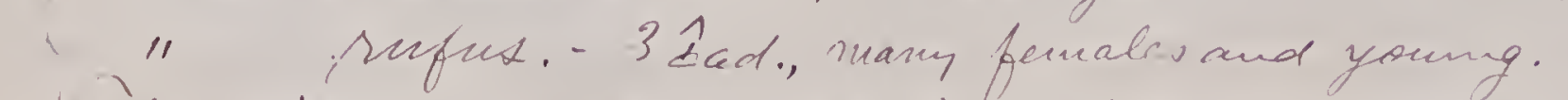

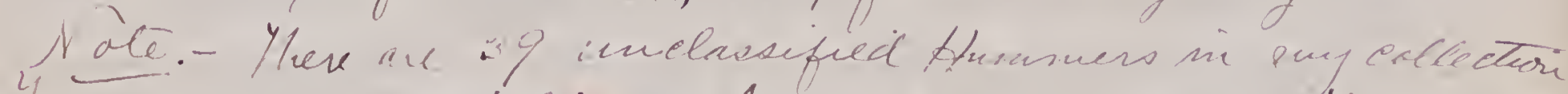

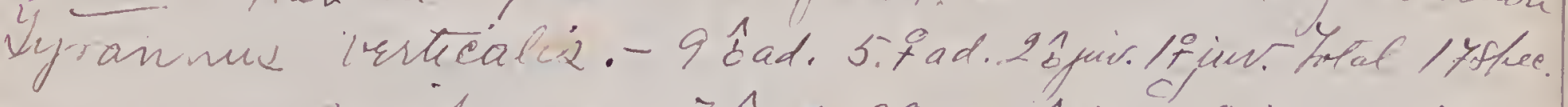

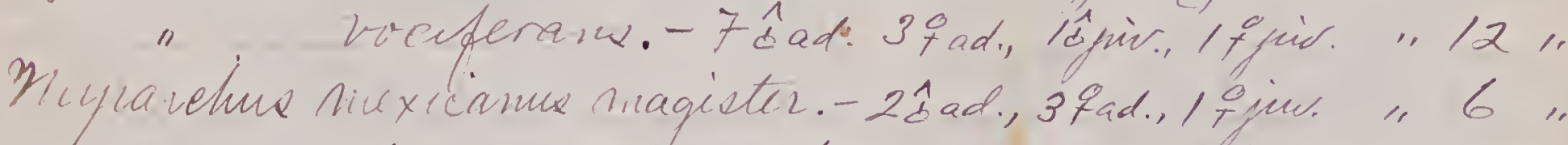
cimeraccens. -8ciad, 3fad., 2-ad., 1tim." 14"

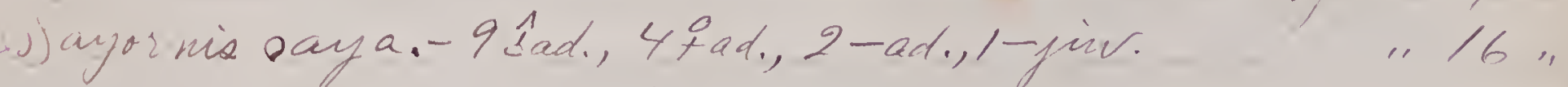

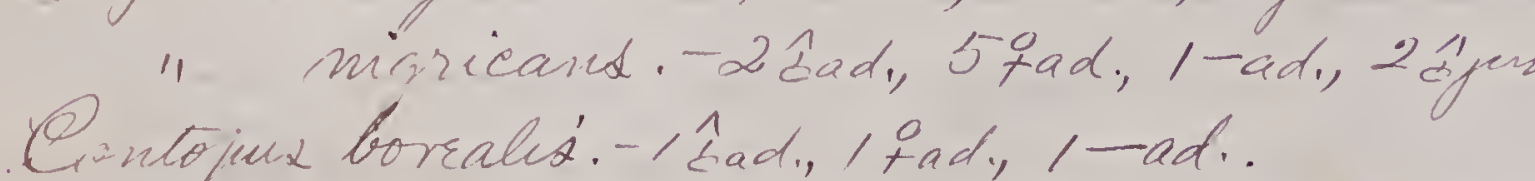

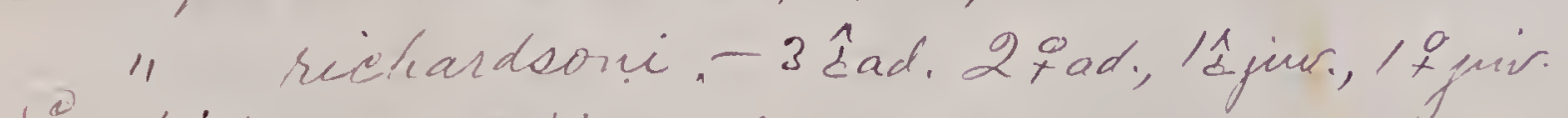

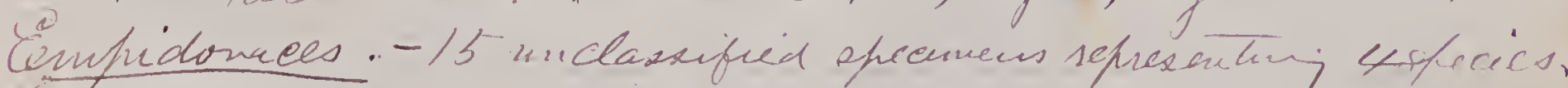
isufuidonax /nisillus. 2 fad.

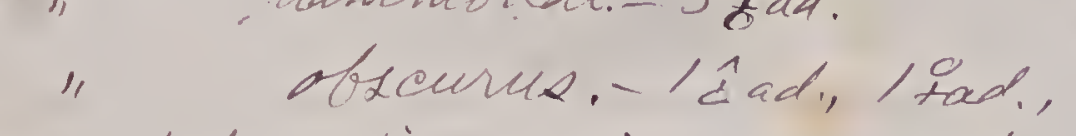

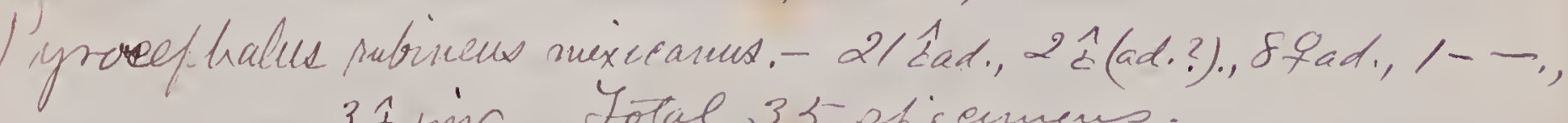

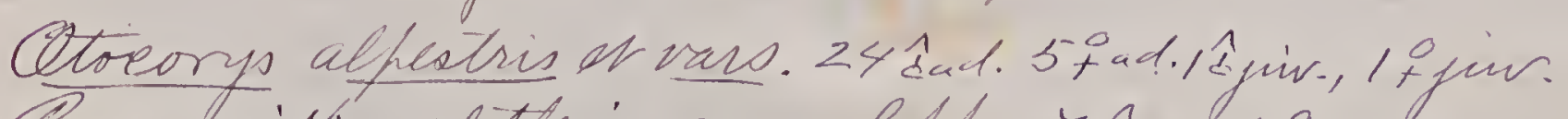

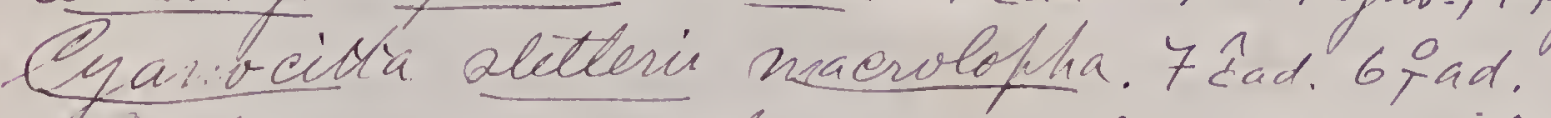

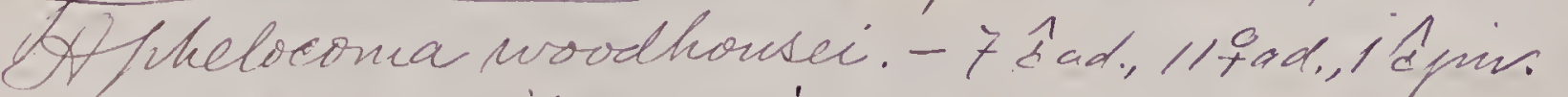

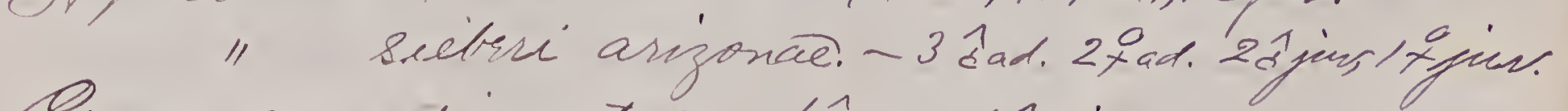

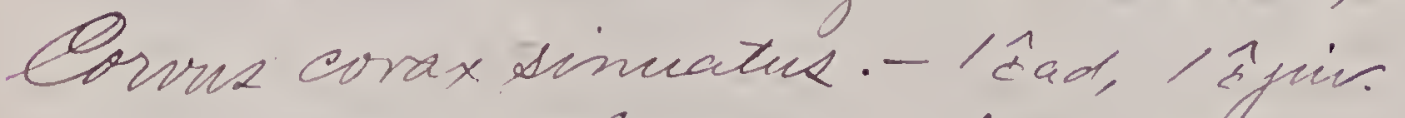

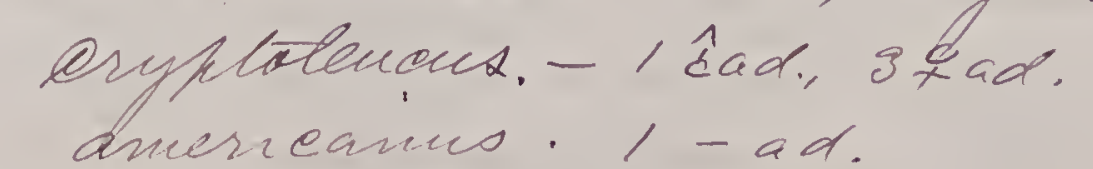

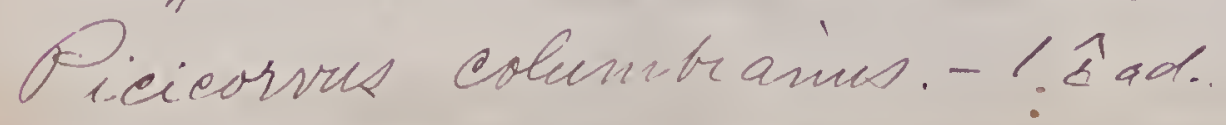




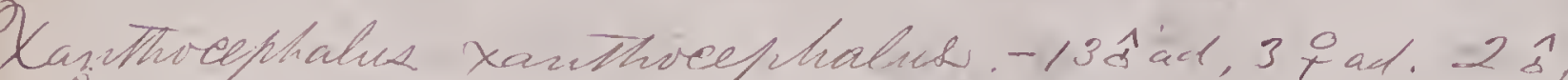

farinella

otime frari

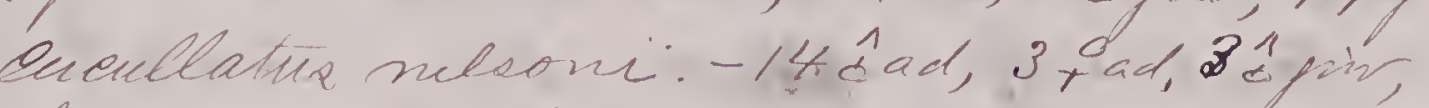

bulloeki. - $14 \hat{c}$ ad, s.iad, $2 \hat{b}$ gir.

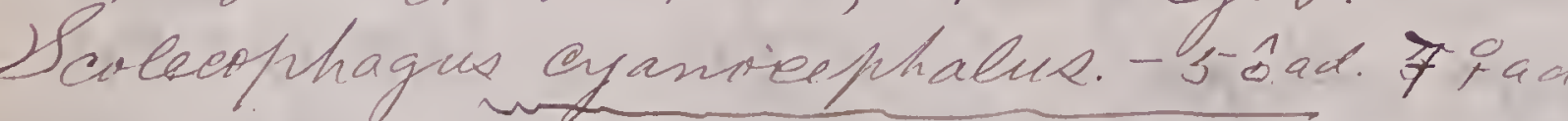

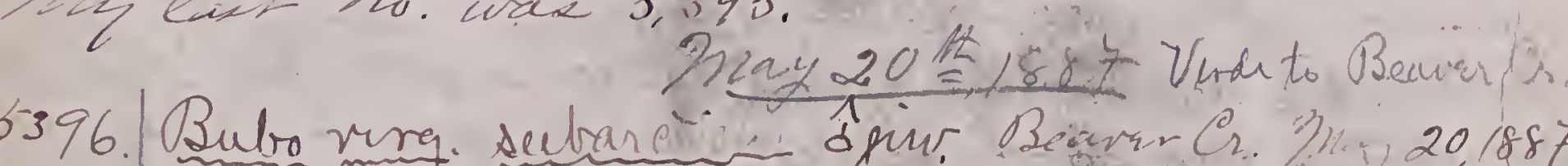

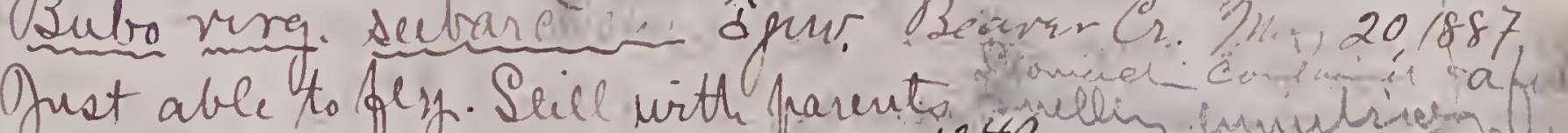
A 5397 Drubiting anthraema. ô ad.526:387:2.3.2 cultcere 36

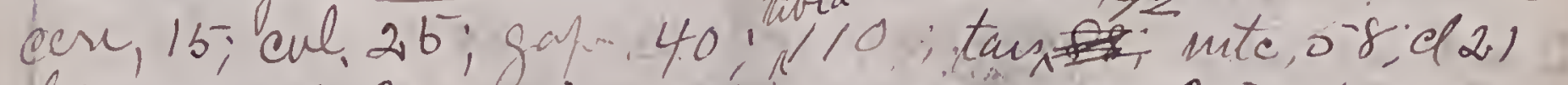
hte, 46;d, 25; smin d 2; outar d 17. Arides hazel.

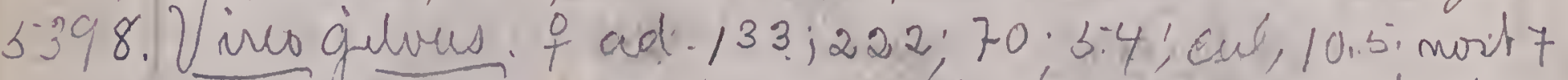

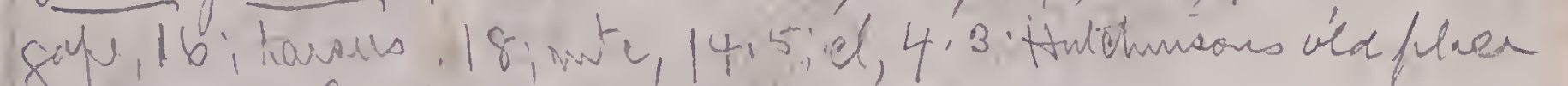
ambecuri Creek

\section{Man 211887}

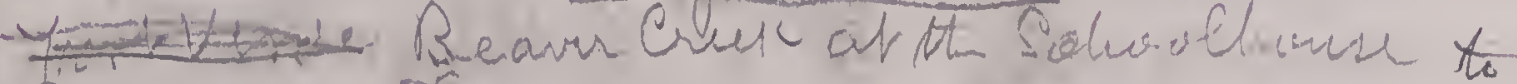
Stoneman's Lake, 16 miles

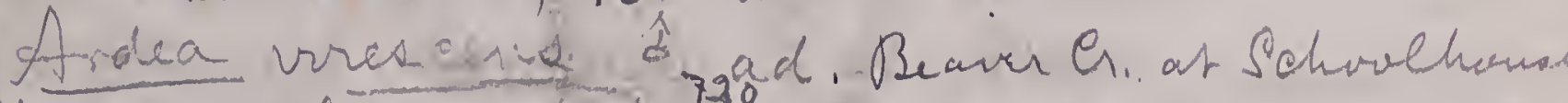

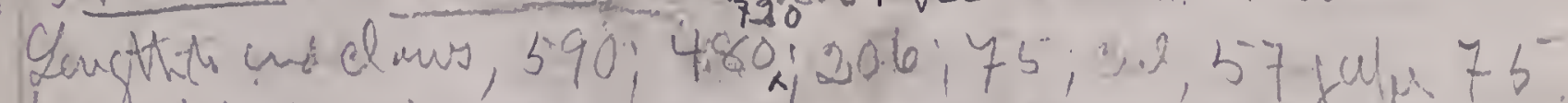

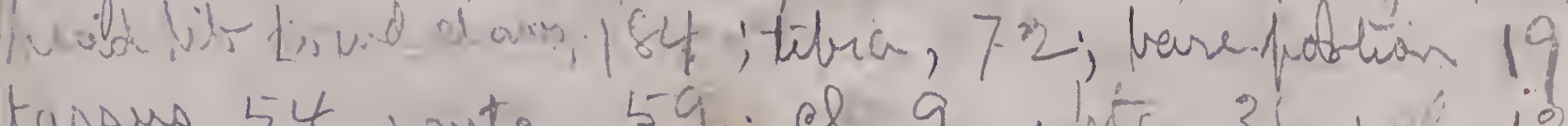
karsurs, 54 inte, 59 , d, 9 ; ite, $36 ; 0 ; 10.5$ Cardinalis eardinalis superbus, cad, 356:330,107,127.

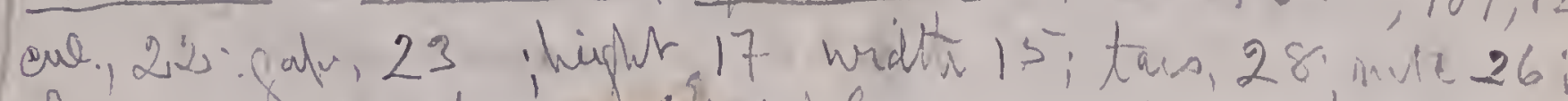

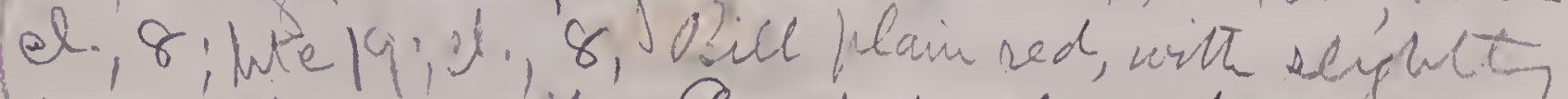
busky the to maxilia Iys, fut ticlaws frown,

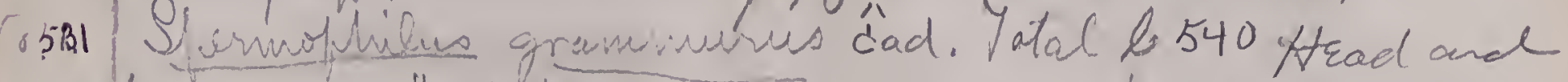

body, 290 Jaul th maverit, 190, to sud hamis 1265

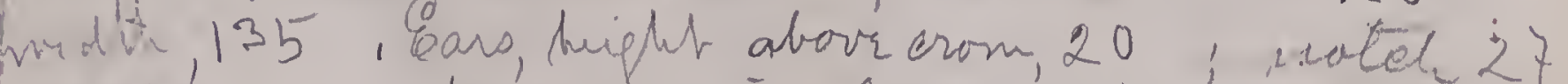
widith, 25 ; bat eyce, 35 ; loryest whikes 53

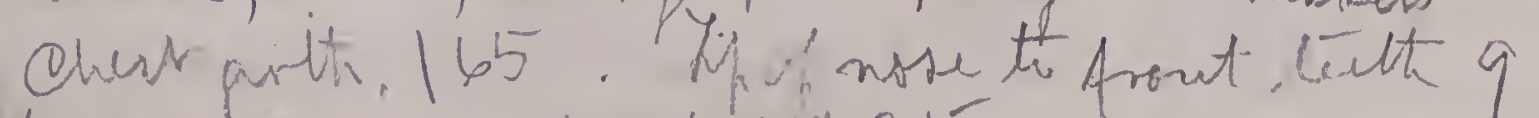
hasection
5401 Wrubitinga anthracmia tad. Beaver Guekt Wimo.

Panfrell:s samoth. Arides haze. 660; ; $405 ; 248$

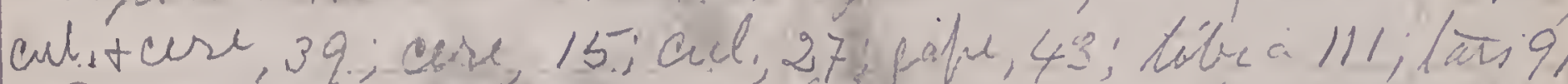

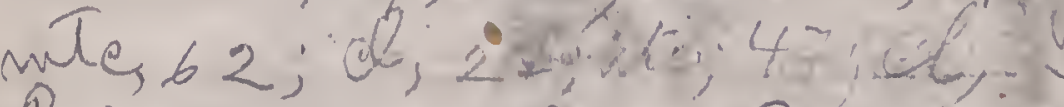

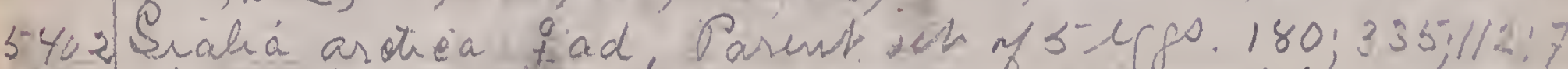
cul, 14; nst, 9.4, gav, 21; thentais, 23.5; ahte, 21; d 5 hte 14; el, 6 .

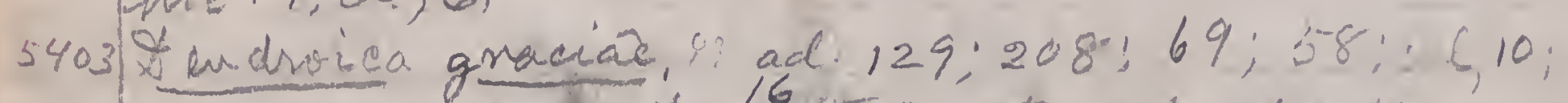

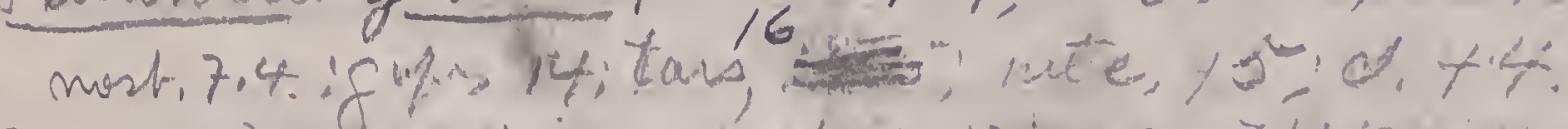

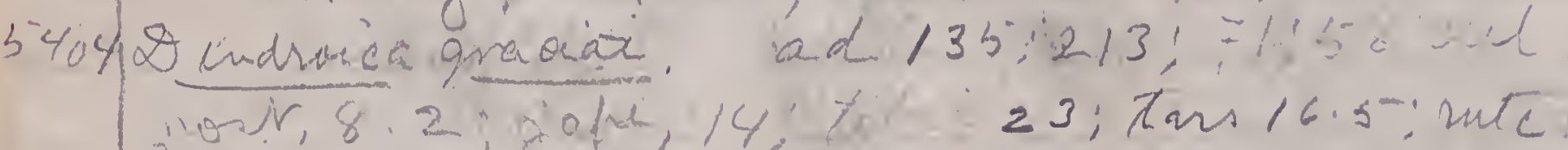

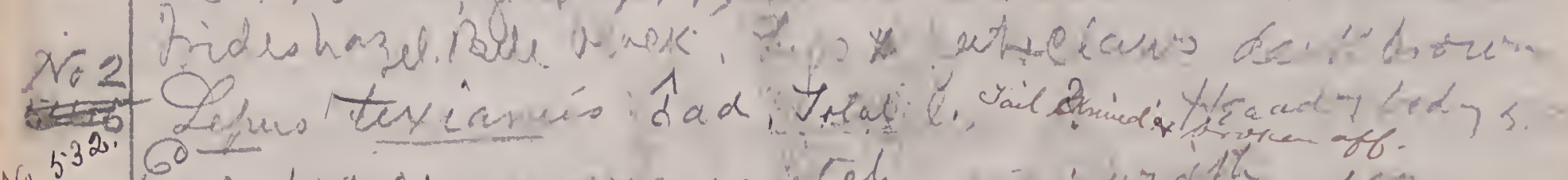

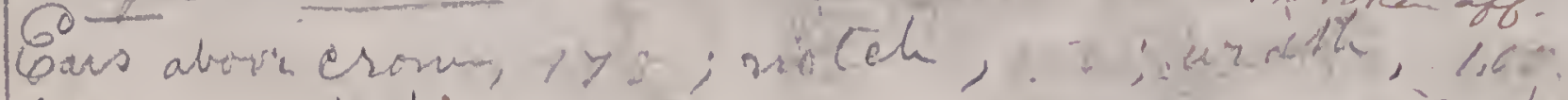

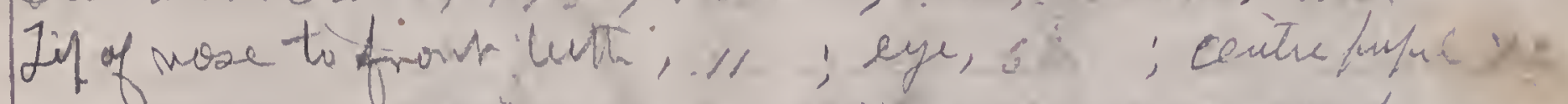

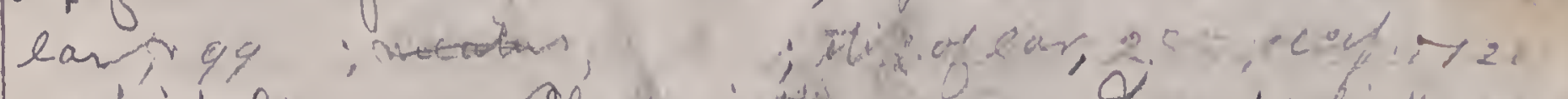

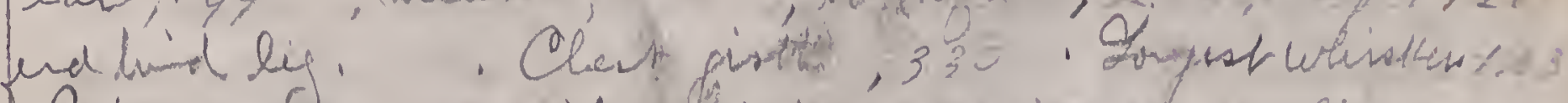

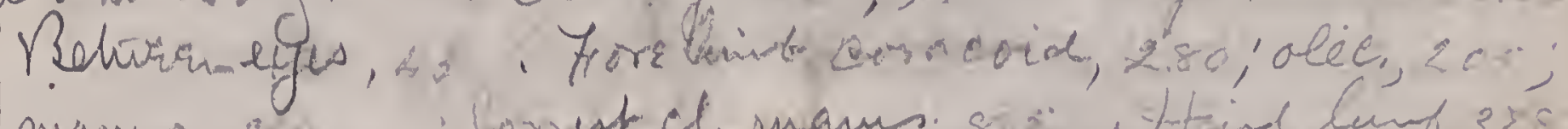

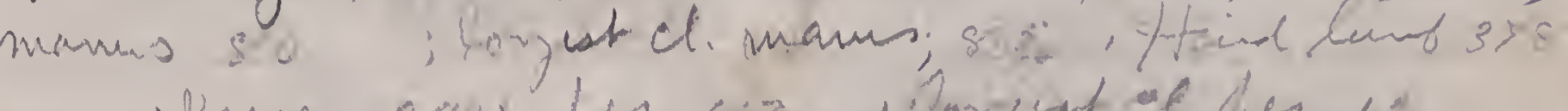

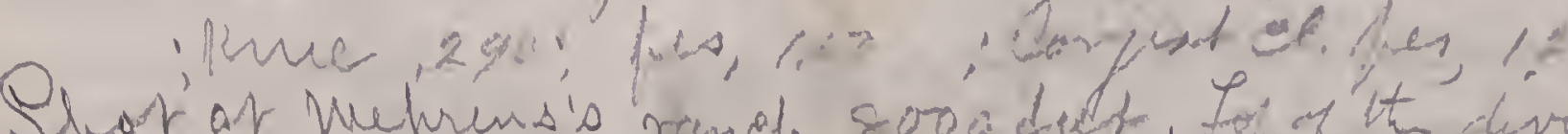

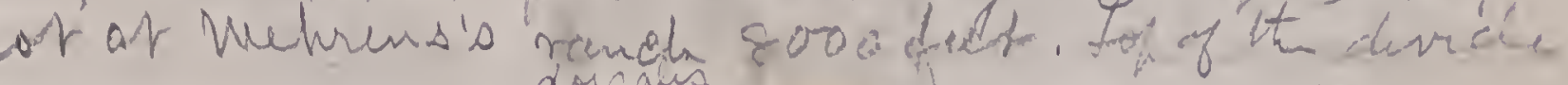

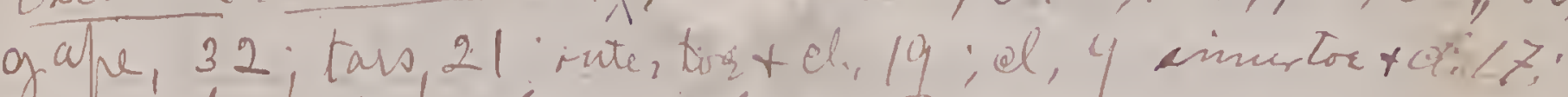

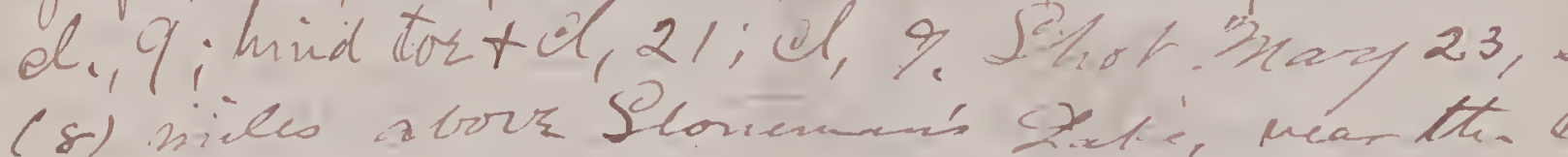

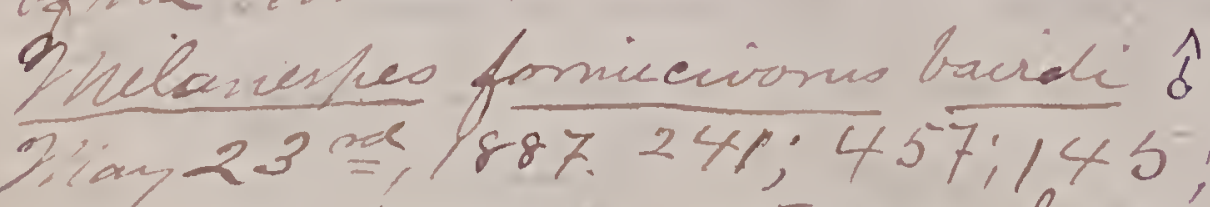
gatie 30 : tarsus 23 ; ante, $25 ; c_{1}, 9$. 
9

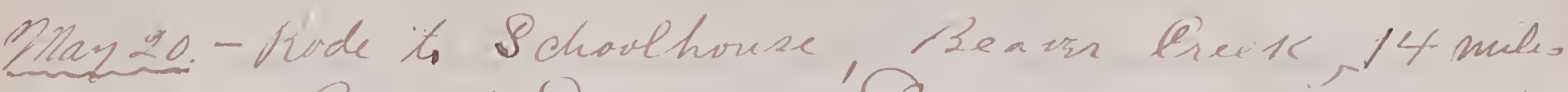

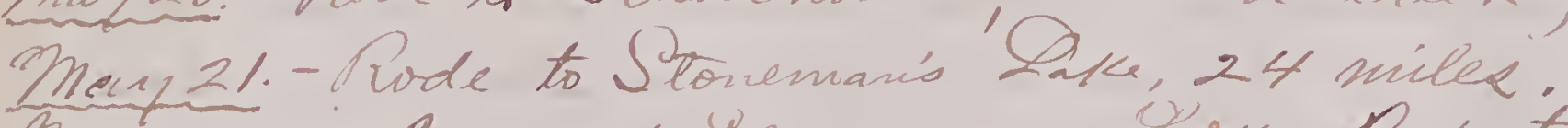

May 22, - In cam/2 Slonomanis, Rorle. Pode to the Sunvist ar Sohell' Ranch, 10 miles, to Sxamine body of numedered man for lowver a Sheirf

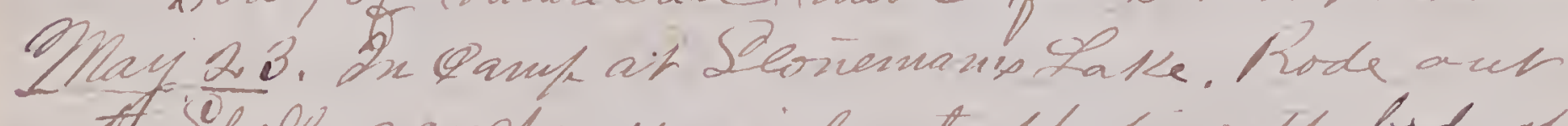
to Shells muche, 10 . nules, to photongrafth body of muedered, main.

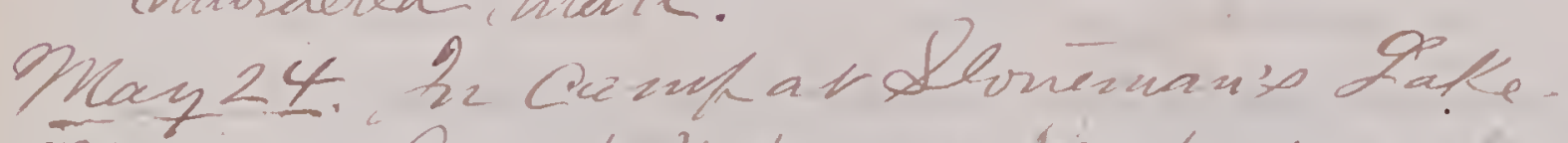

mnay 25 Rode to hetirensis karch 10 mices

man $26.2 n$ eamph at " "

Eman 27

"uimi28. Mode to "Monmon Lake"

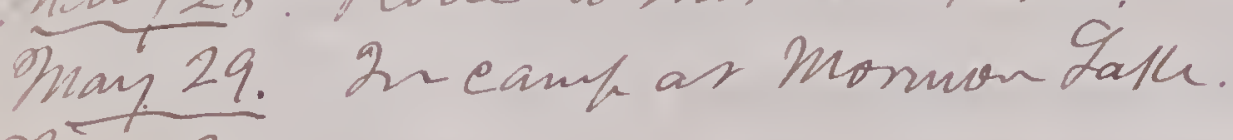

Milow 30 " " " " "

"Min 31 Rode 14 minles to Clavk's Panle

Dhue 1st Rode 12 " "Glaystaiff

Ame $2^{2 d}$ " 3 " "Spring Wrof thla yslaff

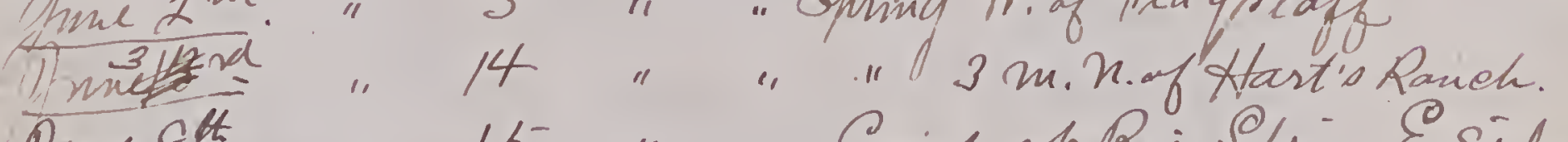

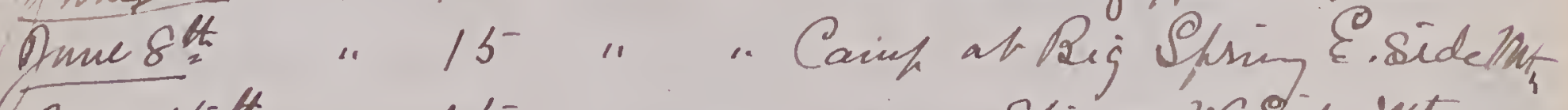

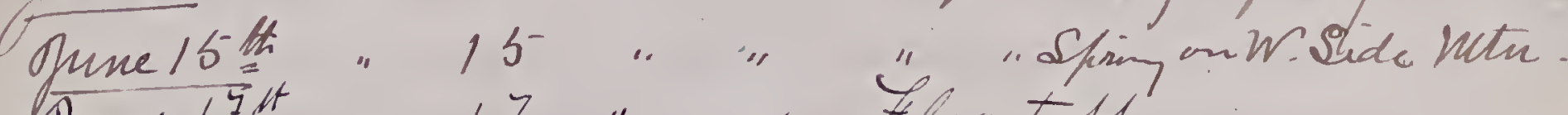

June 19" "17" "Flagetaft.

2 me 18 22 " Mums's sanch

ome/9然" 15 " "Palteonak Yout

Opme 20" 25 ". "Fort VAnde, Arizon

g code 294 miles braides when huntro 


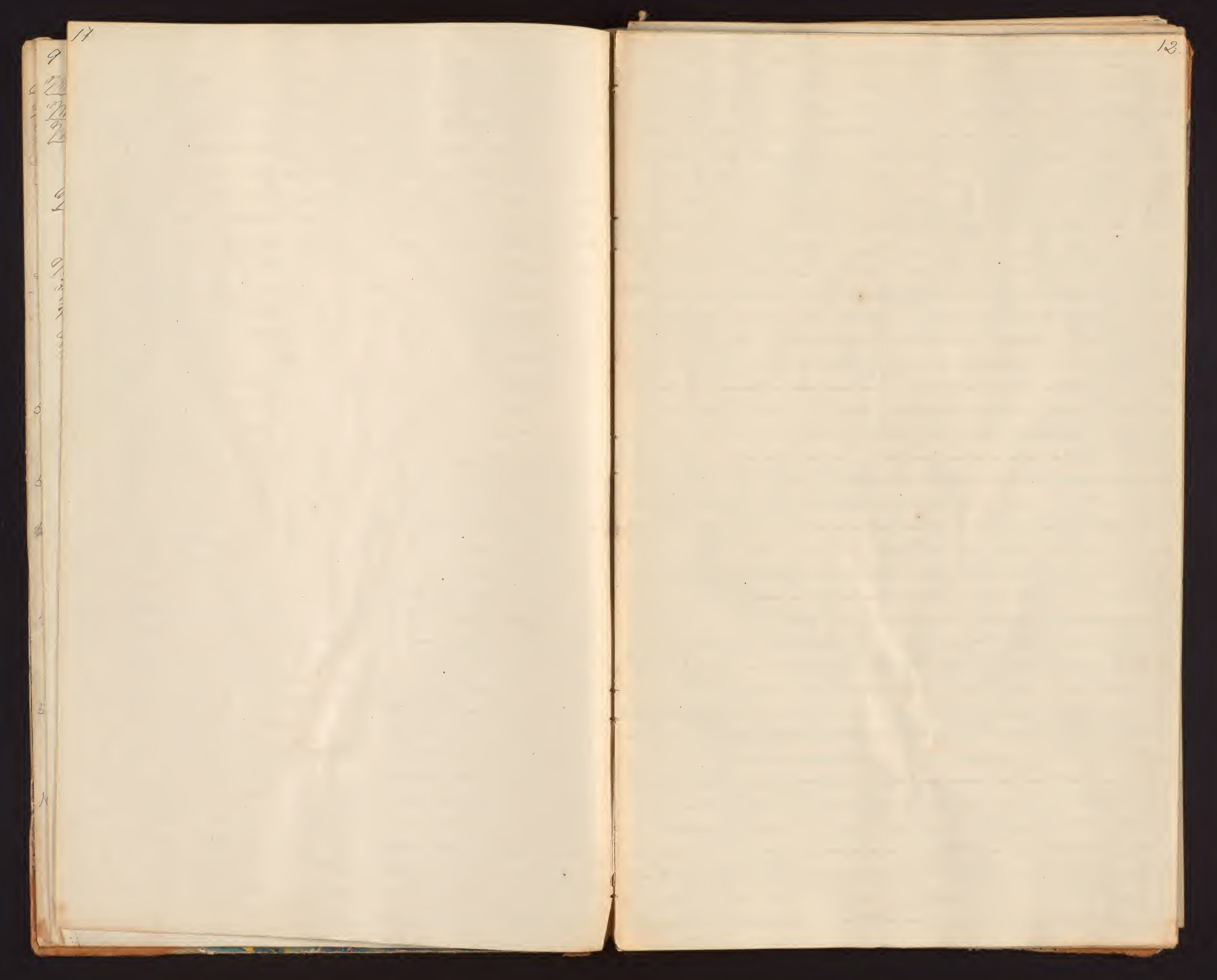




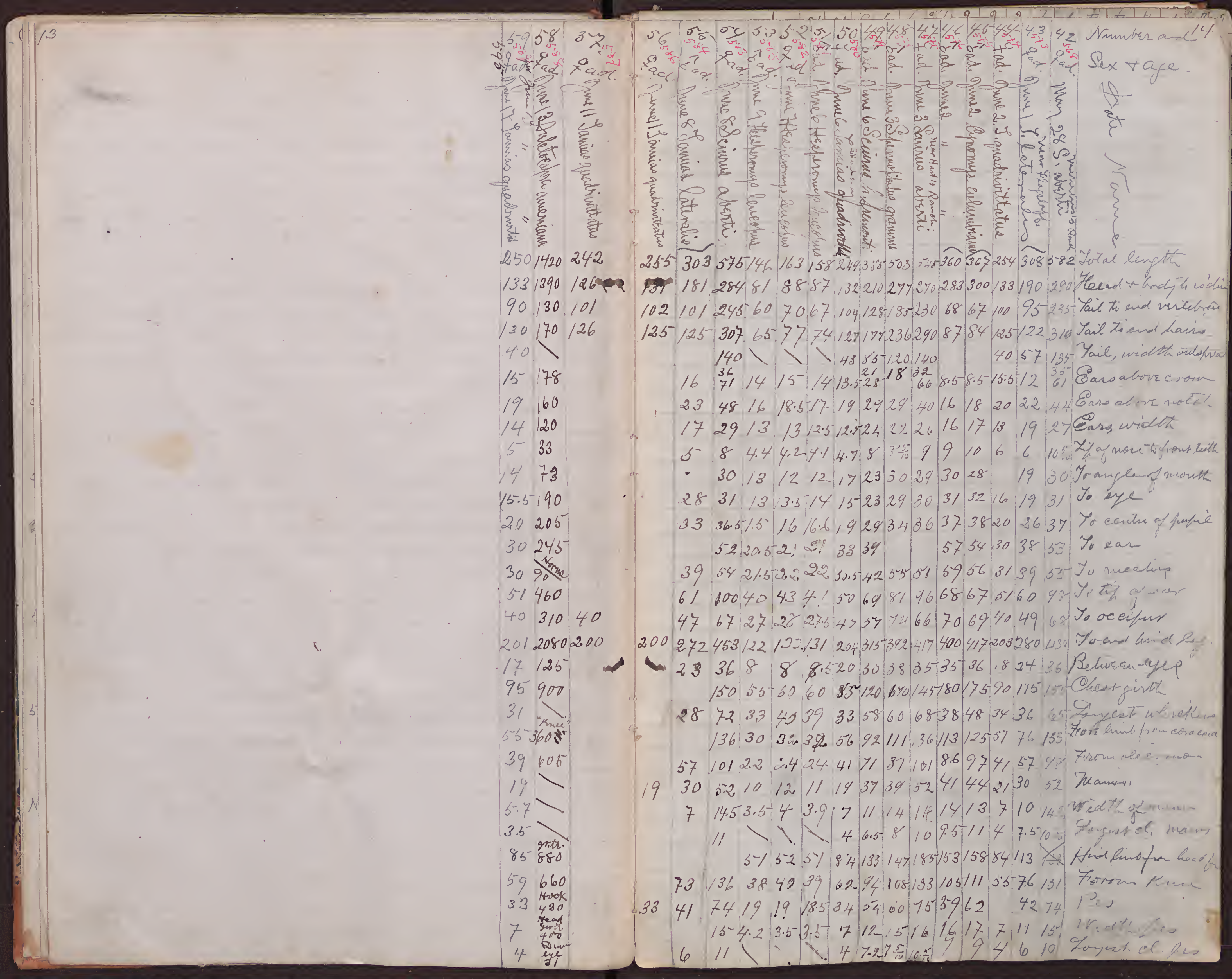









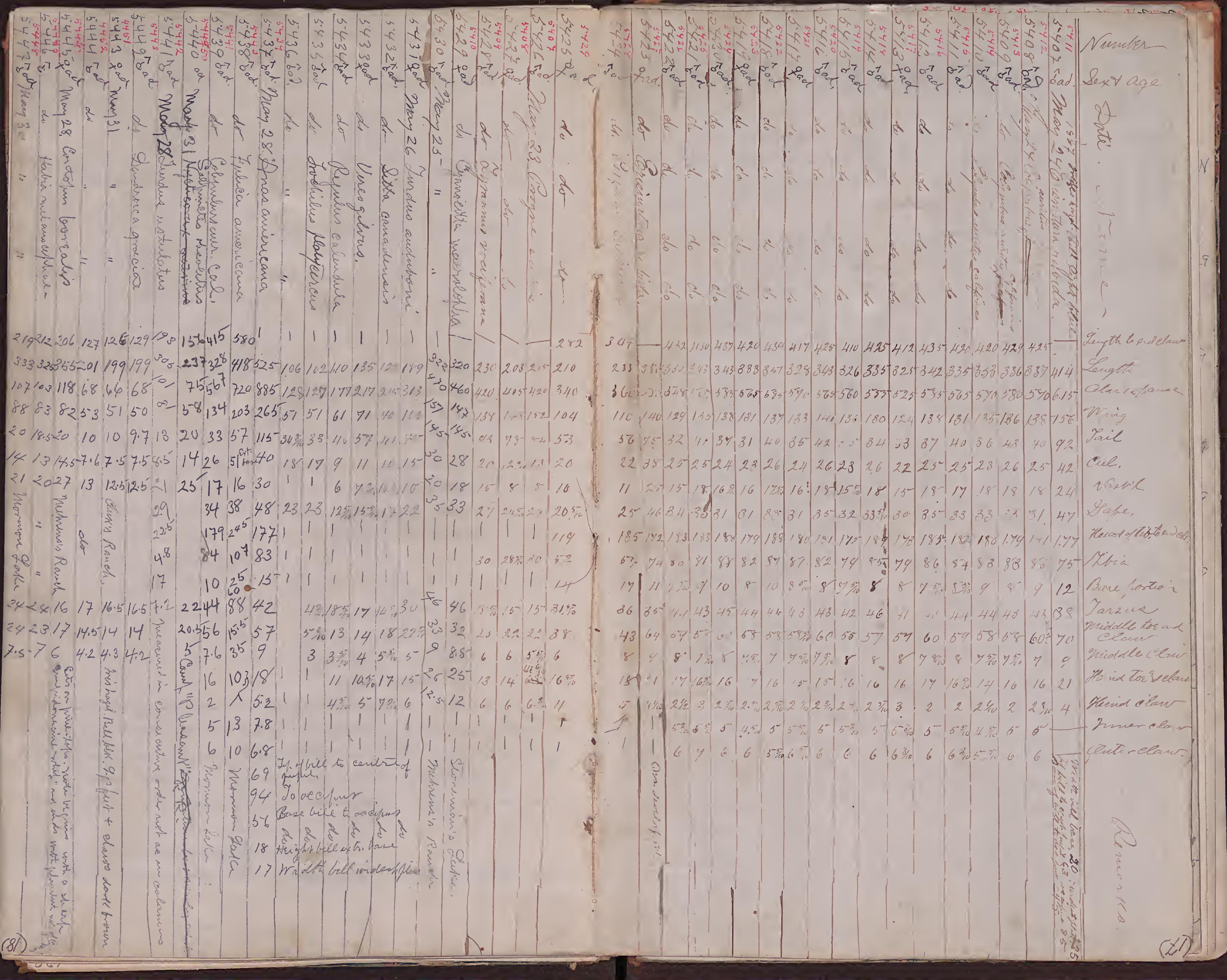


Drang P11867

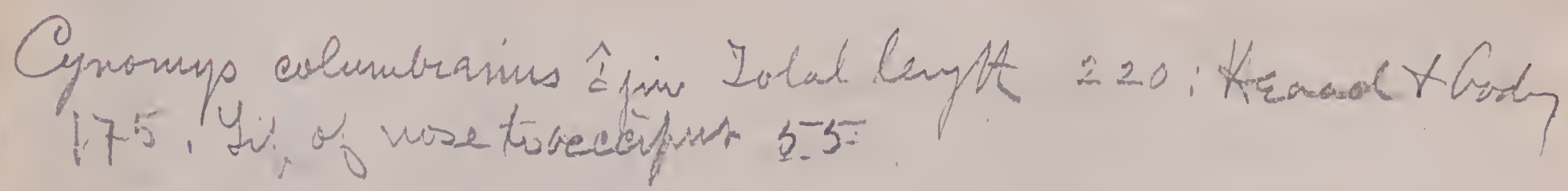

Lame. - A Eell was seen at Mormon Lake which nar frobably thr form of Lams delavarensics which I have called "alemi" in mis. It was on Hth Slase the day we arrind (May 28) but left brfore we abterufted to secure a ofeenien. 



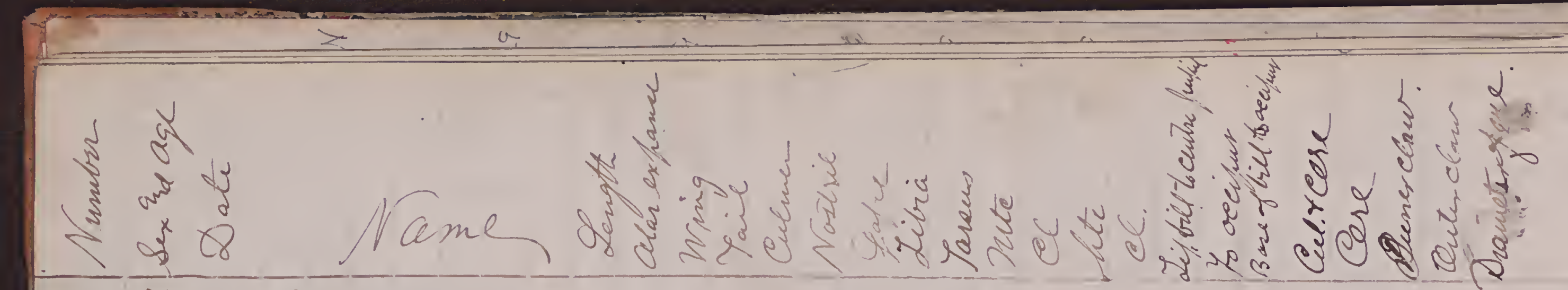

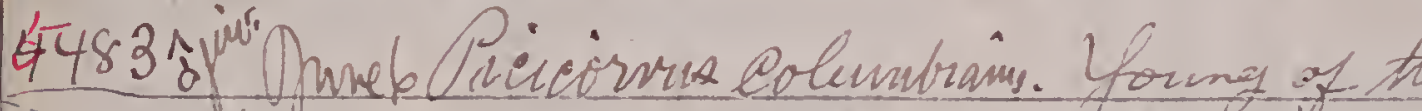

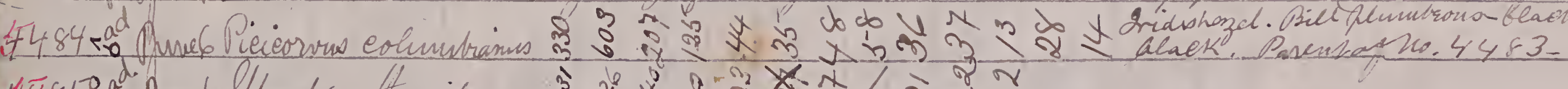

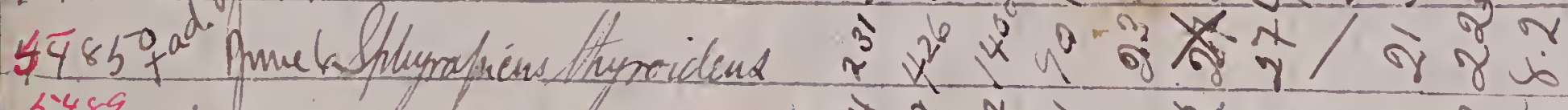
4486 id d Muct Prime. V. harrivi

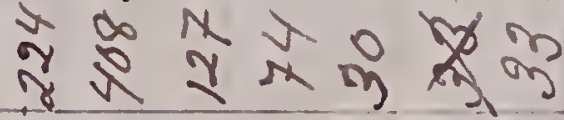
g.

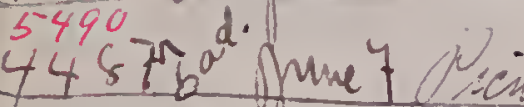

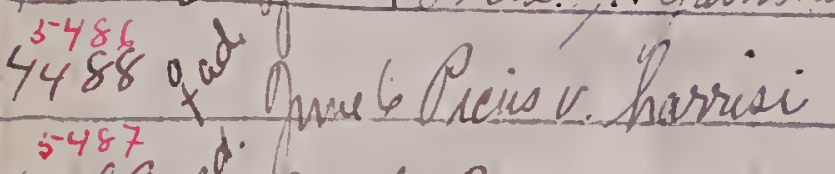

$4489 q^{20}$ Dume 6 Anev dorsalio

$4490 q^{a^{\alpha-}}$ Punel Dendriea anduboni

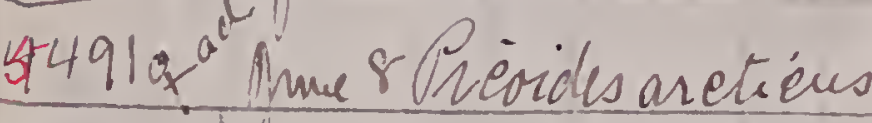

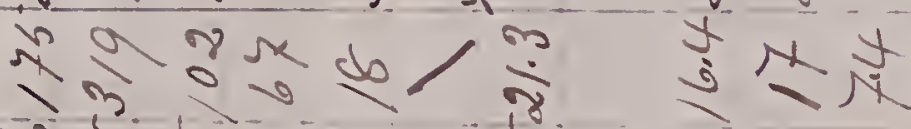

₹

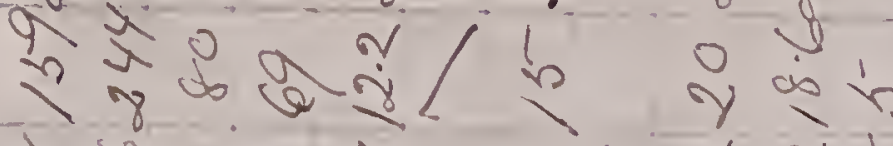

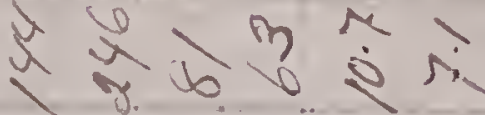

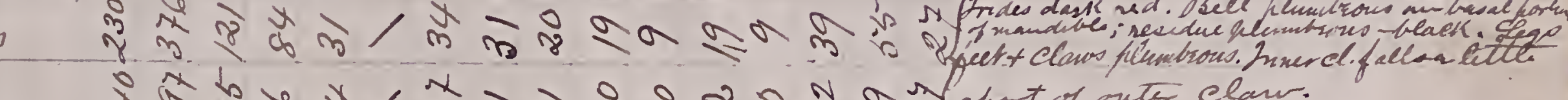

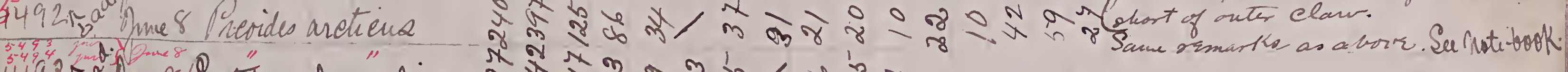

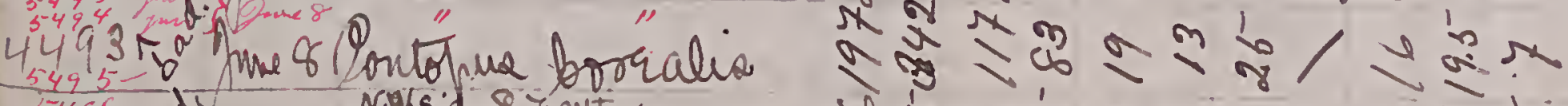

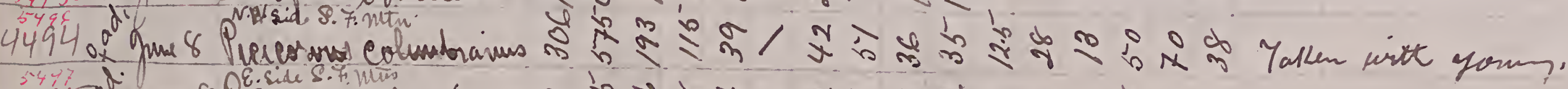

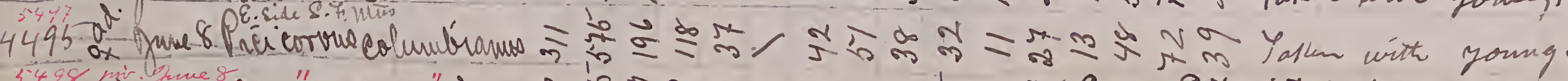

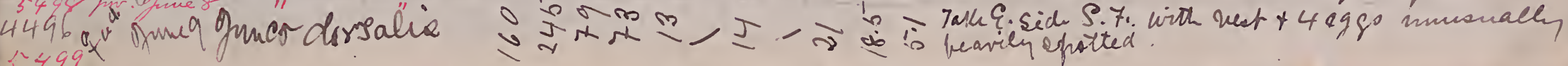

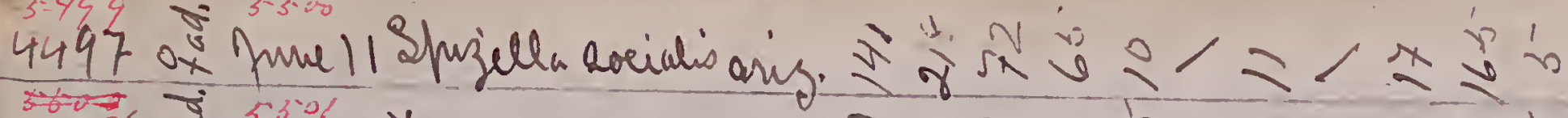

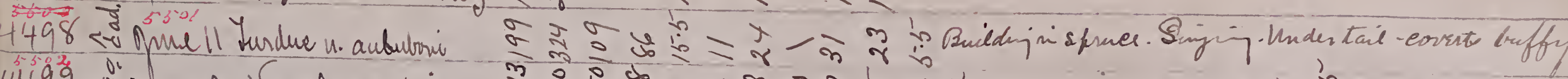

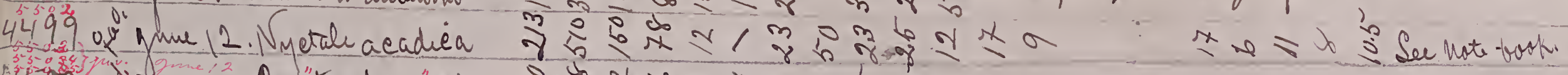
4.

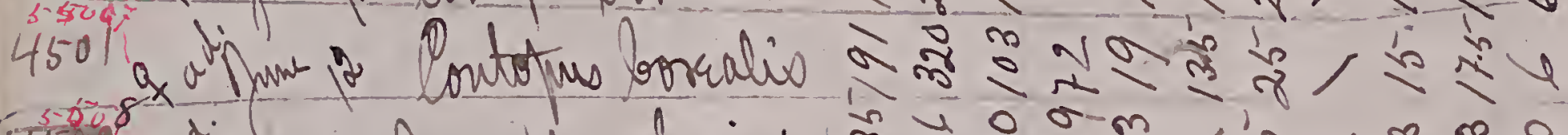
4502
20

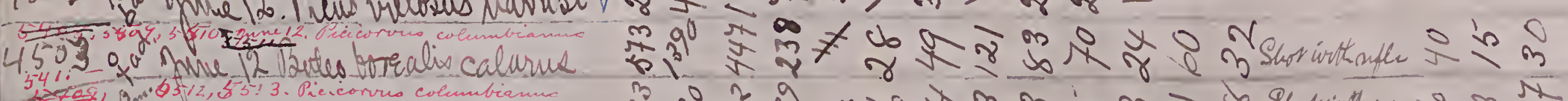

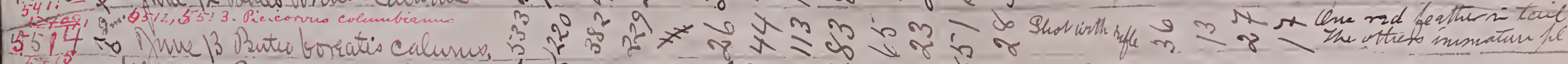

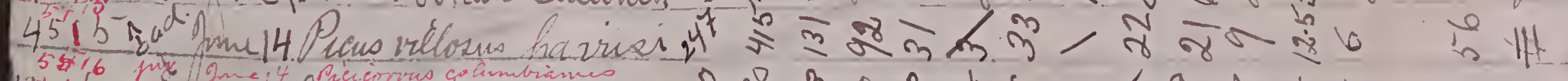

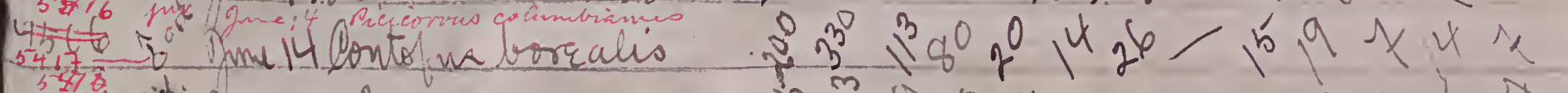

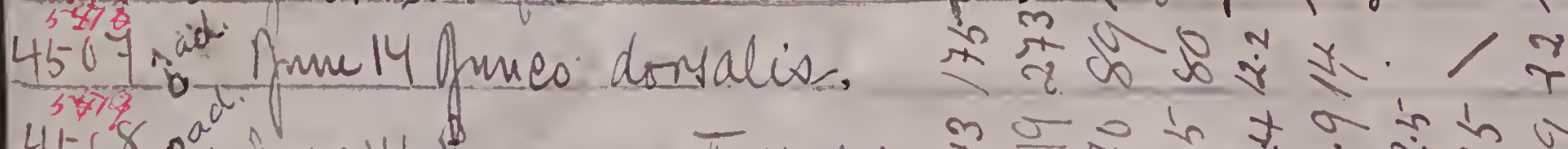

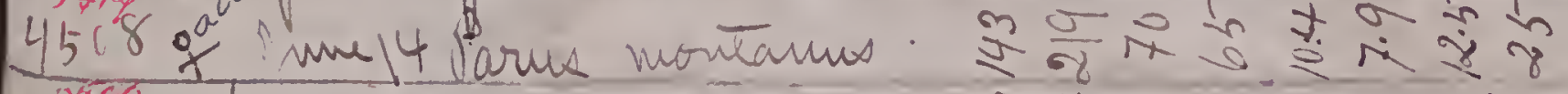

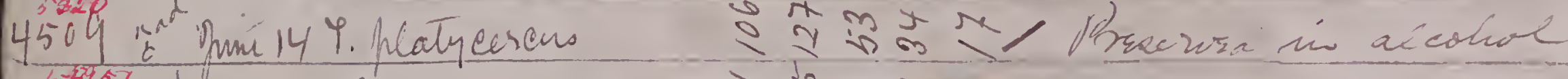

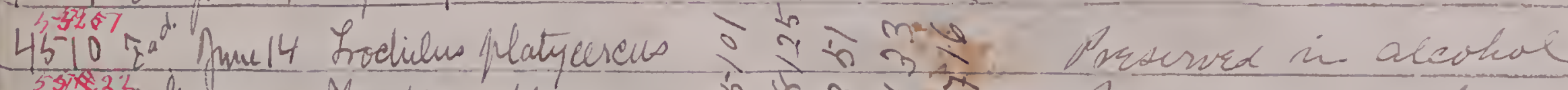

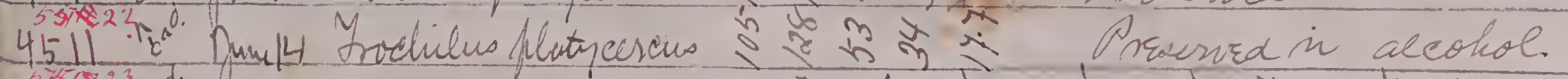

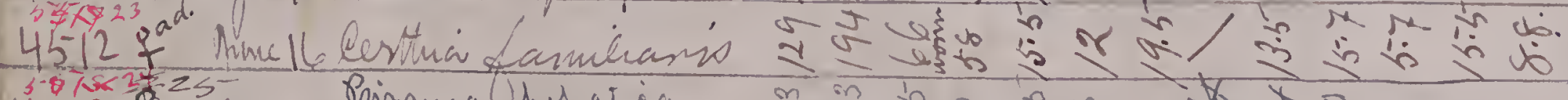

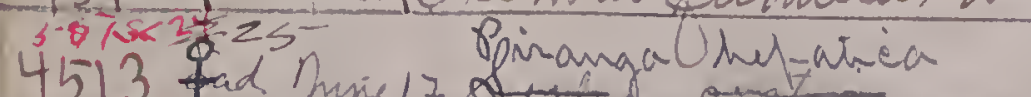

4513 tad 7 miel7

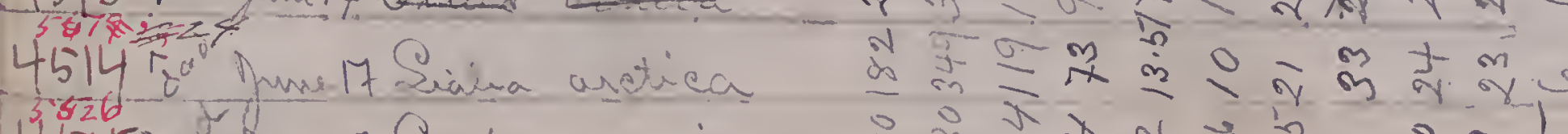

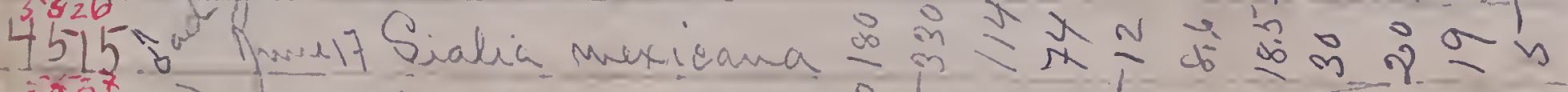

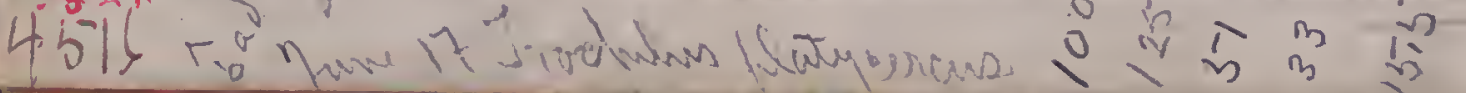




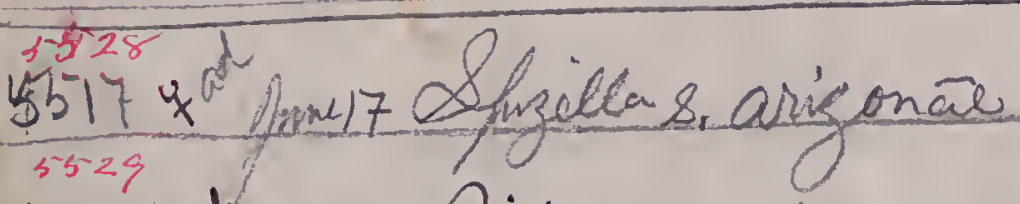

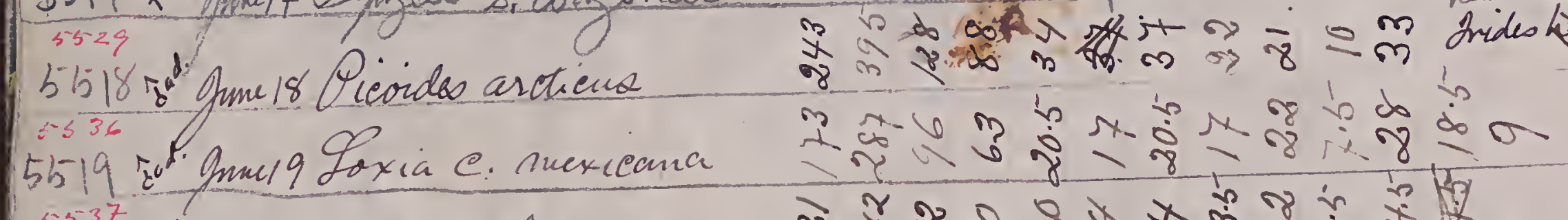

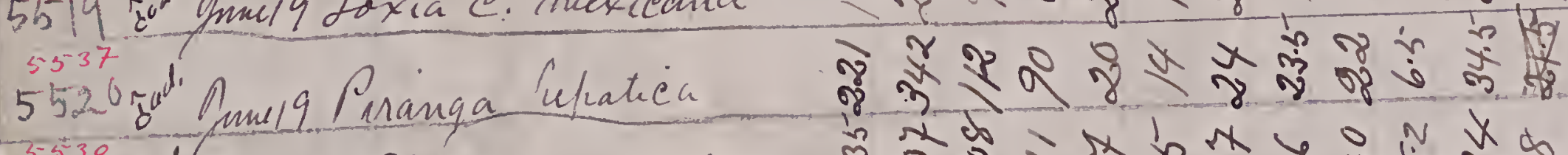

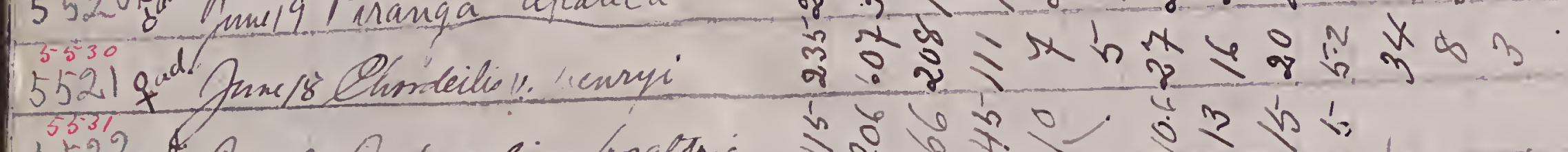

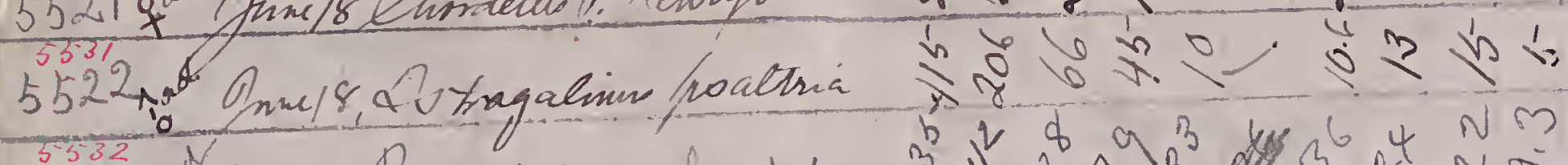

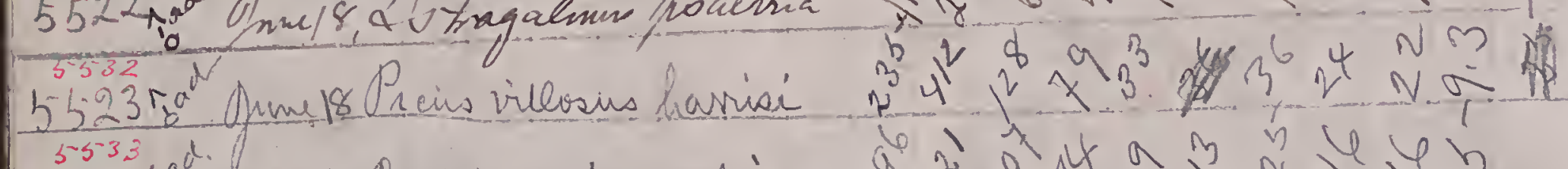

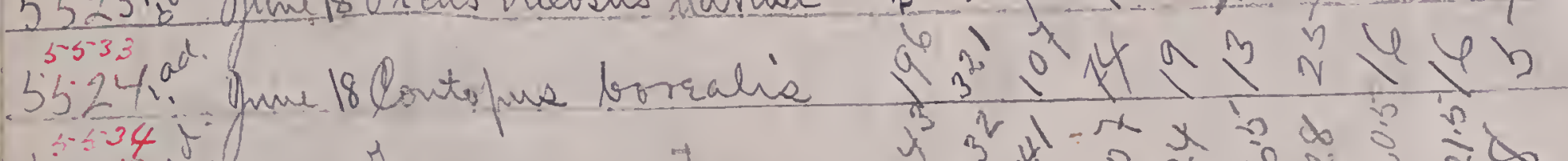

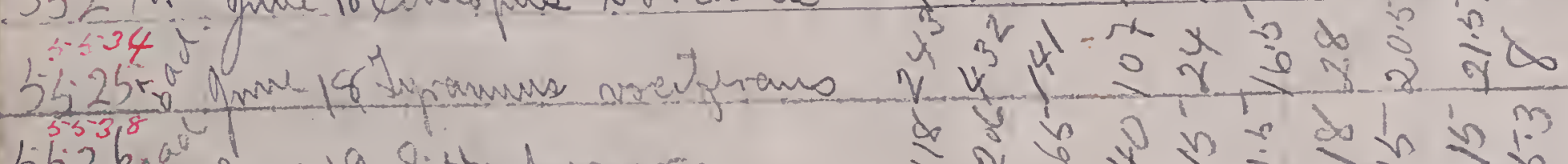

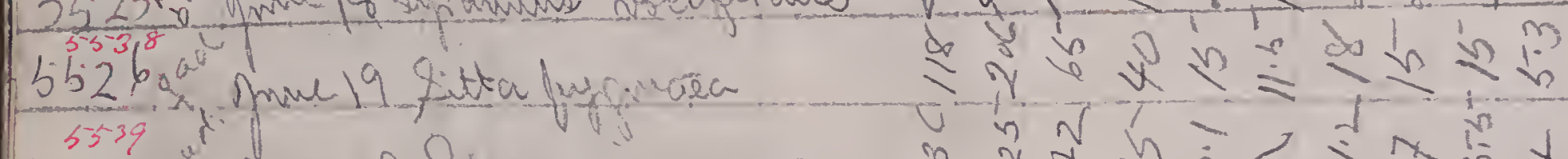

$5-399$
5527
$5-20$

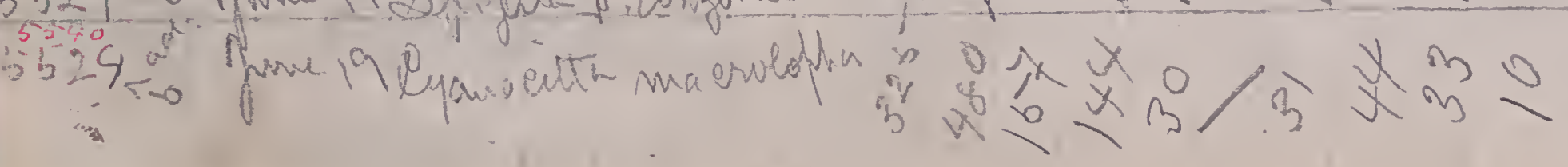




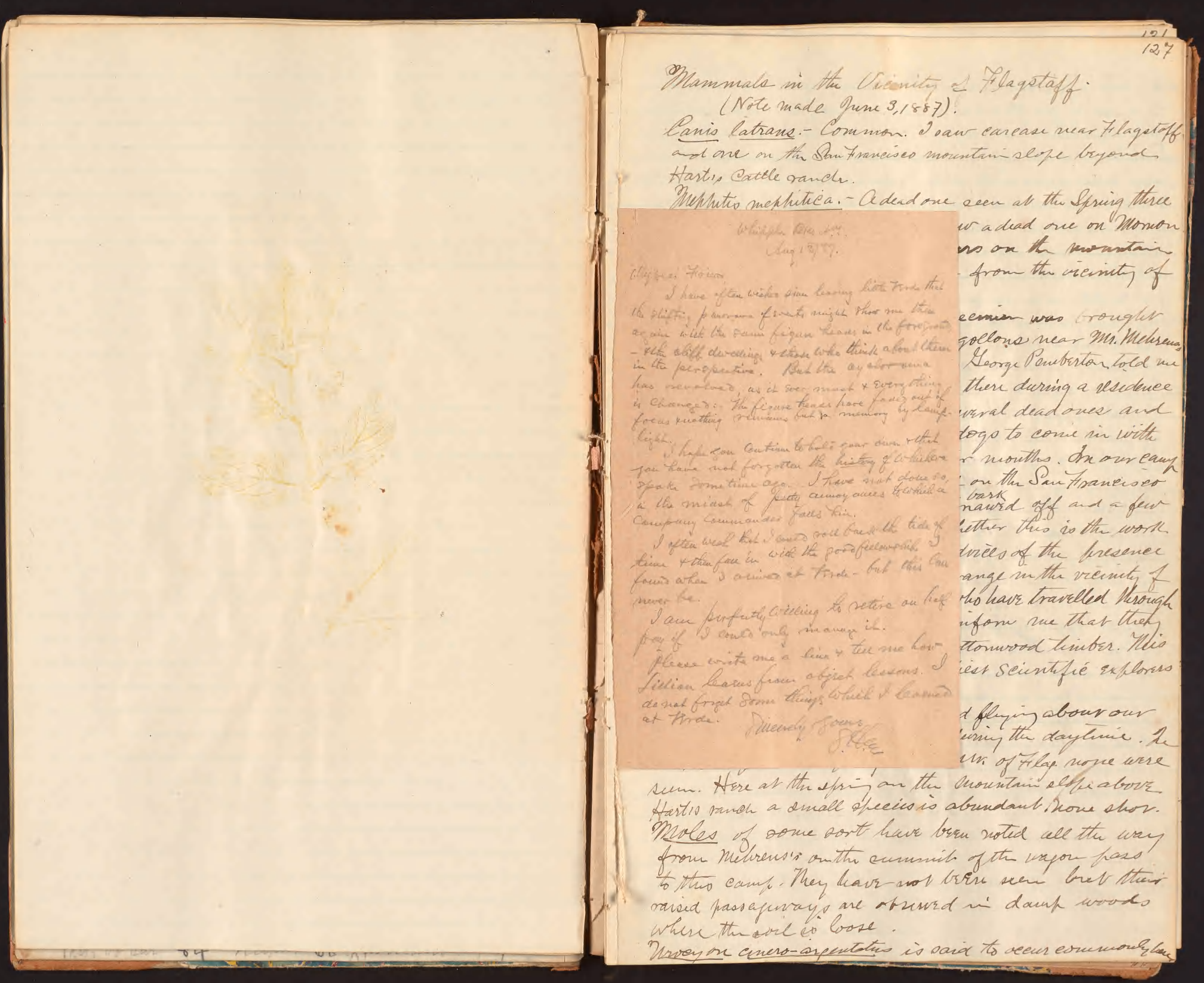




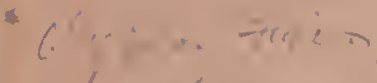

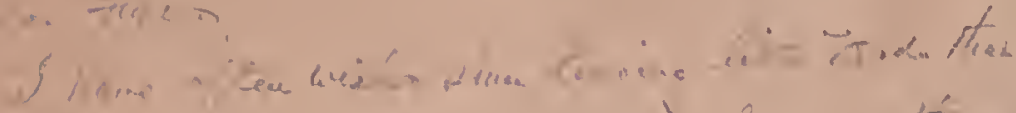

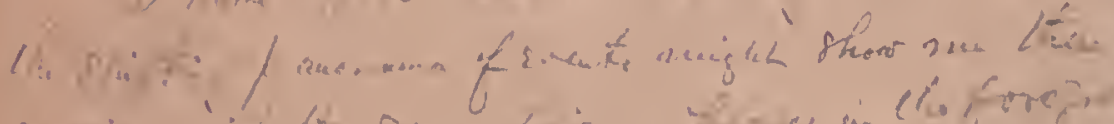

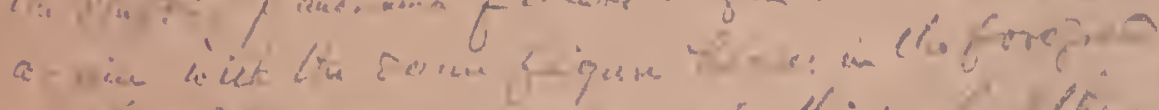

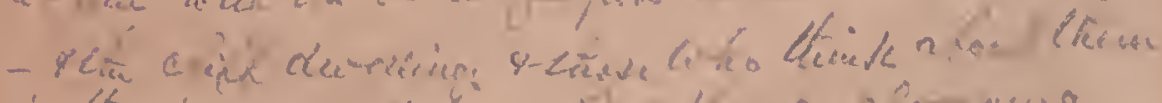

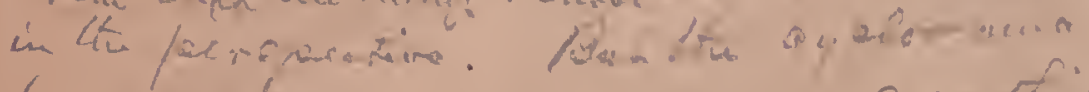

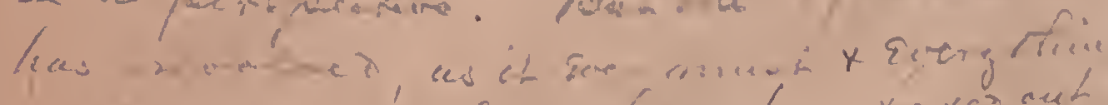

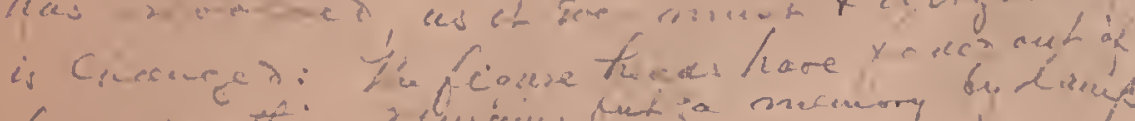

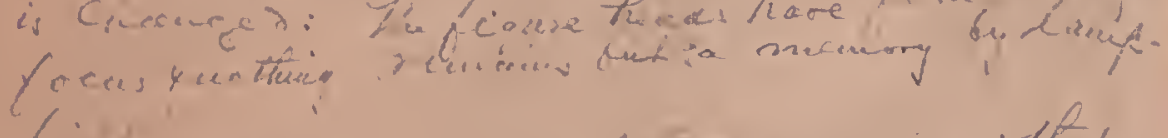
Yirks.

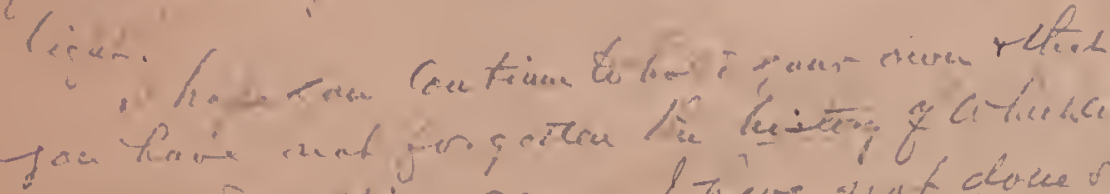

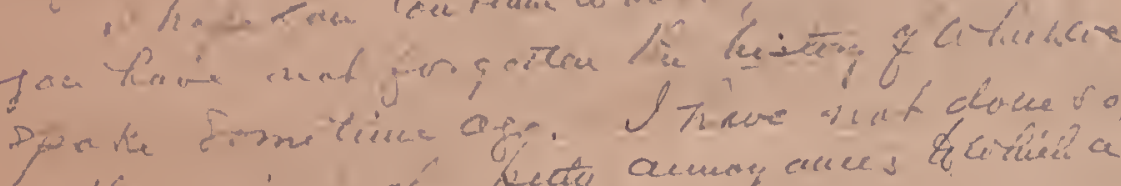

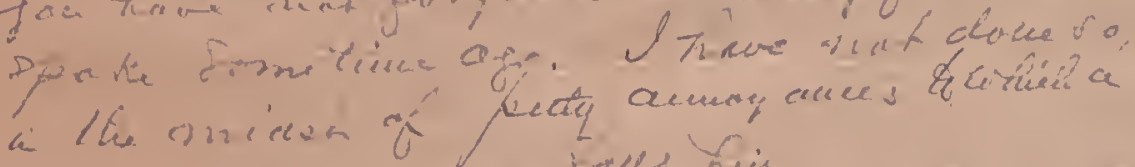

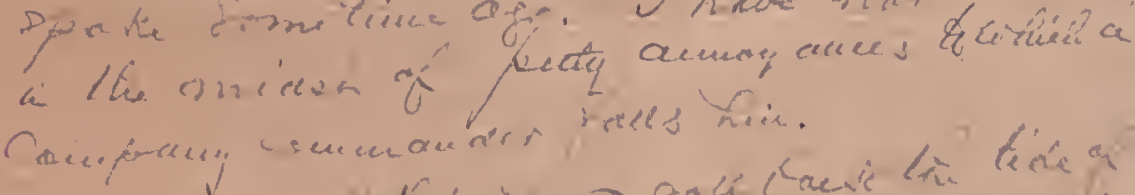

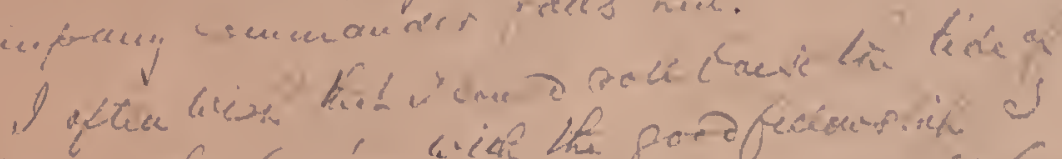

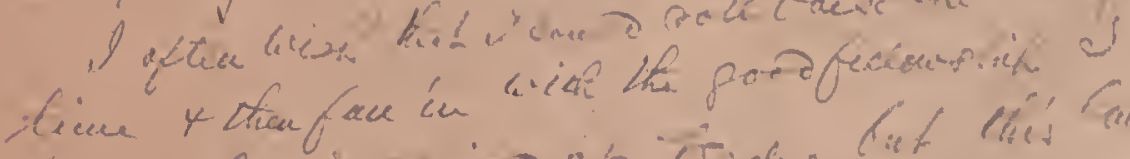

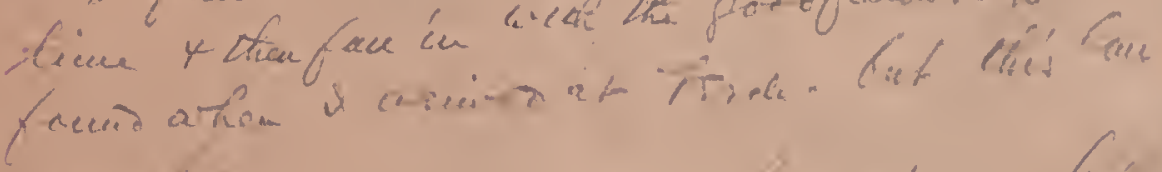
deer, ve.

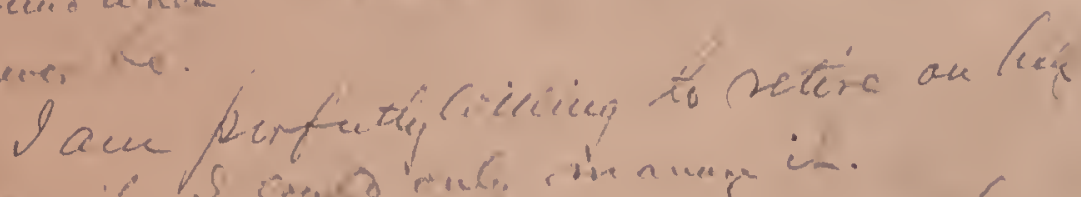

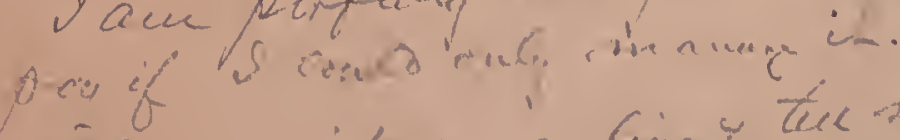

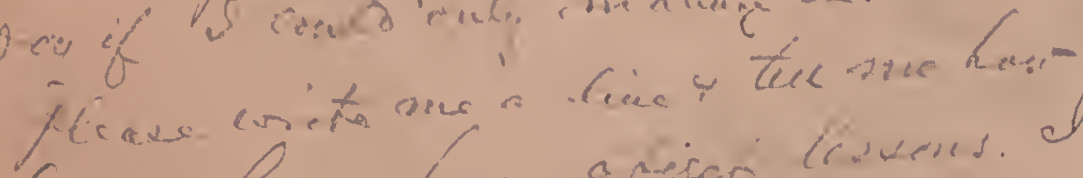

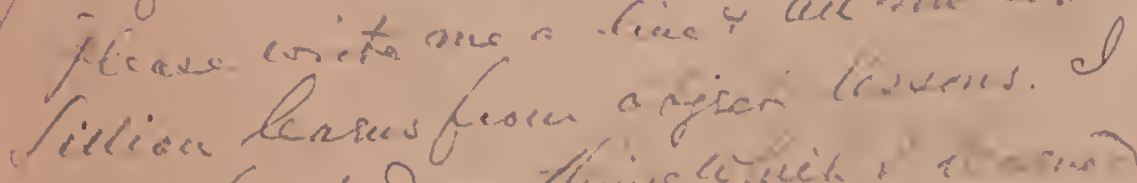

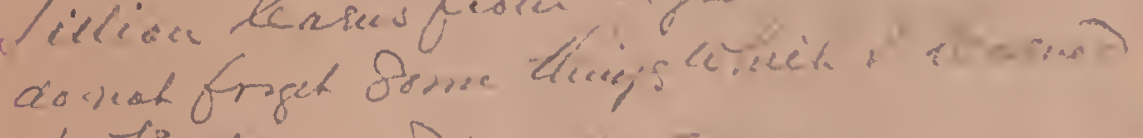

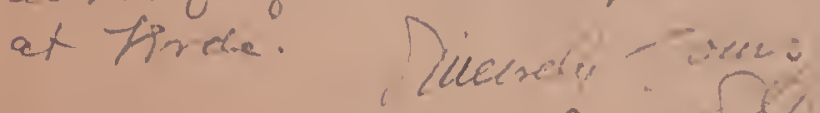


127

or

Flagutafy.

(Note made Thu 3,1887):

Canis latrane.- Common. D saw carease near Flageloff and one on the San franeises monetamislope bypond Harti, Cattle ranch.

Mephter mentitica. A dead one ecen at the Sfrina three mites Xw. of Hilagstapfy. I also saur a dead one on "Monon. Lake. M. interrufta also securs on th movastain a speemin was brougles me from the vievisty of Fabotigf.

Mplow-hairid Poreufune - A efeenien was rougler me from th Summit of the Mugolons near Mn. Helerena cattle raveh by Mi." Bill" Clift. Heorge Pentbitar hold me he had never seen a hise one there during a sesdenee of zevaral years, fut had seen sevral dead onee and it was a common thing for dogo to conie sin with horeufini quills shok in their nonths. On ave eam

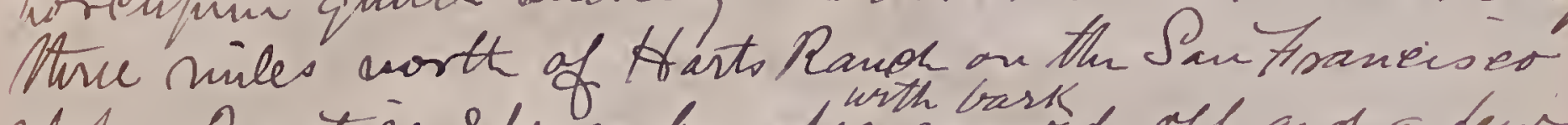

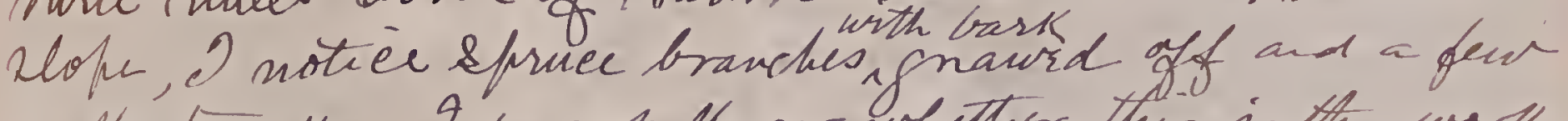
Ha tinulks. Ids not thow whetter thes is the works. of Porenfinies ar not. If have adviès of the linesenee of Porculinide in the suogollon gange in the vicisite Pini Preck Sietlement. Personswho have travalled Hisough the valley of the Colorado Chieito infone sue that theh are there quite esmunar in Collonurod teriubr. His aprew with the aceonts of the earliest sciuntifie Exylorss. tit repion.

Sato. Al large pecies was obsersed fluying abour our - eamp 3/4 mile cast of Flagptuff dining the daytinie. In

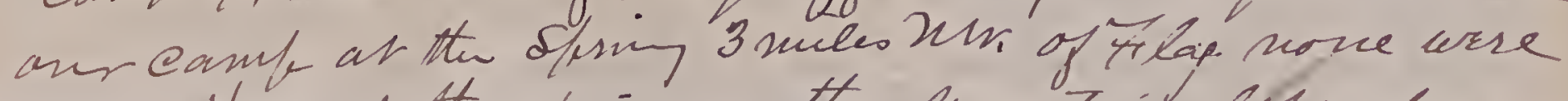
sum. Hire at the etrin an the Anountain sespiabove. Haitis ranch a dnall ofeceics is abrendant inowe shor. moles of oove oort have bran noted cell the eray from melirens's onthe cunnith of the vapor hass to tho canf. They havenol bers serw bret their: raised passeginays are ofsursd wi daup woods wher the arl es loose.

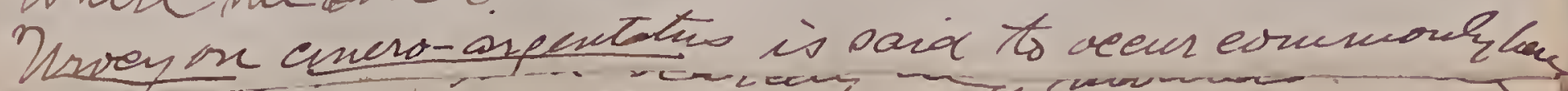


128

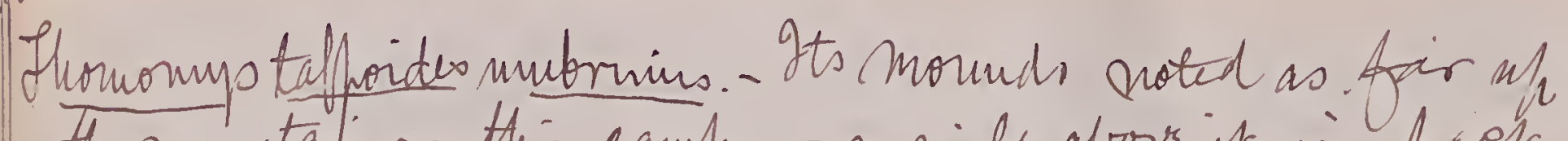
Me mountati as this eamp - a nill aborr it, in fack.

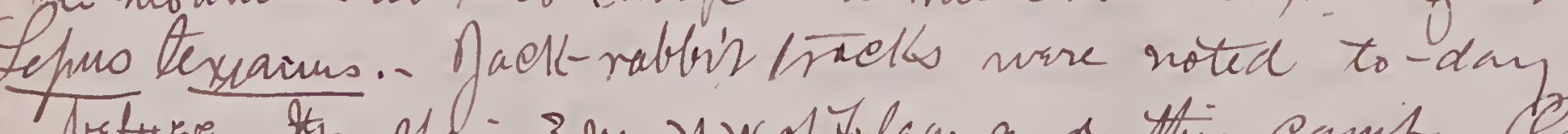

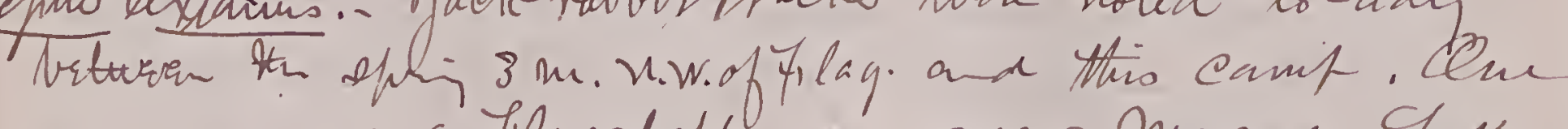
was seen near Flagetaff, on near Mormon Cake cone shor at Helerencid and others seen there. Sloettmen gan it is varry nunsual to see then an the monitan Seareit of grass, mupreedented, may have drivan them to Midrat unvord in searoh of food. The one Rilled at hand it geoved and fas. Sone stoek-Muen told me the thal vever bifore seet a falk in the monteño above the lim of jumifertres.

Darnäens maerotis montanus. - Hraeks abour our camihen.

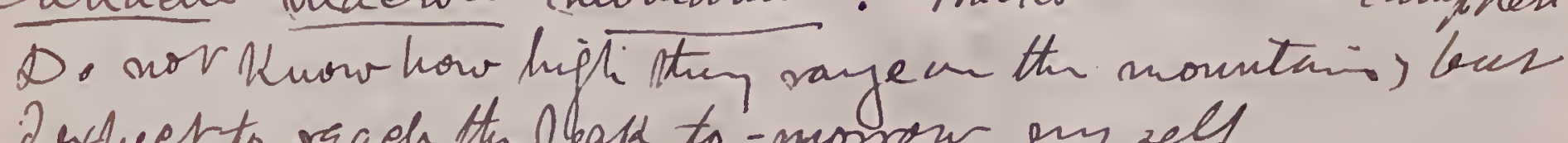

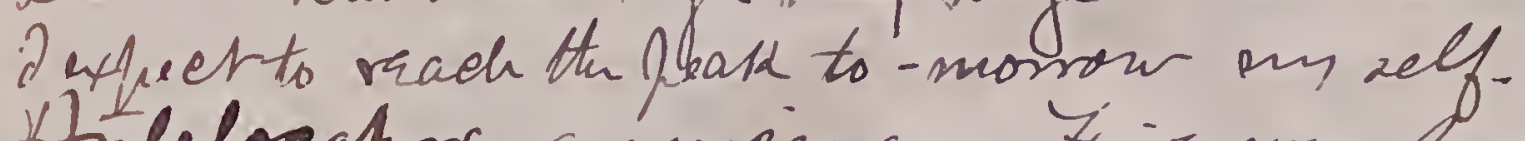
Hnlelocapre amencina. - Fir core Lassed neas

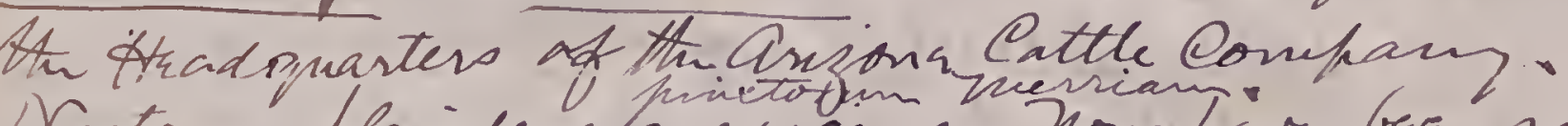
Seotoma floridana mexicana. - Moxe liars bram seeng but

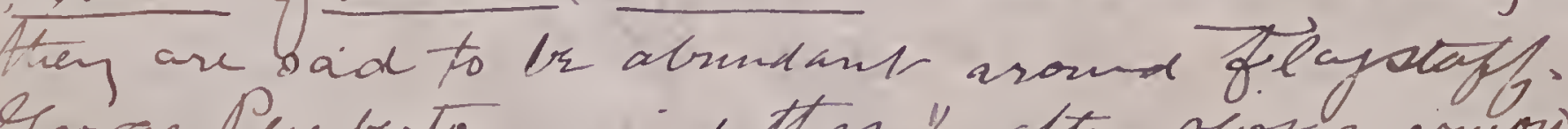

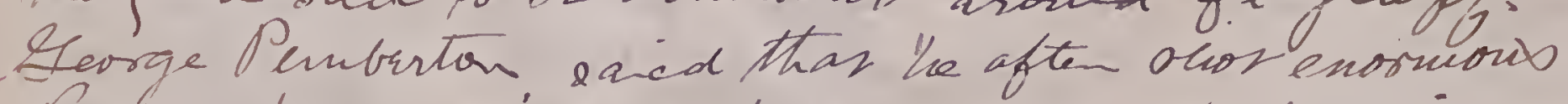

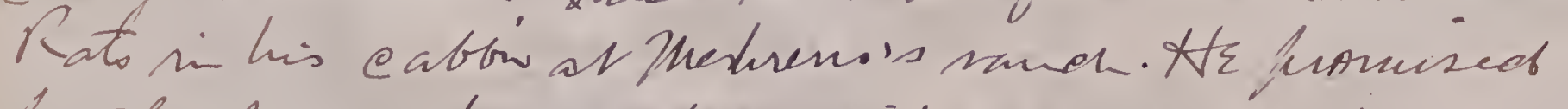
th shoor on for me bir did nor do sos. Tomian inidrititatus. - Hound commonly frow Whetreniss ransh to viry near the wher limis of the hines. We are now encainfid on a pary frist where the lime thibur ands and frivopmec \& aspen tath its hlace. The ufpersuont pines, thouph of pame ofeceies brein to brand clore to the proind. He have nov get reen this chifmunth here. The lasts mu noted wak a mile brlow Atarts ranoh.

Yanias laterahis. - Sem as kight as wr hov yets bran. The firit wre found a half siule abov

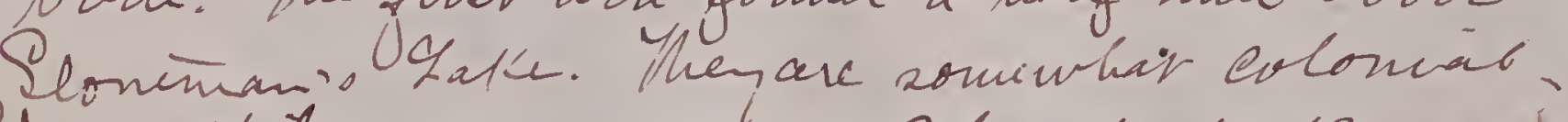
Sfernofhilus grammunio.- Abundant al our eanh

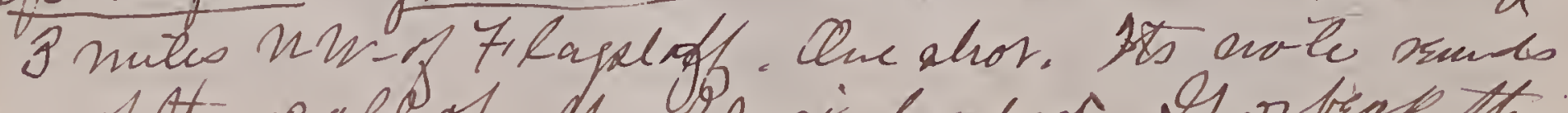

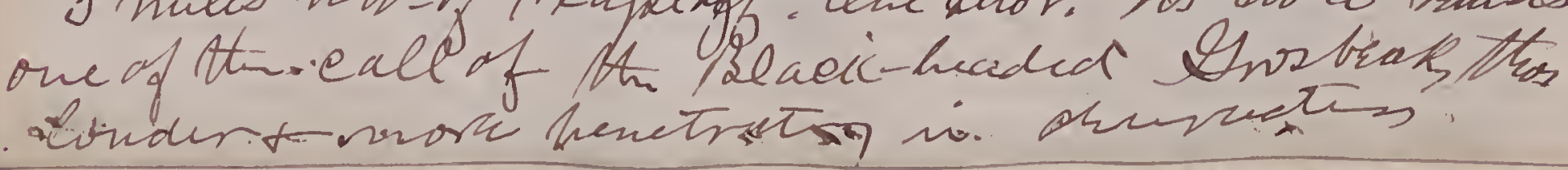

Whe heard olose by a dufmunts "snicker" is heare Whieh is enaudible of a thort dralanee Hlap. 1 sew some of ayp in a finc-true. I walked to tho ofor at same a weat; when. I had clinbed half-way uf the oumer, browin to br, this fquirrel

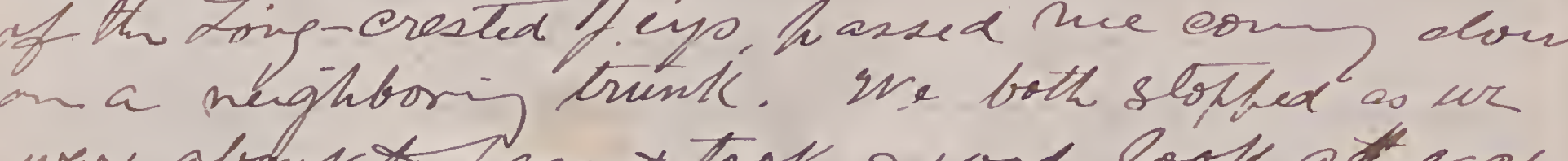
ware abour to hase $r$ took a jood look a each other. Ifelt e enfreme disighet ot my. Taxederni- cal maveto as I loosud of the hivis oreas

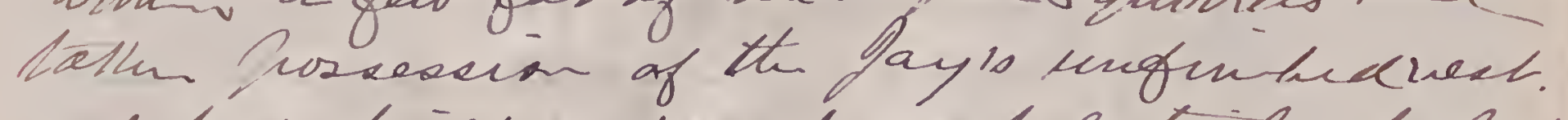
and had biiet a round rest ritirily of clunts

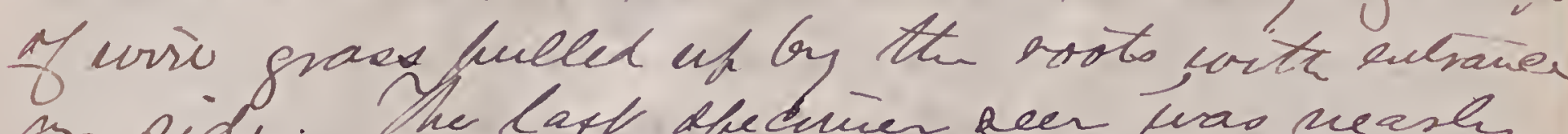
on side. The last sfecuiven deer twas neash at th Arizona Callle Confian's randel. Ithij,

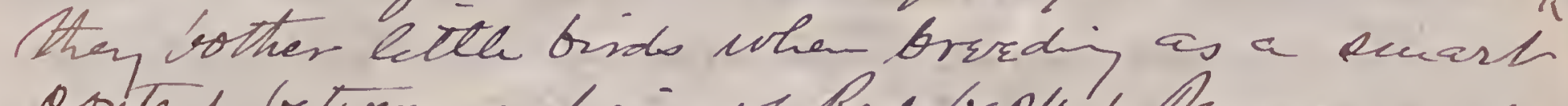
contest brturim a kair of hed-backed frmoos a d Siabrte nas ininessed ivear th Nimum Yalk. The Cal. Woodzencer of Cbrit's Pinu Squirel

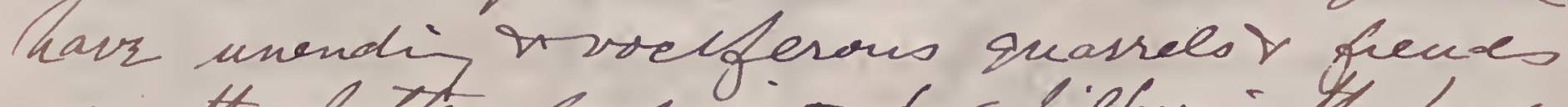

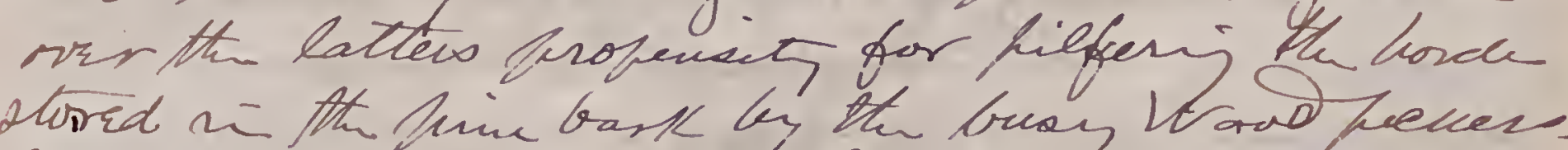
They ocold, brrate $\alpha$ brlabor each other rounch,

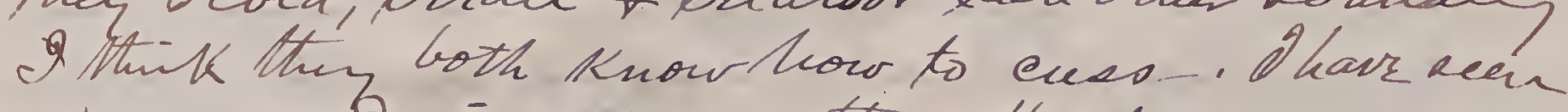

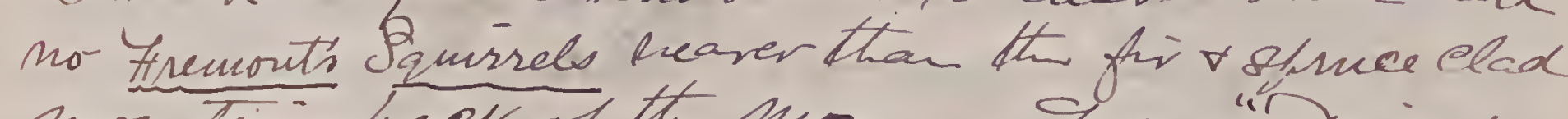

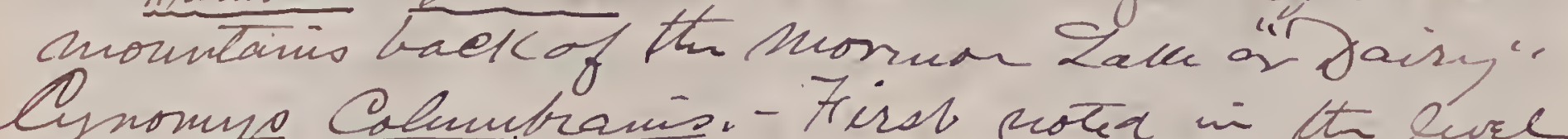
flats arond the rhomin fake. Thence to the

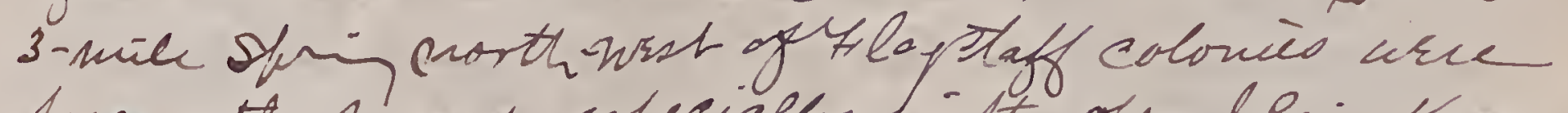
Arewenth passed, cofecially hist ofen blain thoun

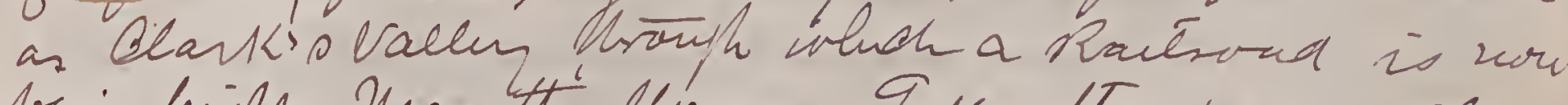

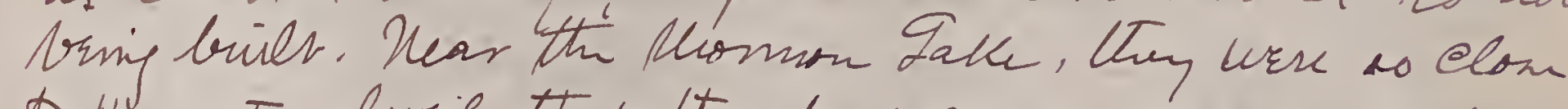
of the nater-levil that they had constureted enormoles nombs of considuble hujtet 20 or mone fut wi, deanites while Atrore lisigh a rodh, mese rece of the Lalle hax scereel any kuound atale. 
130

Que colony near nommon Lake hira rigles in the

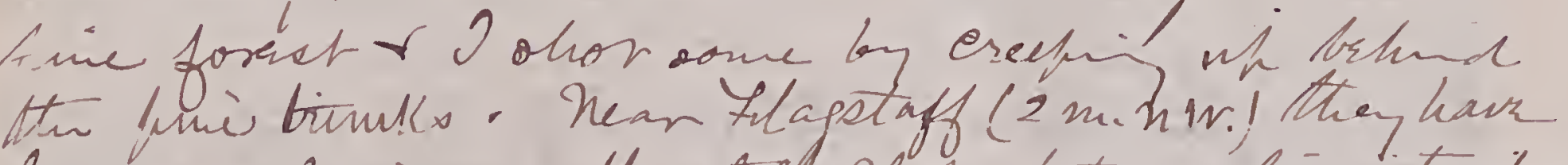

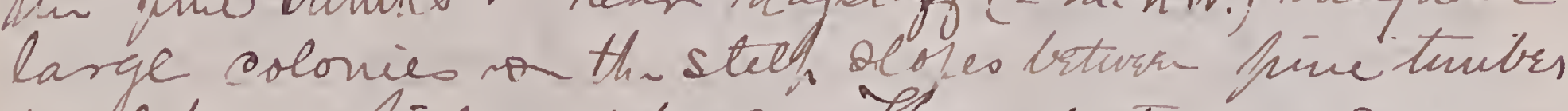
ot culitivatid fields of barly. They destrion a snas

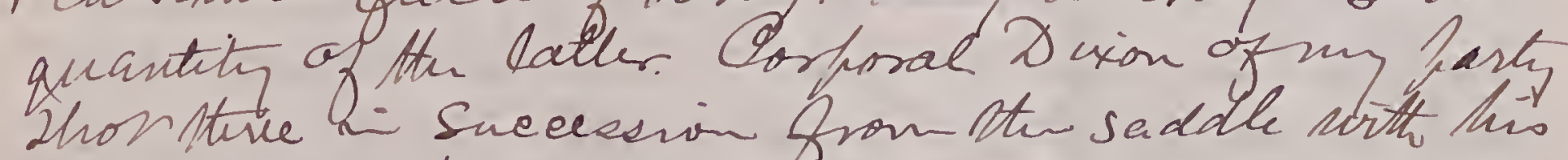
carbini. Irefond Atin farso exeellent in flavor for wh ate ox all liraised them as an artiée of hiet Goolonn' linin in a mok

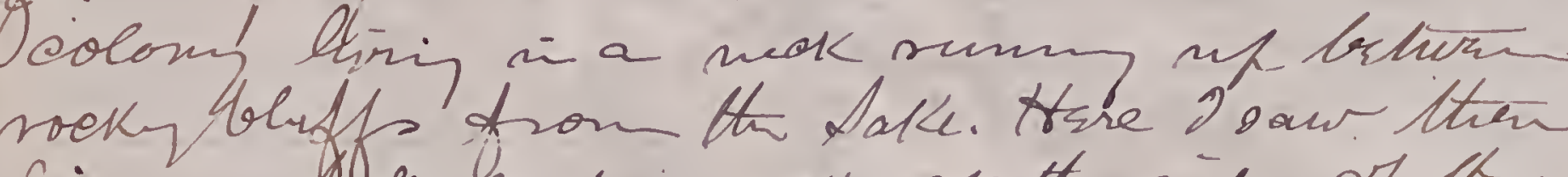

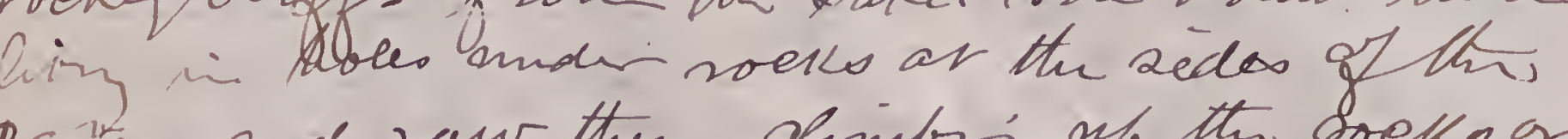
carion and sour then chinbs m/ the soeks or

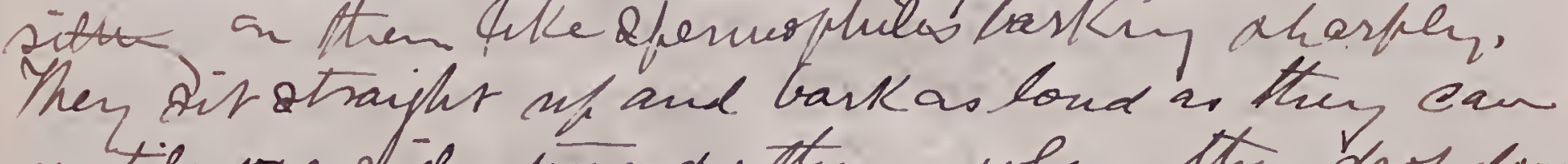
stil, upe shides sowarobs then, whem thy arof clous mi tis defression in their suonde or the extraicer to their lourrowa dhow There are commonly sevand burrous in each mond $x$ it is a common sight to see cure spinj

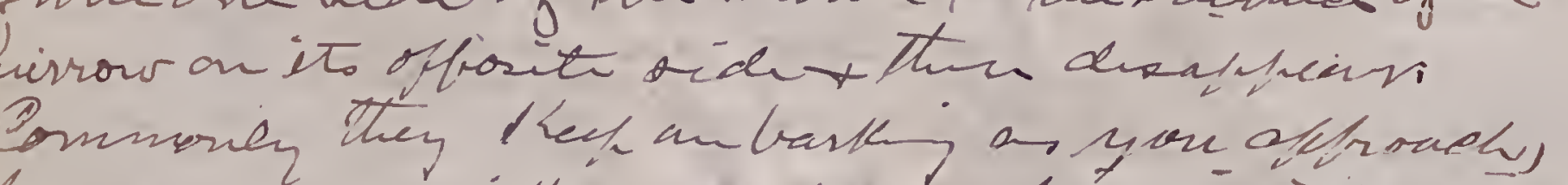
but graduale with draw from traur in tio juot

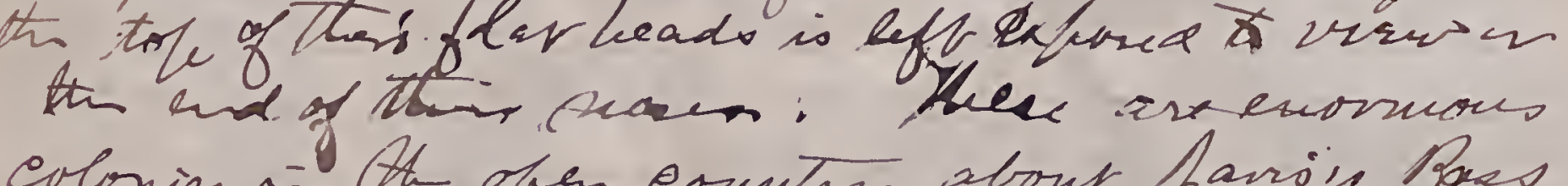
colonies At ofen escintry about farios bass

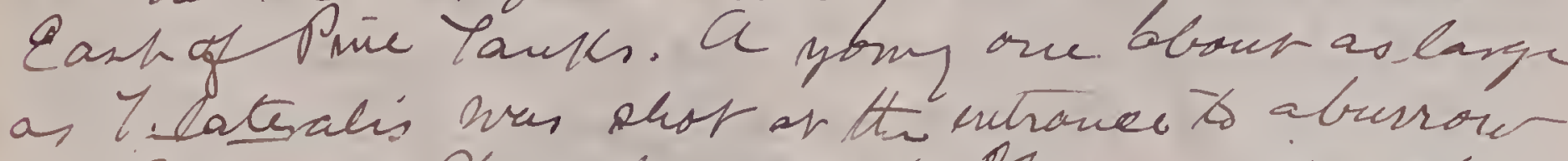
as Y. Lateralis was shot of the ntronec to aburow

Putonins. A Weuse was ohot Dime 20,1886 at the

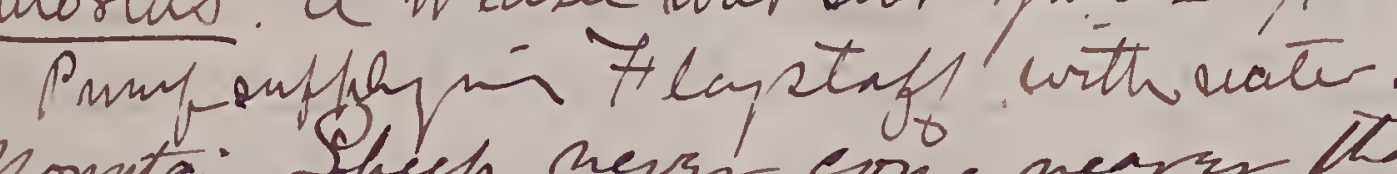

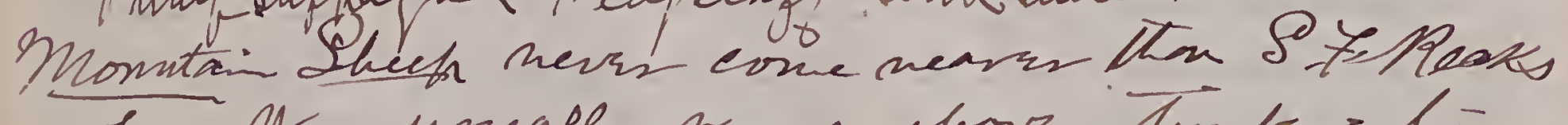
where Als y unally rampe above tindtas his cus a ron mar who necompanid flis.

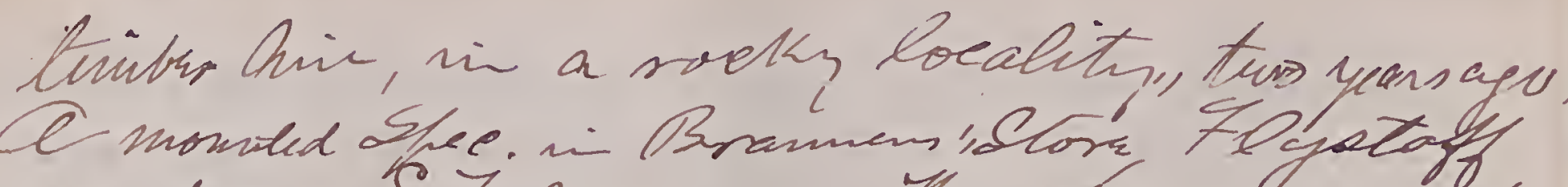

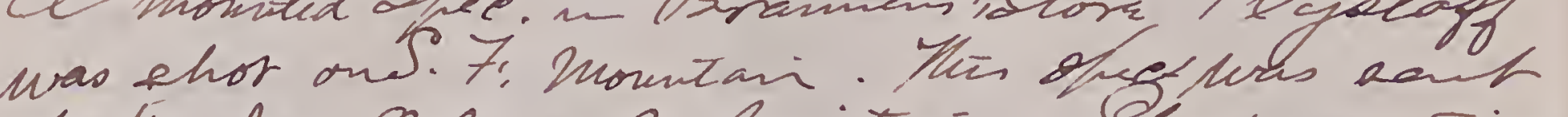
to th nenterleans is fusitian. Shap are elide

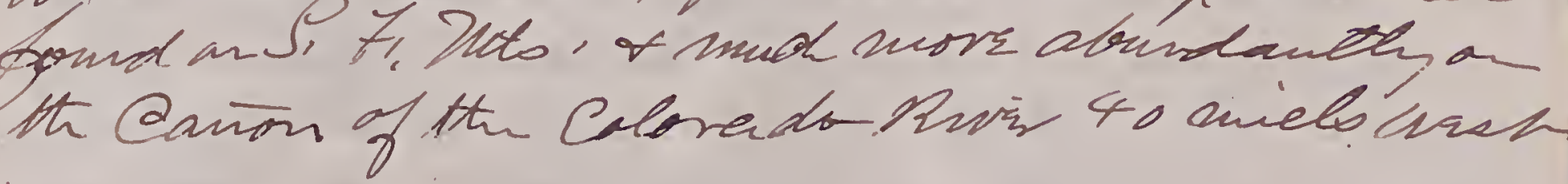

Mammelos Mrids Sen- on San Iraneis es Monntain, while in eamp an N.W. Slope at the S/ring, from Astur striatulatus. - An nimsature shecinien whath young of year startid from an as hen thisket was seen Gume 3, abour b- niles bilow this canh in thame forest. Austher aduler uras ecen the wer edge of the cedar dorest below Sonciman's Lakeon Drtany 21 st. All wore too shy to br shoth

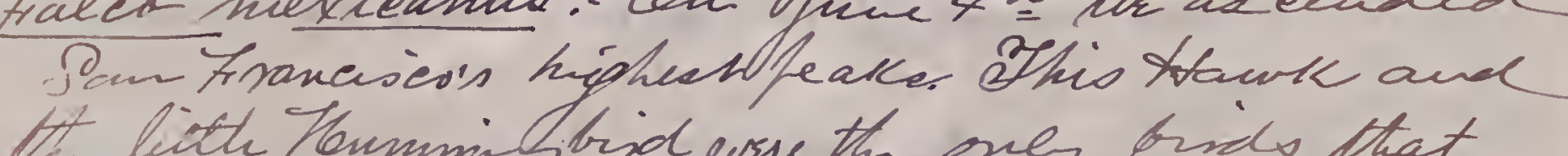
braved the fueree wind and esed of the sumin Both glew over the sumits. Onneo dorsalis columbramue also sanqed ni thin hijhest slanted

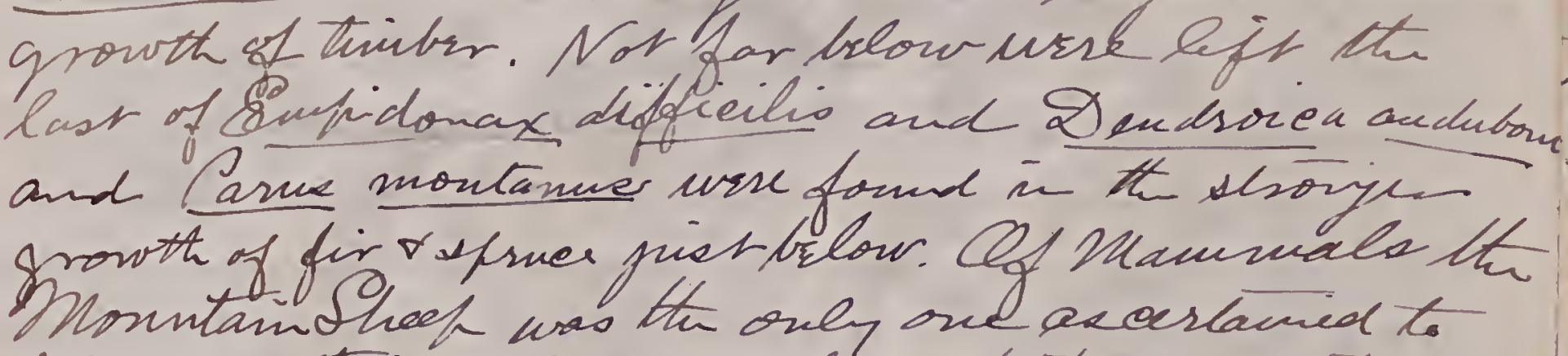
his abov thiorir line. We found the trades of turo os

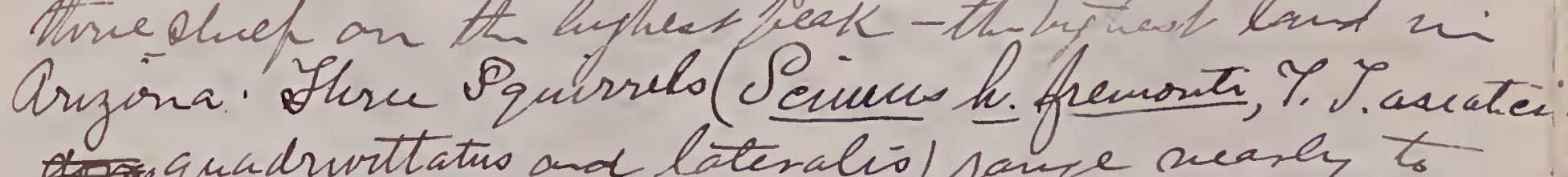
anadrunttatus and lateralio) range mearly to th last growtit of tallish of meec trfore revel; the

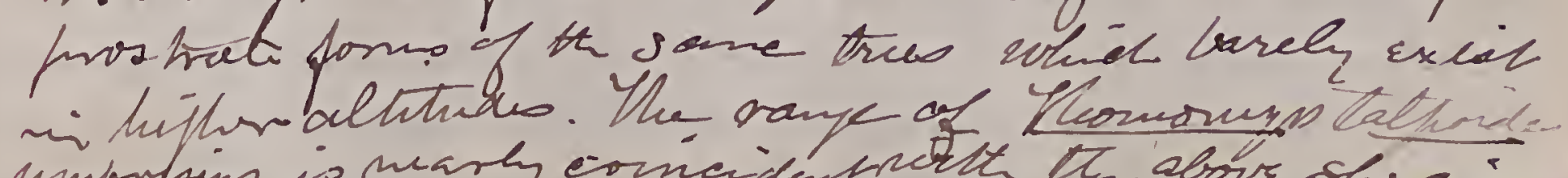


132

A anadruked leaving a ridge of loose earth to mank its conrse wherevar is burrous, like thin enole, a shear of which it conotless is, also pruge vkwards towards At hiahesh forsets. Dees now ase saming nh about 1500 feer above onv eamp, nearly to the finist of aspen

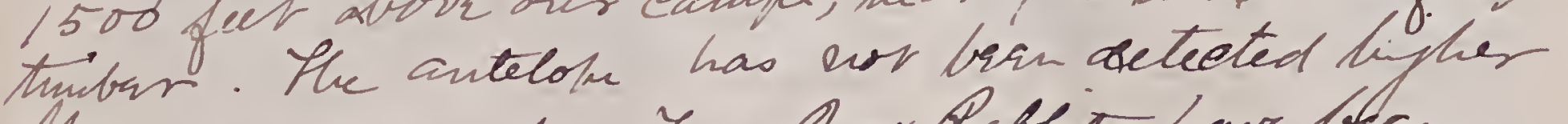
than onr canth. Hov Gaek Babbits howz ben. seen an the monntan. Yhe hijlest vas ov or faet above our eande. Other nutumalo noted on th.

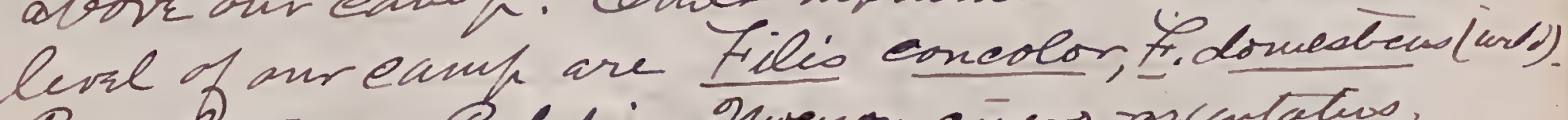
Cains Detravis, C. lufis. Wwejon cinero rajentatios,

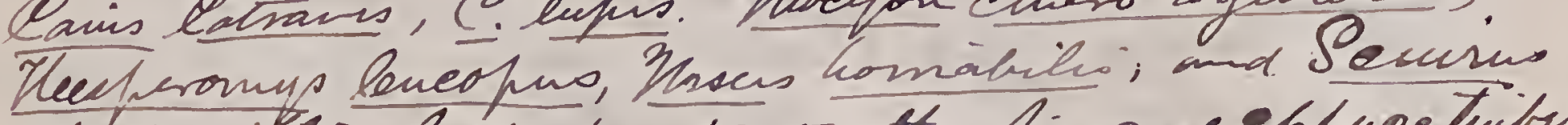
abirti. This last fere trater the fir and sfinuce thibes only as for as secutered fine-trees are foond. The highest that we have noted thin is in ourcaish

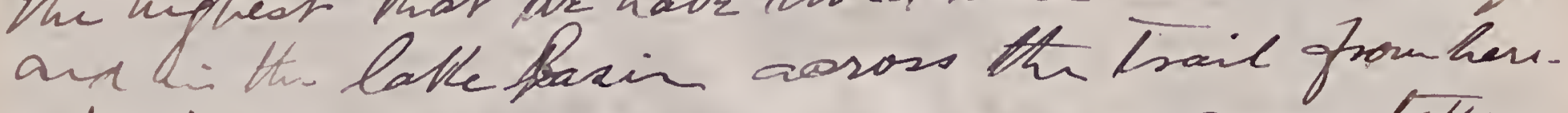
A four bato are seen abour our cann: sone latken. Haid nor boun ligher mf at sight, as do net show hour

Cafthartes dura was noted abour 5 niles brlow our camp. Genaidura carolina. - Ranges upuard thongh the asfen

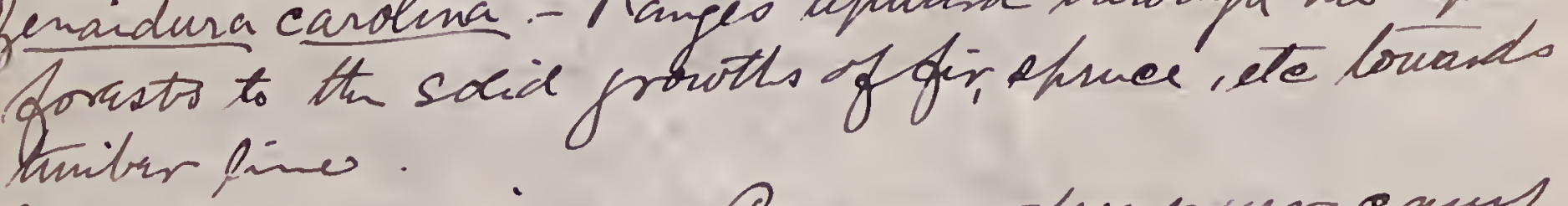

Seleloparo mexicana. - Conmon aloutrur cans. Ravies of as high as the asfen tuibar exterdo.

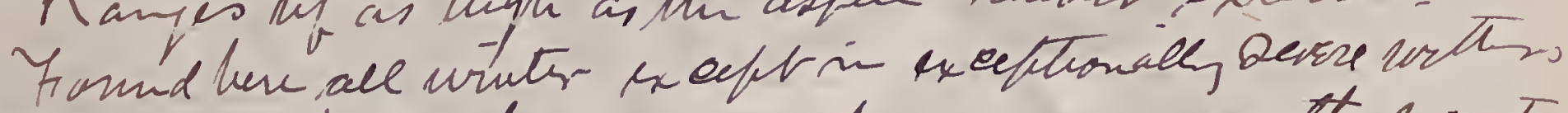

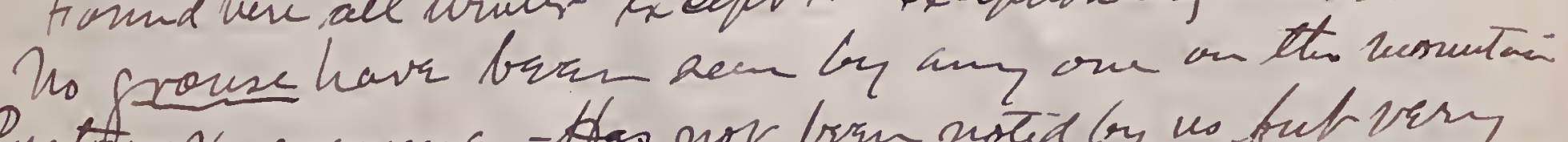

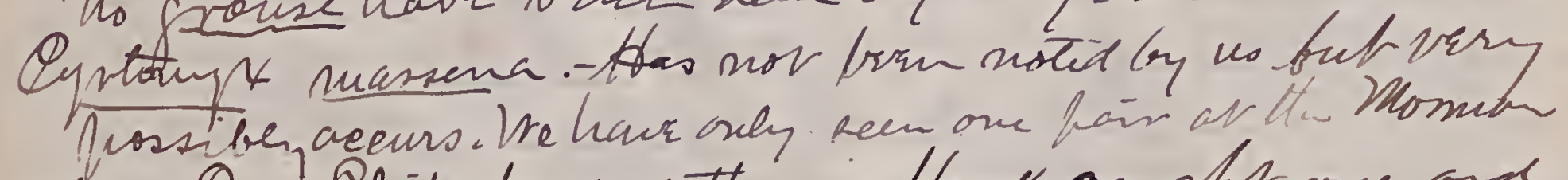

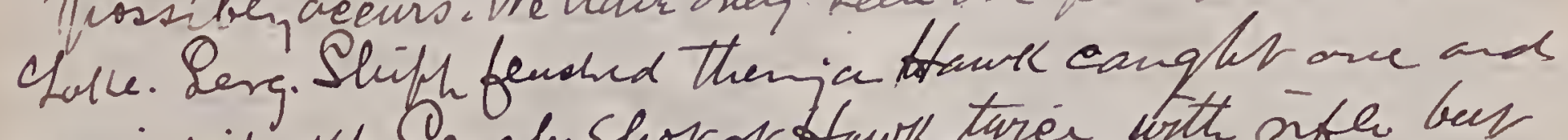
cavica it off. Dengl. Shov or tawk tare with oife bue

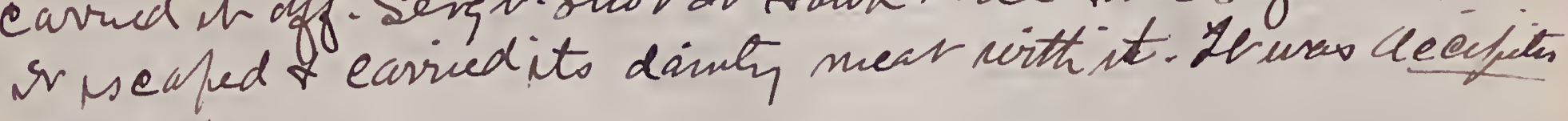
cooperi

Pringoides (Cectitis) macularion is the only nater lond found as this ailitudi, I fenoce une shor and

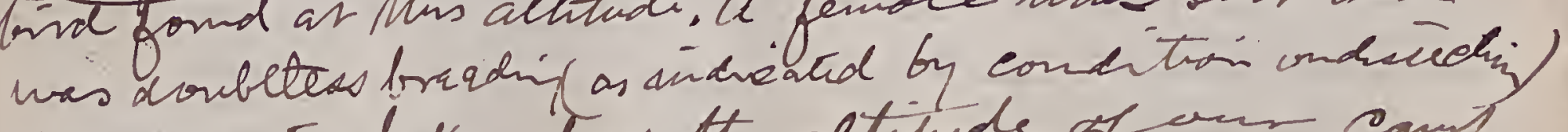
in a cratior Luke above th altitide of cour canth on the susnmis of one of the nountan:

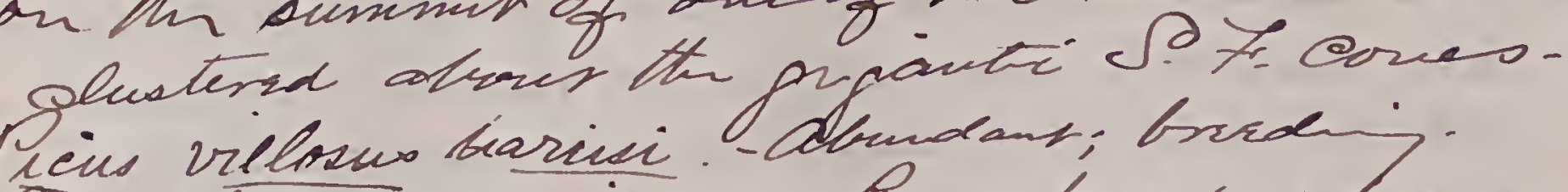

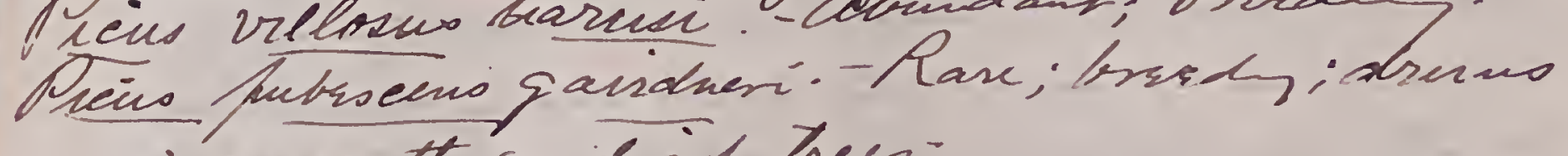
in exsonth, an dhaid trees.

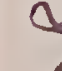

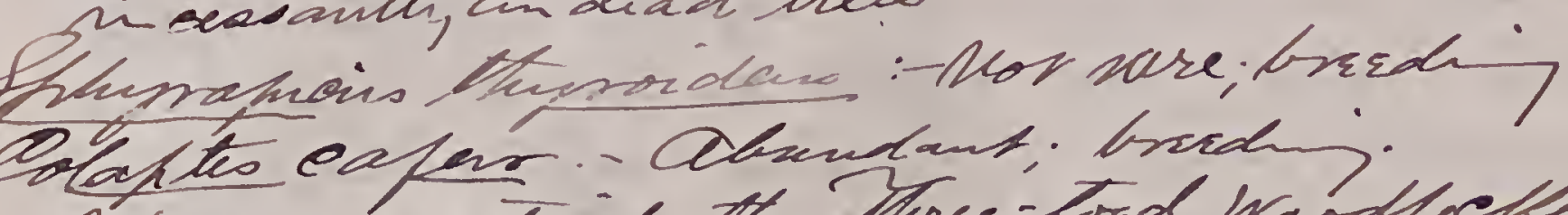
2 have not ciokeid the Buree-lord wadfollew

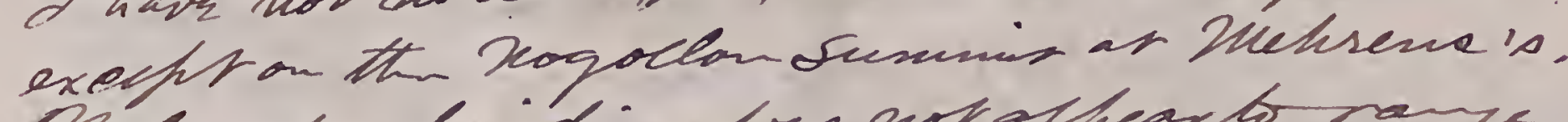
Melanesfes baindi:- dors not of hear to ran the

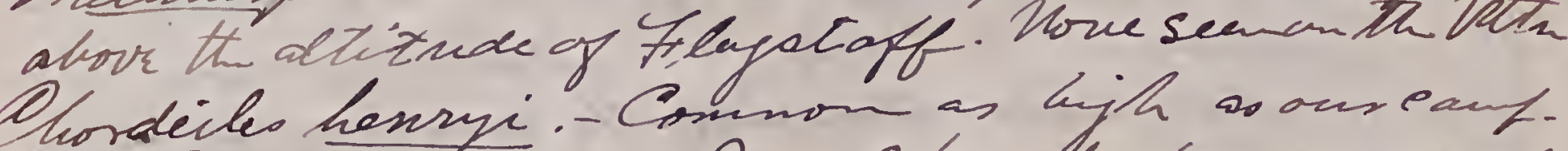

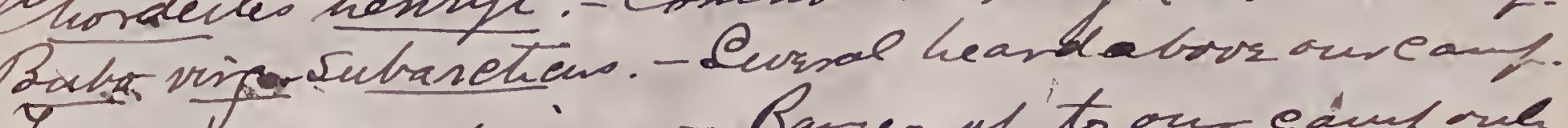

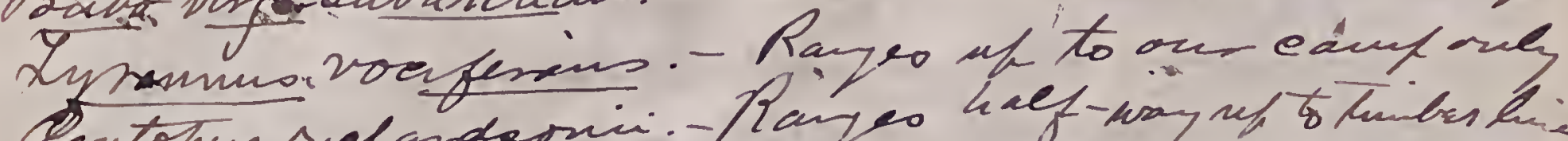

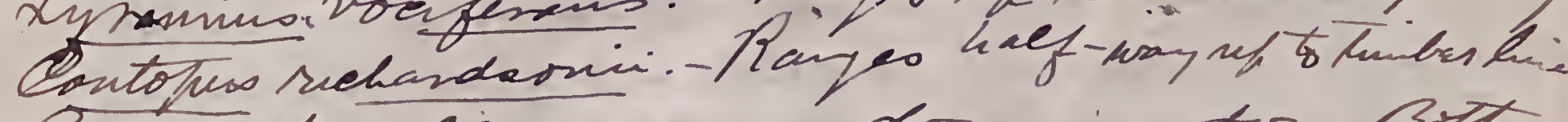

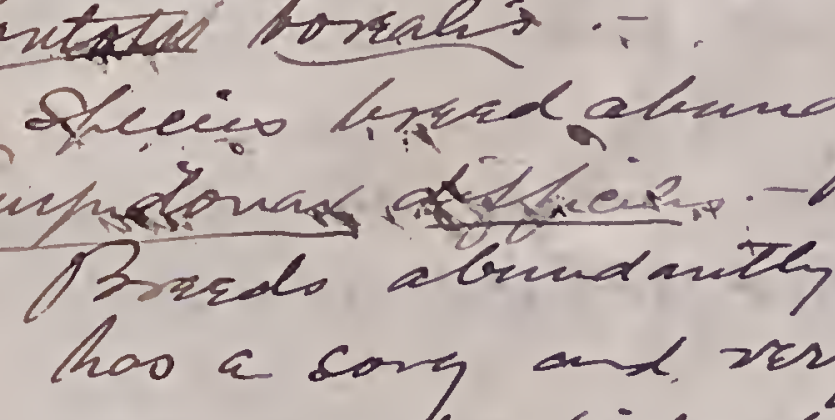
thi.

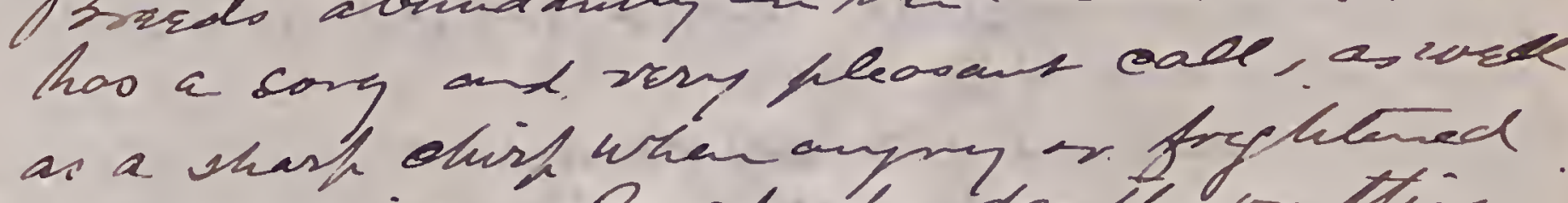
Pialia oneriecina. Mrads almed anth an this

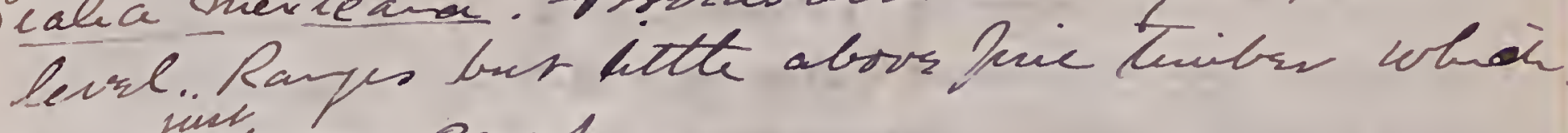
undial on eanf.

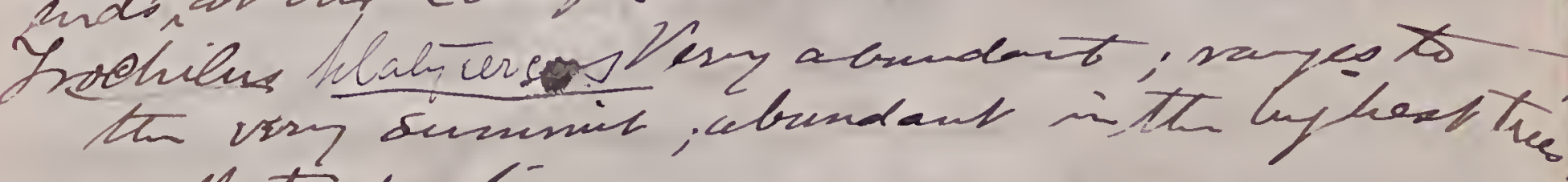
on the timbrar fine.

Aplocichla andubon' - Abundants, breeds as bith

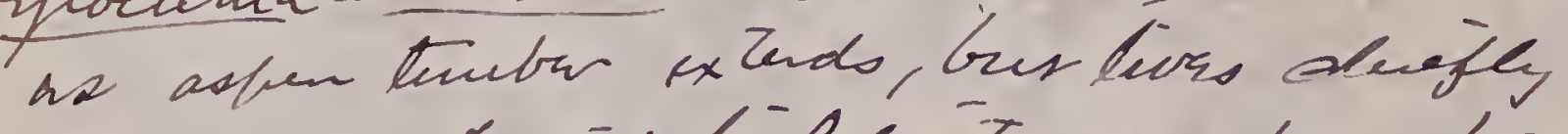

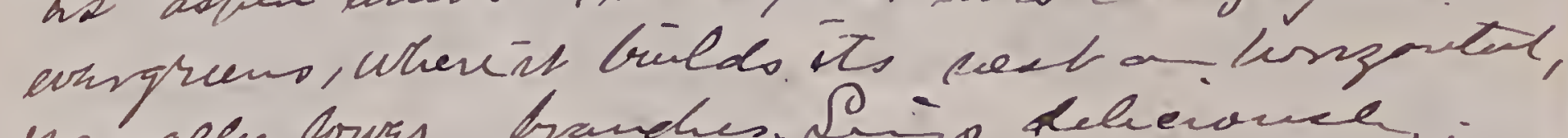
nanaely bown, brandus. Si io Reheionce,

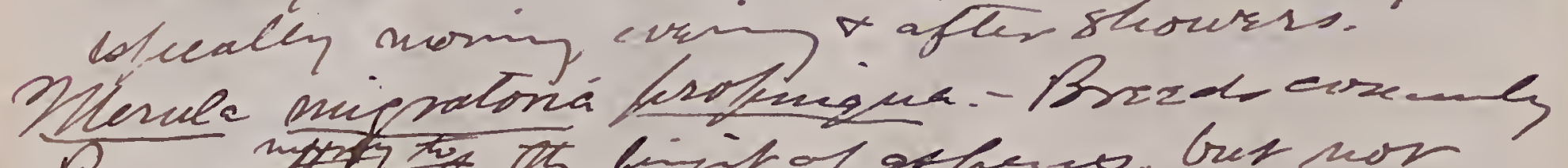
Rames th livitof asferes, ber nor abund ant abos the finies.

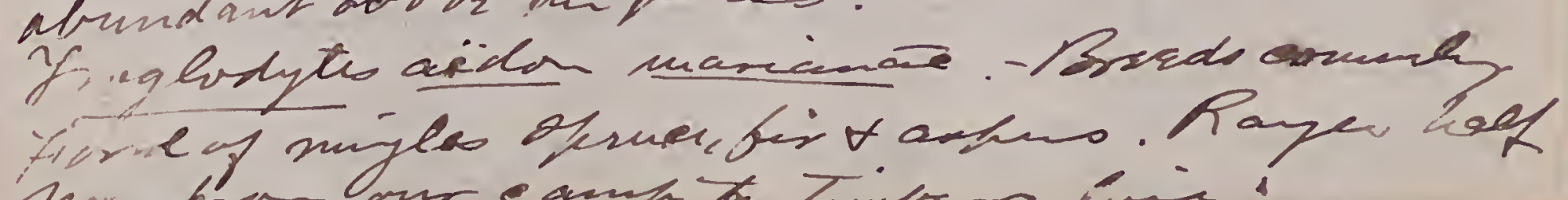


1345

135

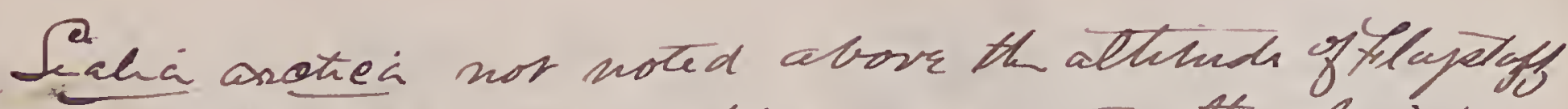

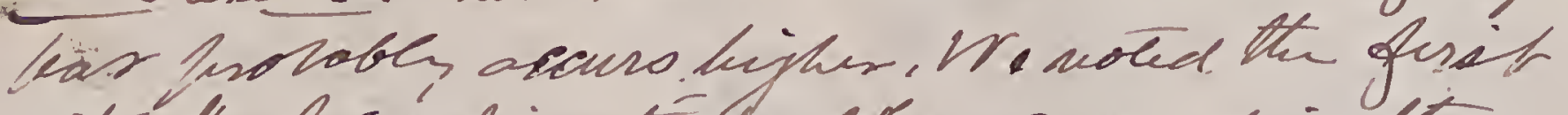
with: the fisis pine tunlon when as eendy the inonitani or fround to rese in the guruifers in the sealtered prowte of fries, whese the oedar ard tum forest are jomied by as

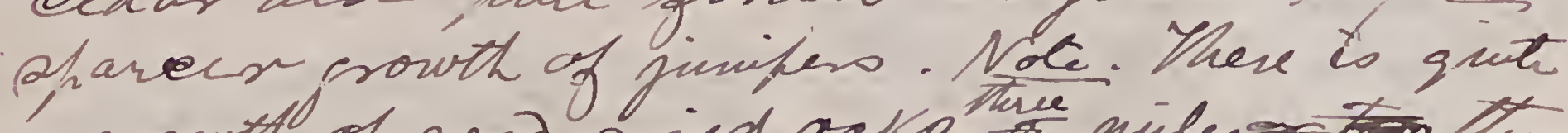
a prowth of goot-oijed oaka niles the in de of otecistagf - the hijlest I have noted them

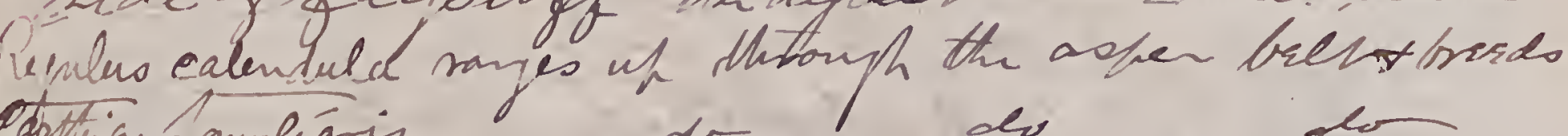

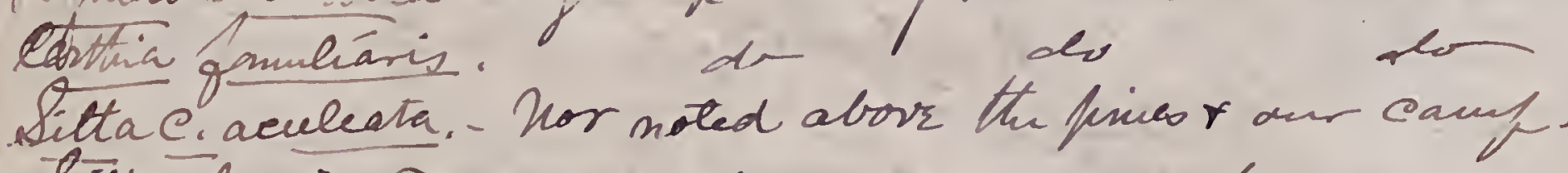
Sita ing jimata do de

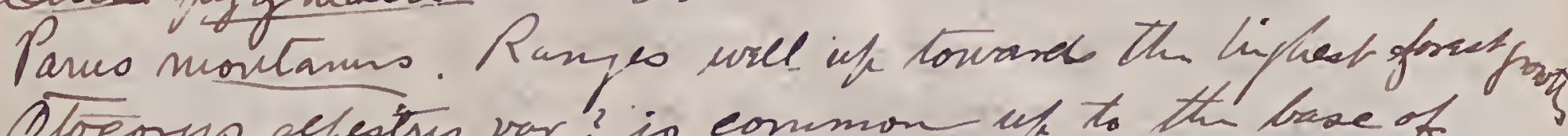
Qtoerrus effestus var.? is conmon wh to the base of the true cone of the conntry abors is obrioney unieuilid

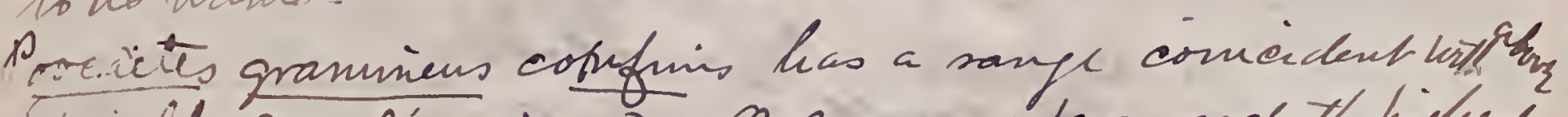

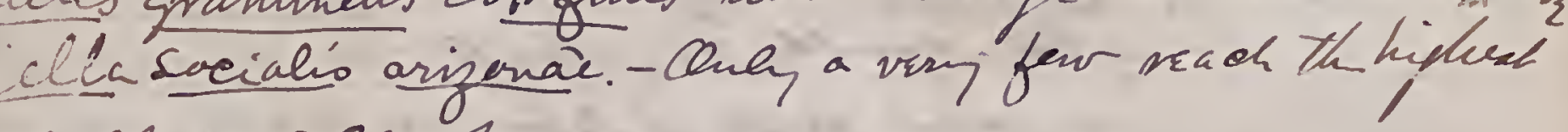
we or our canf.

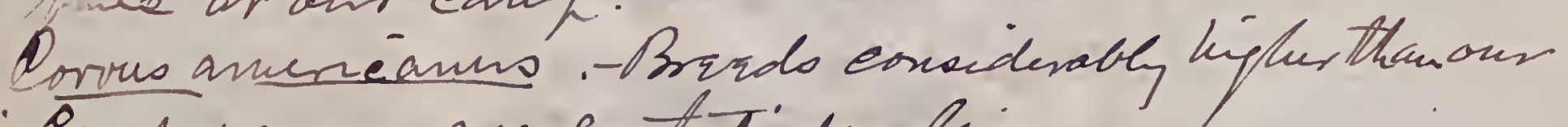
Campr vanges searen tos timbar Rine.

ieieonors culumbansss. - Ranjes doun to the ufter Inin forasto with ito you \& a family of yon wese

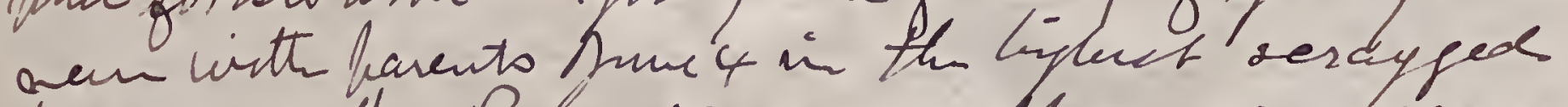

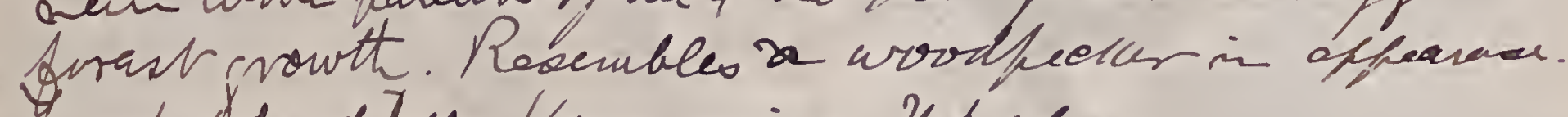
tand of dead hees. Vem noize. Mot aluy.

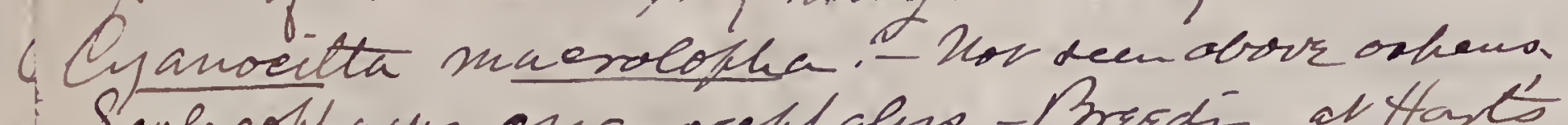

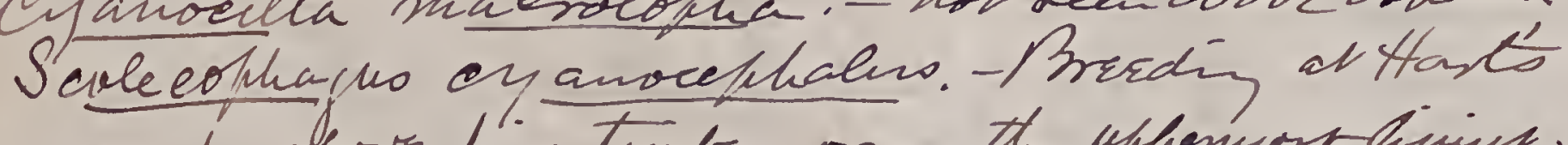

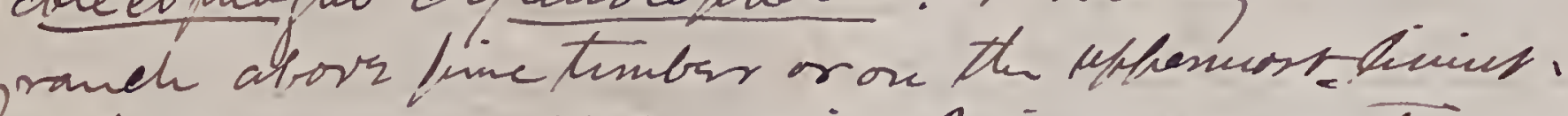

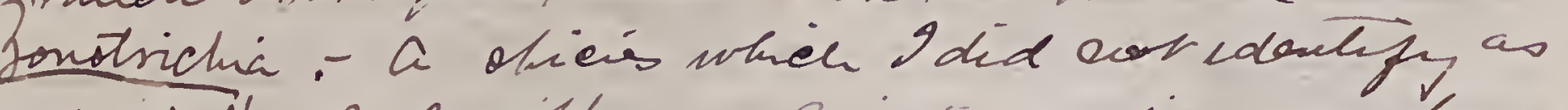

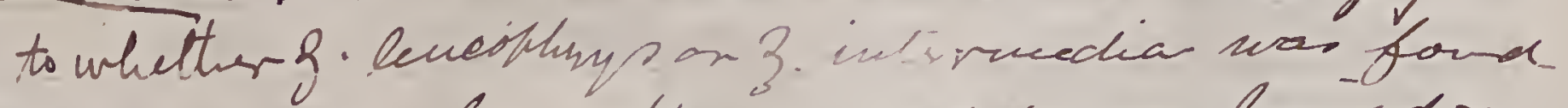
in a Ruanufy Gor artotarts randet was haired $x$ probabey bresdin:"

Empidorias fusicles. The in suany brushes near tart"1 Rande.

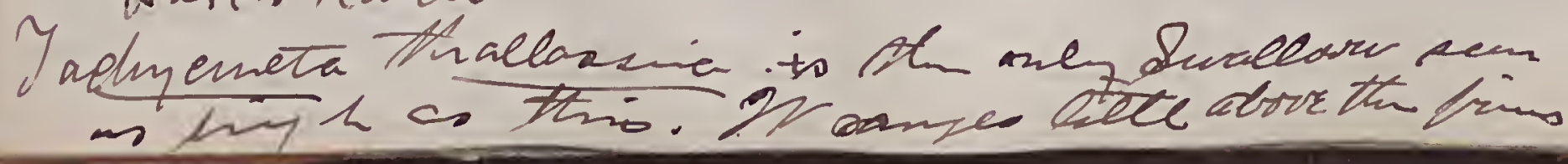

Dendurien anduboni - is the only fird of the gens

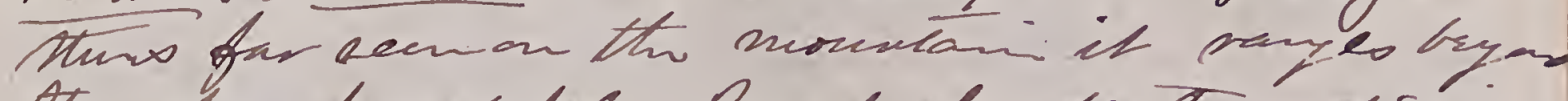

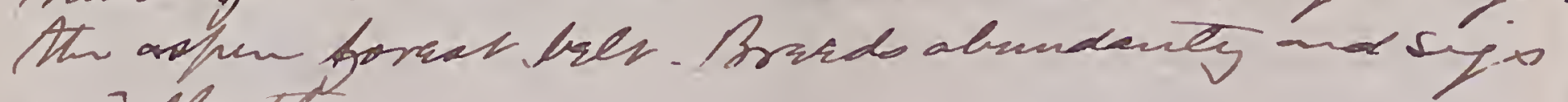
ax iellenthy

Mreiofmo melanslenens.- A aijle me moted levelof arr camp os upher fincich of funes

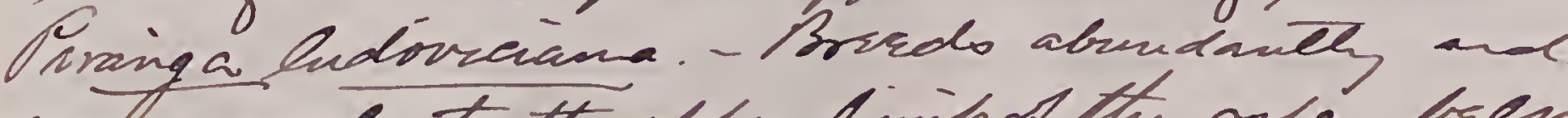

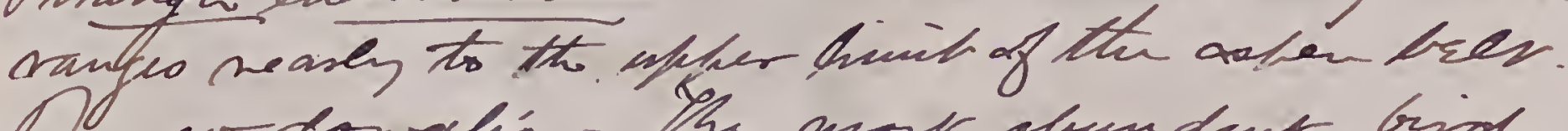

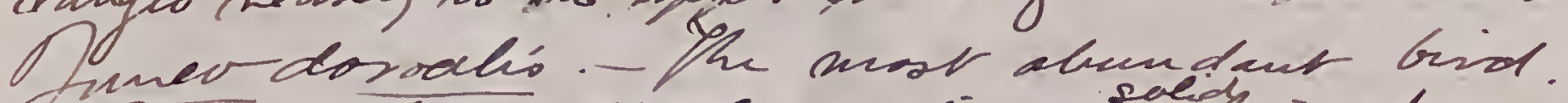

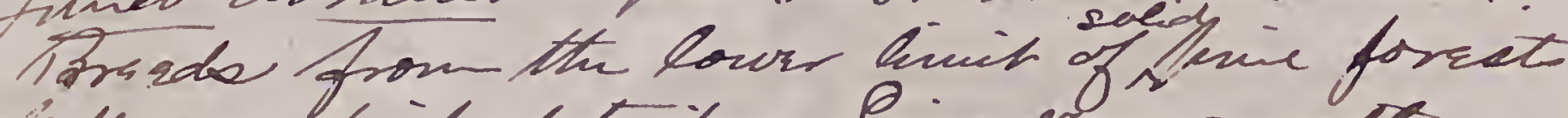

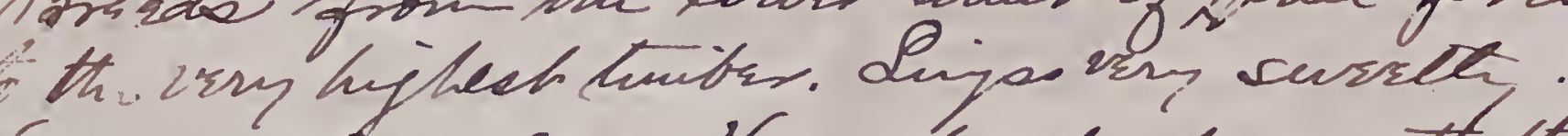

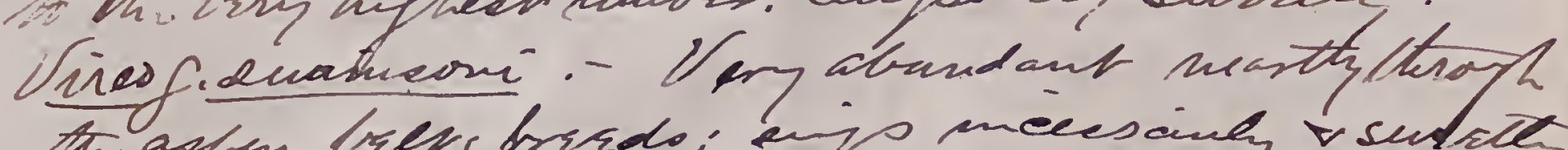
the adem brens brads; enjs meescinly vsulctely Vines plumbress has not bin detetid quite as hilt as

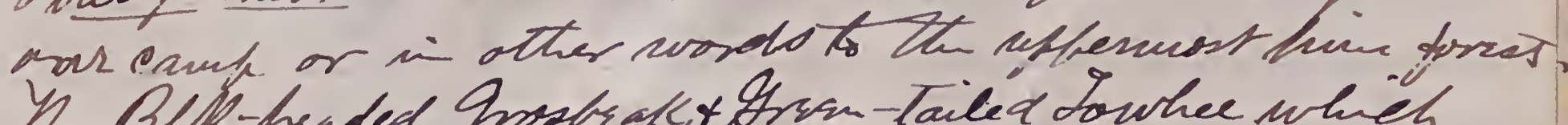

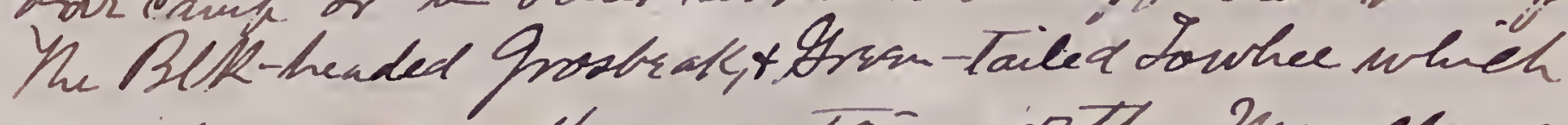
wire dbundant on the surutains ofth nojollows hays aor.bin detected here yet.

Hurnella neleeta. - Bredts a litth hijher than Thaptaff above (Imile) the 3-nich sferil).

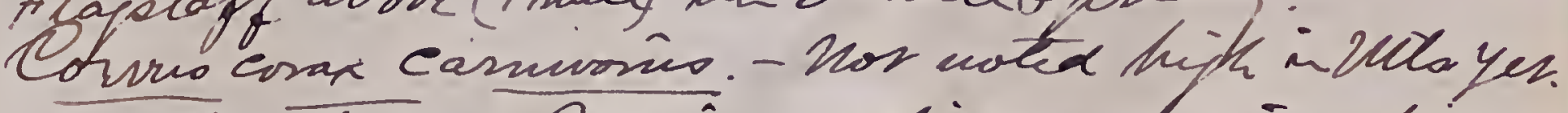

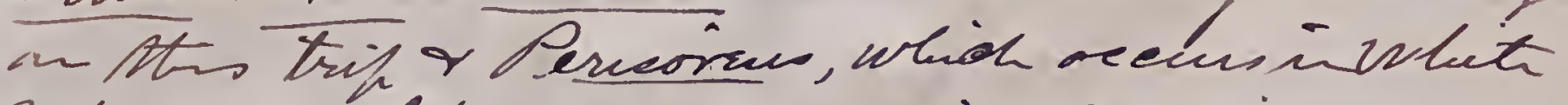
Dhto, Asij. I havs nevs rewic Argaina.

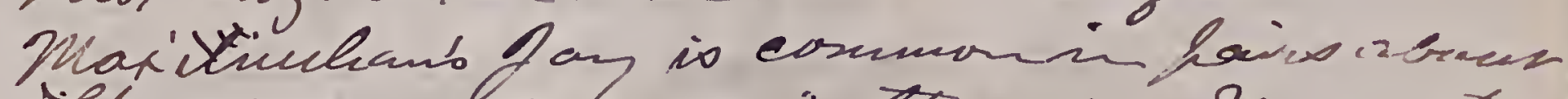

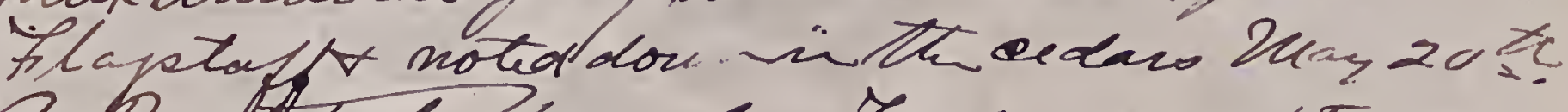

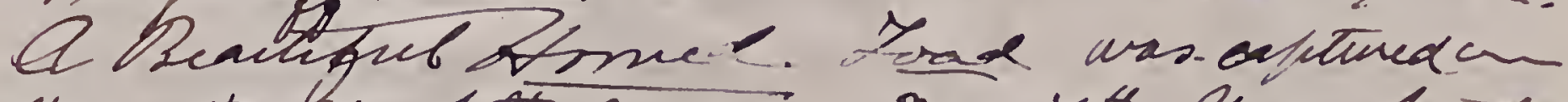

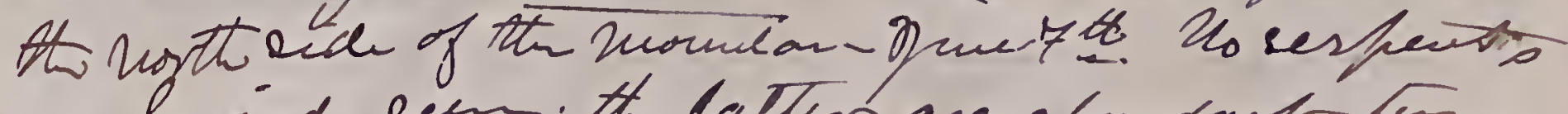
risizards seen, the latter are abundant, ter niles from here towards Hlapetoff. Ho Tortorien, ternes

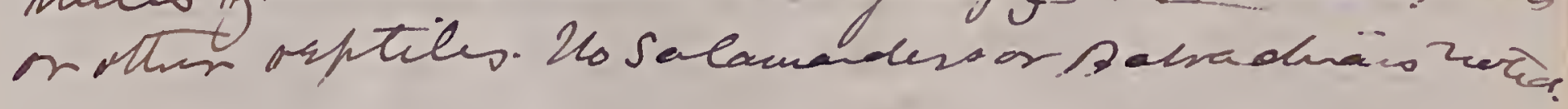


136

Contopros foraulio, - It ehanaeteriste ery is "Whif"-me-to" givm witt sach vigor and olearness of enunciatooi as to be almoat startenin.

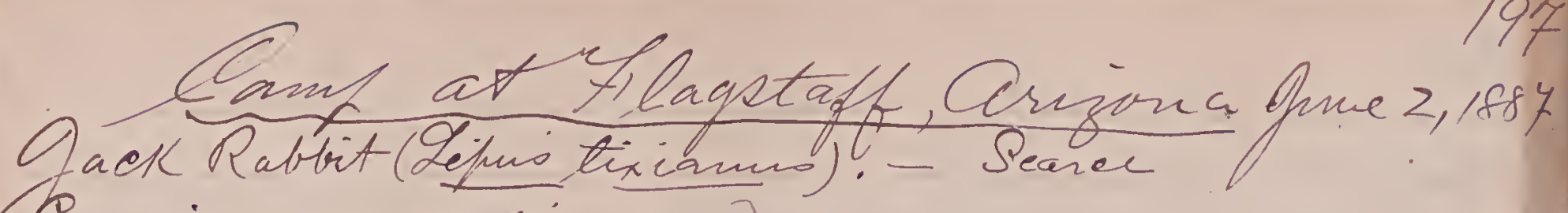

$$
\begin{aligned}
& \text { Anletoeafora americana }\} \text { Common. }
\end{aligned}
$$

Neotoma fl. muxcicann.-Abundant.

Thomian latinali. - Connow.

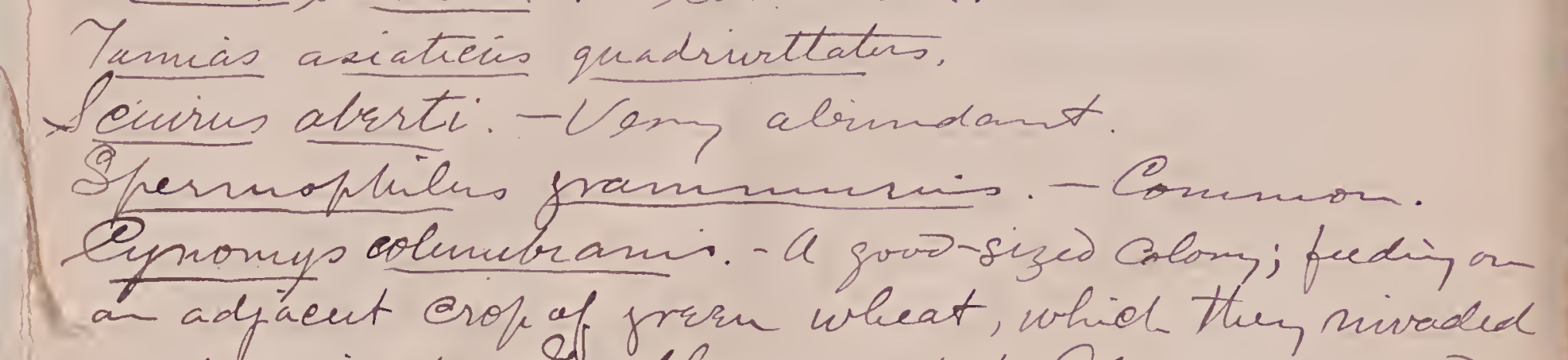
and ruined. Sntle; vin fat. Ate on; irsug ford!

- Rare Srom Rats (frobably house rats). Deveral

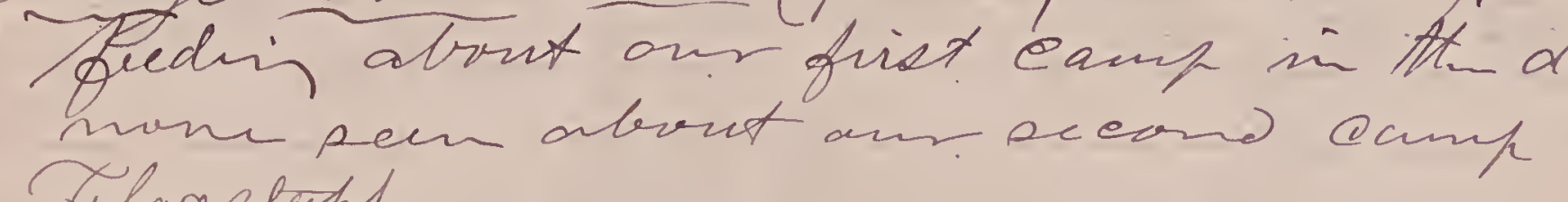
Filagslopt.

Bides sem at Hlaystaff. -

Ohippies, Red buckld gineoz, Violet-green Surallows, Purkle Martiv, Westem Nighthauk, St. Amed Cur, Max.

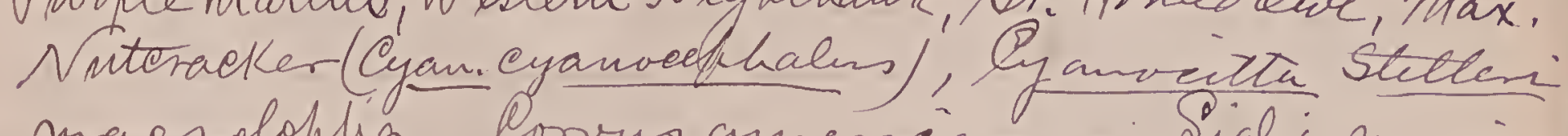
Siaretrea, Merula ruigratoria propuigua (Hians next on droopin brand of finc, 12 fect obors the groum 4 young. Nest like Castern Robin. House Vireme.-niliabiti almost Tree or rodk file in the iremith. Solaptes cafor

Dendroiea graciace

Dendroiea anduboni.

Buteo borzalis calums.

Faleo oparvarius.

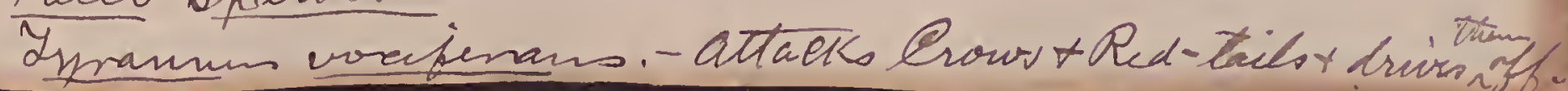



1 Sorhodytes cuenelatus

2 Sulhimila galleata

3 Ardia herodias

14

5. Nyehiorax myetiórax näenuis

I' Agralitis noeiferns.

I Aclitio maenlaria

8 Tuleca amencina

1 Qathartes aura.

- Buleo borralis calunus

11 Astur striatulatus

12 Deeviter eoopere

13 Faleo opamerins

14 Falcokingrime anatum

15 - taleo mexnearirs

16 Mrubitiriga anthacesia

17 Bub virg. subarcheus

18 Denaidura maeroura

19 Callefepla ganbeli

20 trochilus. alexandsi

2 Chordeiles texcusis

2.3 Phalãenofitilus muttalli

24 Hevoreap califoncanis

2.5-Mecapusaniercaris

26 Colafutes cafor.

27 Melaneste form. Baide

28 Pecius secularis

29 Jranus vertecális

30

- Payoms saya

" onegreaus

sontopus vichardsomi

34 Emprdiorax defficilis

is " hammondi

36 11 abcums

\& " "fusillus

38 7ny wardur eneravenk 


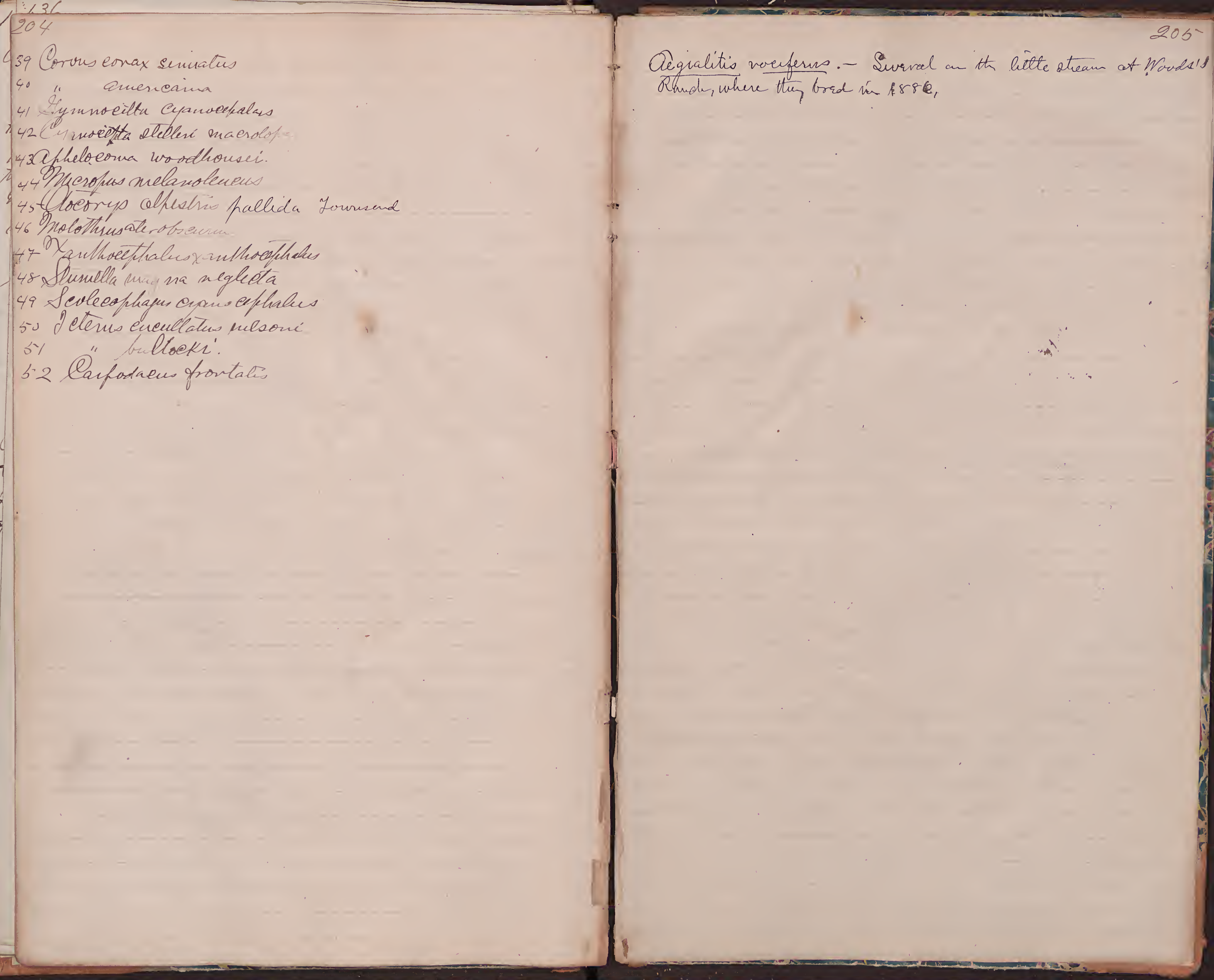


$\frac{127}{906}$

Inelanesfes formiciroms aculectus. -

The lof of the head in all yourig trivele is. red.

thene bing no blaek band in females. Yhree of Bun

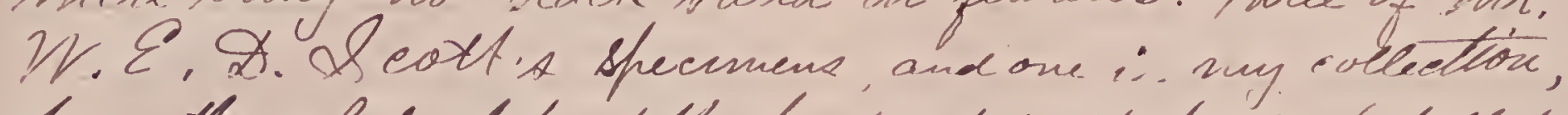
haves the whole toh of the head red, all binig fableled

females. Me quille, meck and trrast are stightly

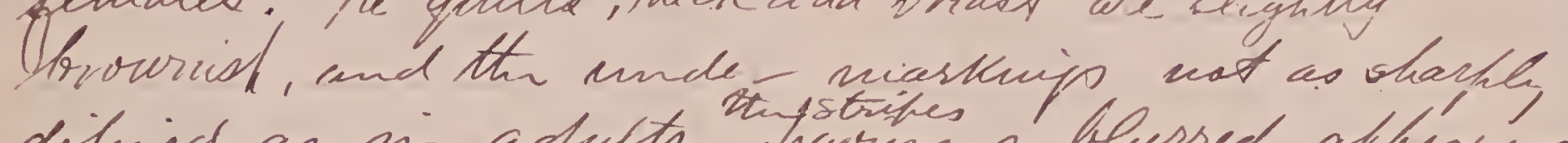

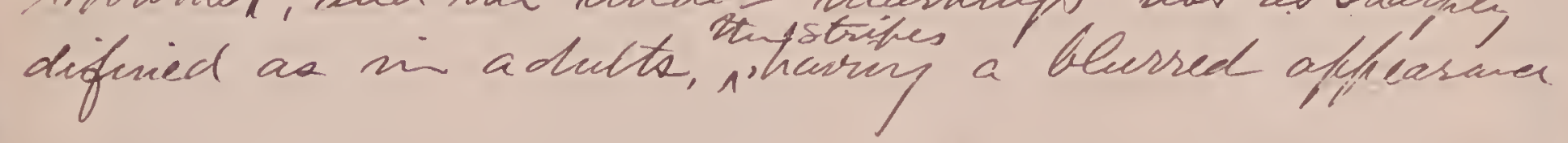

Moppe-viter page 25 or 26 lnvies.

auk frge emale tog/e 47 histos,

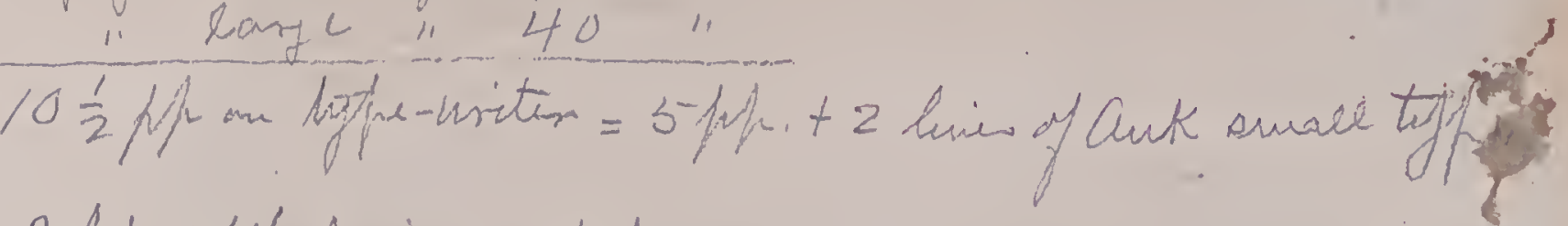

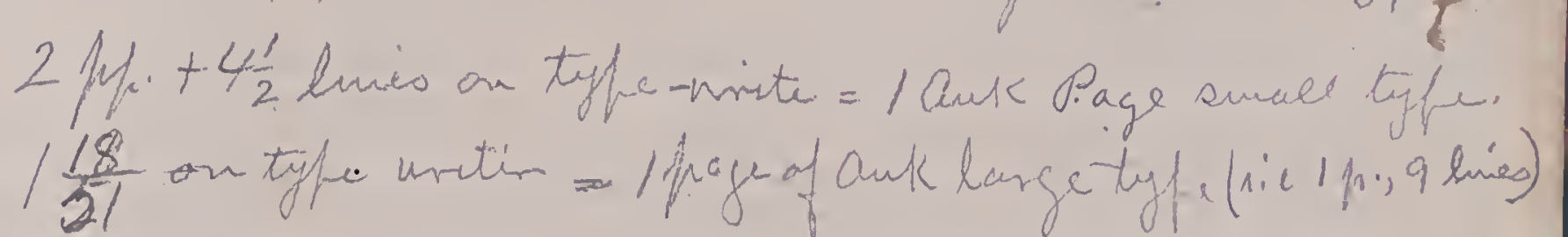

Io to from Ylagetaff to th frand Bañon.

Follow the wagon-road east along the Railivad atrout 3 miles Then tathe the left hand noad and follow the las tern bose of the mountarin. of a corrall (abour 20 miles from tilage taff). Then trum north about 2 miles to cross roads. Theince Xik.W.12 miles to thullis ranch (a mountain eheam uponitos of the nyonitam); Then fullow nain soad h.W. 28 miles to Red ftorsi jauk, oroned by Hose Casner., then 12 miles to Johnttance's, on th cañon.

from Red thore Tankes (Casner's) Dten is a trail the Qalaraer@reek. 
INDEX TO NOTES; AND IIST OF BIRDS SFEN, ON TITE TRIP FROM FORT VISRE TO THE SAN FRANCISCO MOUNTAINS, ARIZONA, FROM MAY 20 th TO

\section{JUNE 20 th, 1887.}

COLYMBUS NIGRICOLIJIS CALIFORNICUS.-- I7, 18.

IAAUS DEIAWARENSIS (var. nov.?).-- 19.

PIAIIACROCORAX ? - 5 .

URINATOR IMBER - 5 .

PUTES GUCUIJAATUS. -- 202.

ANAS BOSCIIAS.--

ANAS STREPEPA.--

ANAS AMIRICANA.-- 18.

ANAS DISCORS.--

ANAS CYANOPTERA.-- 21.

SPATULA CLYPEATA.--

DAFI IA ACUTA.--

ERISIMATURA RUBIDA.-- I7, I7.

PLEGADIS GUARAUNA.-- 21.

BOTAURUS LENTIGINOSUS.--

ARDEA HITRODIAS.-- 202

ARDFA VIRESCENS.-- 7, 202.

NYCTICORAX NYCTICORAX NAEVIUS.-- I8, 202.

GRUS MEXXICANA.--

PORZANA CAROIINA.-- IY, 18.

GALIINULA GAJIIATA.-- 202

FULICA AILERICANA.-- $1,18,202$.

ACTITIS WACUIAARIA.-- 22, 132, 202

AFGIAIITIS VOCIFLRA.-- 202, 205.

CALIIPEPLA GAMBELI.-- 202.

CYRTONYX MONTEZURAE.-- 132.

DENDRAGAPUS OBSCURUS .- - I'32.

HELEAGRIS GAJILOPAVO MEXICANA.-- 132.

COIJUMBA FASCIATA.-- 21.

ZENAIDURA IMACROURA.-- 132, 202.

CATIARTES AURA.-- 132, 202.

ACCIPITER VEIOX.--

ACCIPITER COOPTER.-- 132, 202.

ACCIPITER ATRICAPILIUS STRIATUJUS.-- 131, 202.

BUTEO BOREALIS CAIJURUS.-- 24, $197 ; 202$.

BUTEO SWAINSONI.--

URUBITINGA ANTIRACINA.-- 5, 7, 8, 202

AQUIIJA CHRYSAETOS.--

FALCO MEXICANUS.-- 131, 202.

FALCO PEREGRINUS ANATUM.-- 202.

FALCO SPARVERIUS.-- 197,202

PANDION IIAJIAAETUS CAROLINENSIS.--

NYCTALA ACADICA.-- 24.

MEGASCOPS ASIO TRICHOPSIS.--

BUBO VIRGINIANUS SUBARCTICUS.-- 7,- 133, 197, 202.

GLAUCIDIUMA GNOMA ( CALITORNICIM ?).--

GEOCOCCYX CAIIIFORNIANUS.-- 202.

COCCYZUS AMERICANUS ( OCCIDENTAJIS \&).-- 202.

DRYOBATES VIJLOSUS FYIJOSCOPUS. - $23,23,24,24,25,133$.

DRYOBATES PUBESCIENS OREOECUS. -- $23,133$.

DRYOBATES SCALARIS BAIRDI.-- 202.

PICOIDES AMERICANUS DORSAJIS.-- $8,23,25$

SPHYRAPICUS I'FYROIDITS. -- 22, 23, 133.

MEIJANTERPES FORUIICIVORUS BAIRDI.-- 8, $129,133,202.206$

COLAPTES CAFER.-- 133, 197, 202.

PHALAENOPTILUS NUTTALLI. - 202.
CHORDEIIJES VIRGINIANUS IENRYI.-- 25, $233,197$.

CHORDEILES TLXINSIS.-- 202.

MICROPUS MIILANOLEUCUS.-- I35, 204.

TROCHILISS ALEXANDRI.-- 202.

TROCHILUS PLATYCERCUS.-- 18, 24, 24, 131, 133

TYRANNUS VERTICALIS.-- 202. 197

TYRANNUS VOCI PTERANS:-- 18, 25, 133, 197, 202.

MYI ARCIUUS CINTRASCEMS.-- 202

SAYORNIS GAYA.- 20 O

SAYORNIS NIGRICANS.-- 202.

CONTOPUS BORFALIS.-- 13,21, 22, 23, 24, 24, 25, 133, 193. 136

COITOPUS RTCHARDSONII.-- 22, $133,188,202$.

EMPIDONAX DIFTICILIS.-- 22, 131, 133,202

?? IMPIDONAX CINISRITUS.-- 202.

EMPIDONAX PUSIIJUUS.-- 134.

EMPIDONAX HAMMONDI.-- 202 .

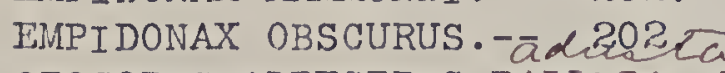

OTOCORIS ALPFISTRIS, TOWAS. -- 22, 134, 198, 204.

CYANOCITTA STTIJIJFRI MACROLOPHA.-- 18, :2, 25, .129, 134, 197, 204.

APFELOCOMA WOODHOUSFI.-- 204.

PERISOREISS CANADENSIS CAPITAIJIS.-- 135.

CORVUS CORAX SINUATUS.-- 135, 204.

CORVUS AIIERI CAIIUS. -- 21, 22, 134, 197, 204

PICICORVIS COLIMBIANIS. -- 23, 23, $131,134$.

CYANOCFPHALS CYANOCEPHALUS.-- 21, 135, 197, 204.

MOLOTIIRUS ATER OBSCURIS.-- 204.

XANTHOCEPHAIUS XANTIOCEPHALUS.) -- 121, 204.

AGELAIUS PHOENICEUS SONORIINSIS.-.

STURNELIAA MAGNA NEGIJECTA.-- I35, 198, 204.

ICTIRISS PARISORUM.--

ICTERISS CUCUIJIATUS NJILSONI.-- 204.

I CTERUS BUJJIOCKI.-- 204.

SCOJECOPHAGUS BYANOCEPIALUS.-- 121, 134, 198, 204.

CARPODACUS MEXI CANUS TRONTAIJIS. 204.

LOXIA CURVIROSTRA STRI CIIJAINDI.-- 25.

SPINISS FSAJTTRIA.-- 25.

POOCAETFS GRAMINEUS CONFINIS.-- 22, 134.

CHONDESTISS GRAMHACUS STRI GATUS.--

ZONOTRICHIA IJEUCOPIIRYS.-- 134.

ZONOTRI CHIA JJUCOPIRYS INTERMEDIA.-- 134.

SPIZILLA SOCIAIIS ARIZONAF.-- 24, 25, 25, 134, 197.

JUNCO CINEREUS DORSAIJIS.-- $1,1,22,22,23,23,24,131,135,197$

AMPIIISPIZA BIJINEATA.-

PEUCAFA RUFICEPS BOUCARII.-

MELOSPIZA FASCIATA FAIILAX.--

PIPILO MACULATUS MEGALONYX.--

PIPIIO CHLORURUS.-- 135.

PIPIJO FUSCUS MESOLEUCUS.--

Pipilo aberti.

CARDINALIS CARDINAIIS SUPERBUS.-- 7 .

ITABIA MIFLANOCEPHALA.-- 18, 135.

PIRANGA LUDOVICIANA.-- 21, 22, 135, 198.

PIRANGA HEPATICA.-- 22, 24, 25, 198.

PROGNE SUBIS.-- 18, 197.

PETROCHELIDON LUNIERONS.--

CIIELIDON ERYTIIROGASTER.--

TACHYCINEIA THAIASSINA.-- 21, 134, 197.

STELGI DOPTHEYX S.ERRI PFNNIS. -

PHAI NOPEPIA NITENS.--

LANIUS LUDOVICIANUS IXXCUBITORIDES.-

VIREO GILVUS SWATNSONI.--7, 18, 21, 22, 135. 


\section{(licage 9.)}

VIREO SOLITARIUS PLUMBEUS.- 21, 22, 135, 198.

VIREO BELII PUSILIUS.-

VIRIO VICINIOR. -

HELMINTHOPIIIIAA LUICI AิE.-

DENDROICA aestiva sonorana.-

DENDROICA AUDUBONI. 23, 131, 135, 197.

DENDROICA GRACI AF.- 8, 18, 21, 197.

DENDROI CA NIGRTSCENS. -

GEOTHIJYPIS MACGIJIIIVRAYI . -

GEOTILYPIS TRICHAS OCCIDENTAIIS.-

ICTERIA VIRINSS IONGICAUDA.- -

SYIVANIA PUSIJIA PILFOIATA.-

OROSGOPTES HONTAINUS. -

MIMUSS POIYGLOTTOS.-

HARPORHYNCHUS CRISSAIIS.--

SALPINCTES OBSOLETUS. - 18, 197.

CATITARPES MIEXICANUS CONSPERSTS.-

TROGIODYTES AEDON AZTECUS. - 22, 233, 197.

CERTHIA FAIILIARIS ( MONTANA ?).- 24, 134, 22.

SITTA CAROIJINENSIS ACULEATA.- 134.

SITTA CANADENSIS.- 18, 134.

SITTA PYGMAEA... - 21, 25, 134.

PARUS INORNATUS GRISEUS. -

PARISS WOILUEBERI.-

PARUS GAMBEIJI.- 24, 131, 134.

PSALTRI PARUS PIUMMBEUS.-

AURIPARUS FIAVICEPS.-

REGUILUS CALENDUT,A. - 18, 22, 134.

POLIOPTILA CAERUIJAA

MYADESTES TOWNSIENDII - -

TURDUS USTUIATUS"MEARNSI".- 18.

TURDUS AONAIASCIFKAE AUDUBONI.- 18, 22, 24, 133.

MERIJAA MIGRATORIA PROPINQUA.-- 133, 197.

SIAIIA MEXICANA. - 24, 133, 197.

SIALIA ARCTICA.- 8, 24, 134, 197.

HORNED TOADS.-- 135.

REPTIIISS AND BATRACIIIANS.-- 135.

N $O$ T. E. - The above is a complete list of the Birds seen on the san Francisco trip, from the 
Provides americans dorsalis. Affine thre-tord Woo th Reeker. - Breeds e commonly throughout the pin ie belt, seldom ascending far into the sprue moods of the highest peaks. 


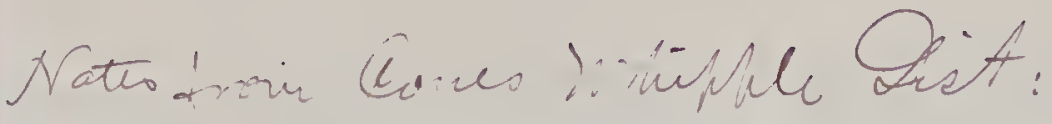

No Halev kikunbanis. Common; secident.

Ys. Leverre eys caleformanins

No- "Splypapiñ senchalis." "Permanent resdent. "Cbendant. Yer Asyndermuo torguatis "Conmon; resident."

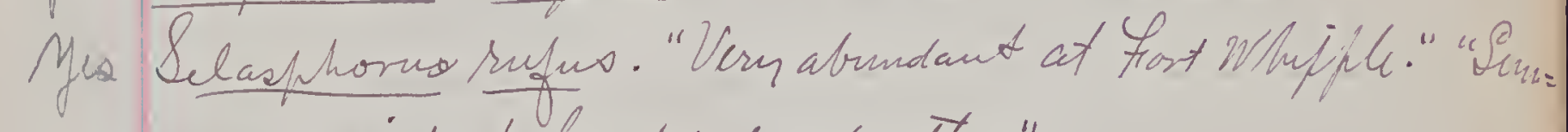
=mer resident, brercinjabundantty."

Yes Palioptila càernelea. "Semmen riecdent." Dendrorea mifreseeno. "Conmon"; "but tofew brad."

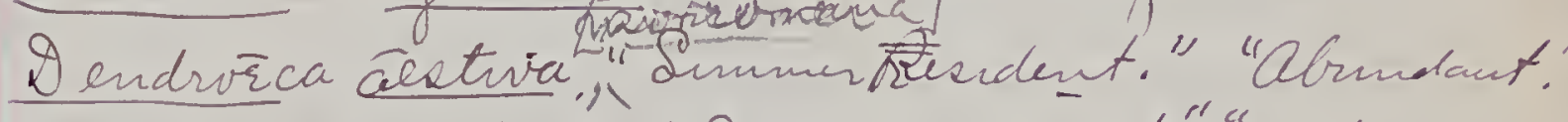

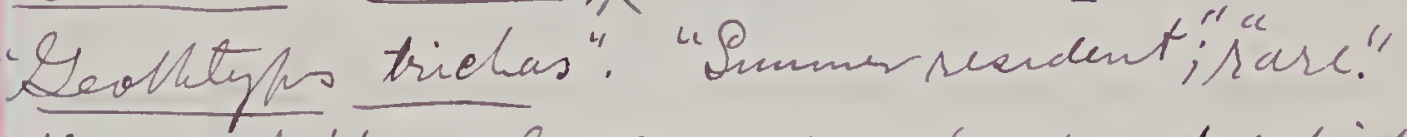

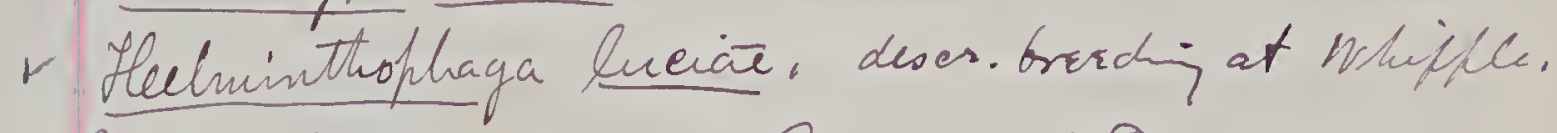

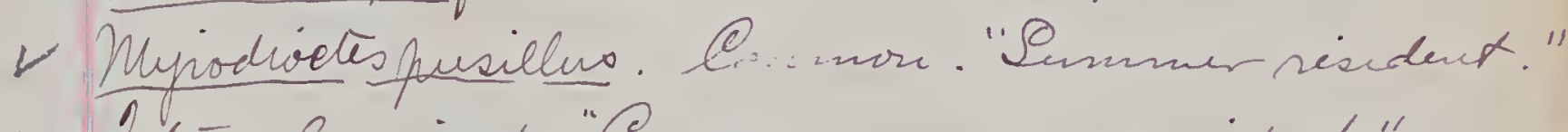

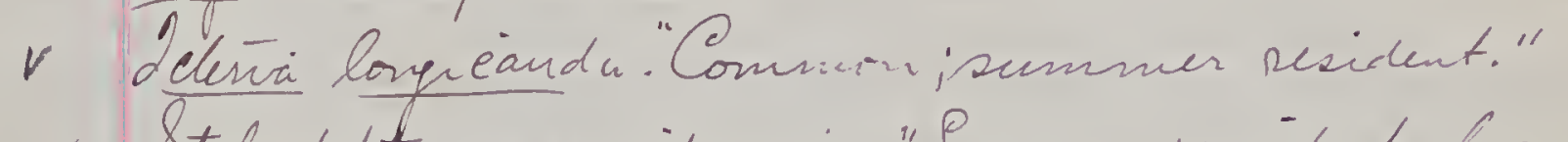

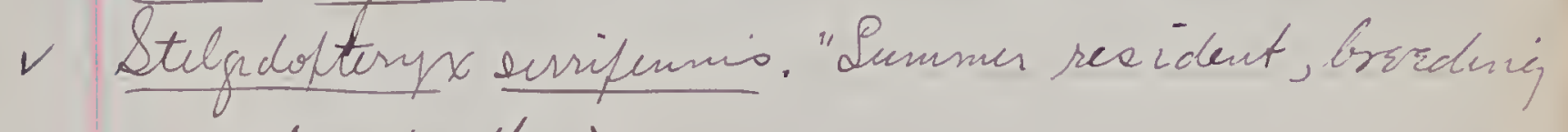
abundantty."

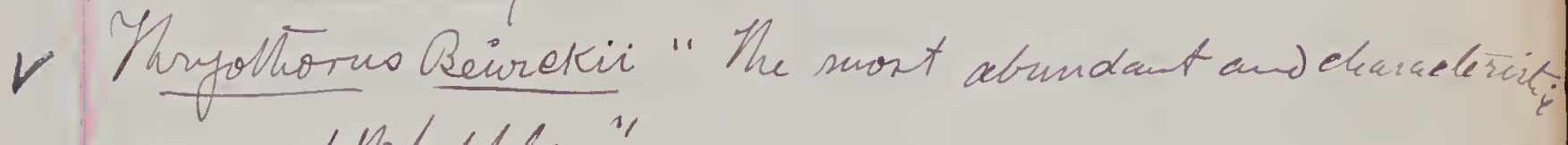
wren at Vheffle."

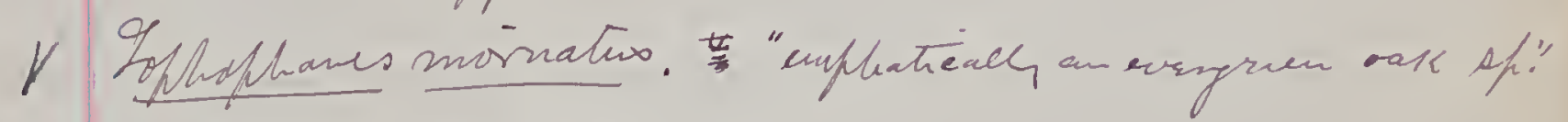
escheromin the funios ete.

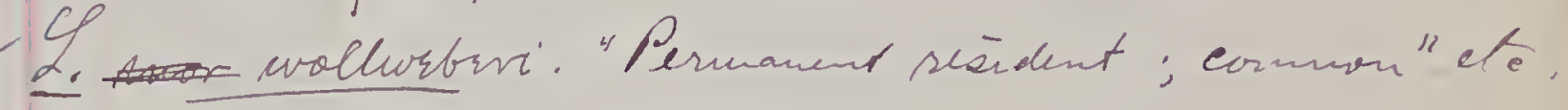

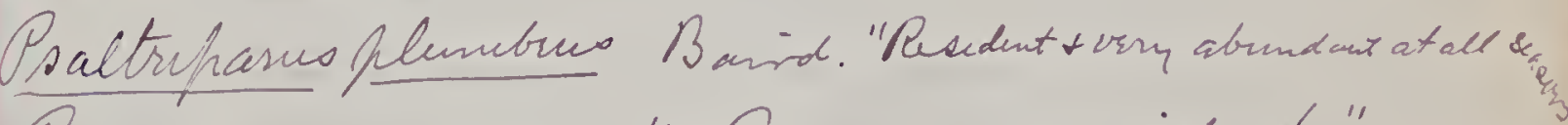

TCaspodaeno eassini" "Common; sesident."

1 Sffiella atrijularis rase sumen rasidurt ot Whifie.

$\checkmark$ Molotherus heors "Ven abundant despmer sicident."

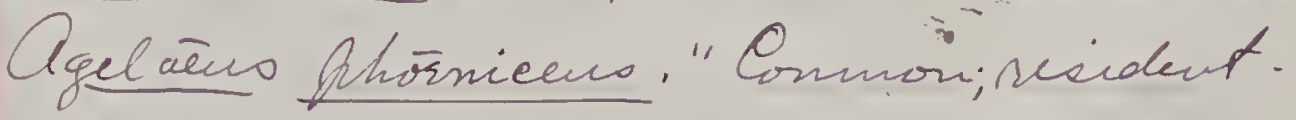




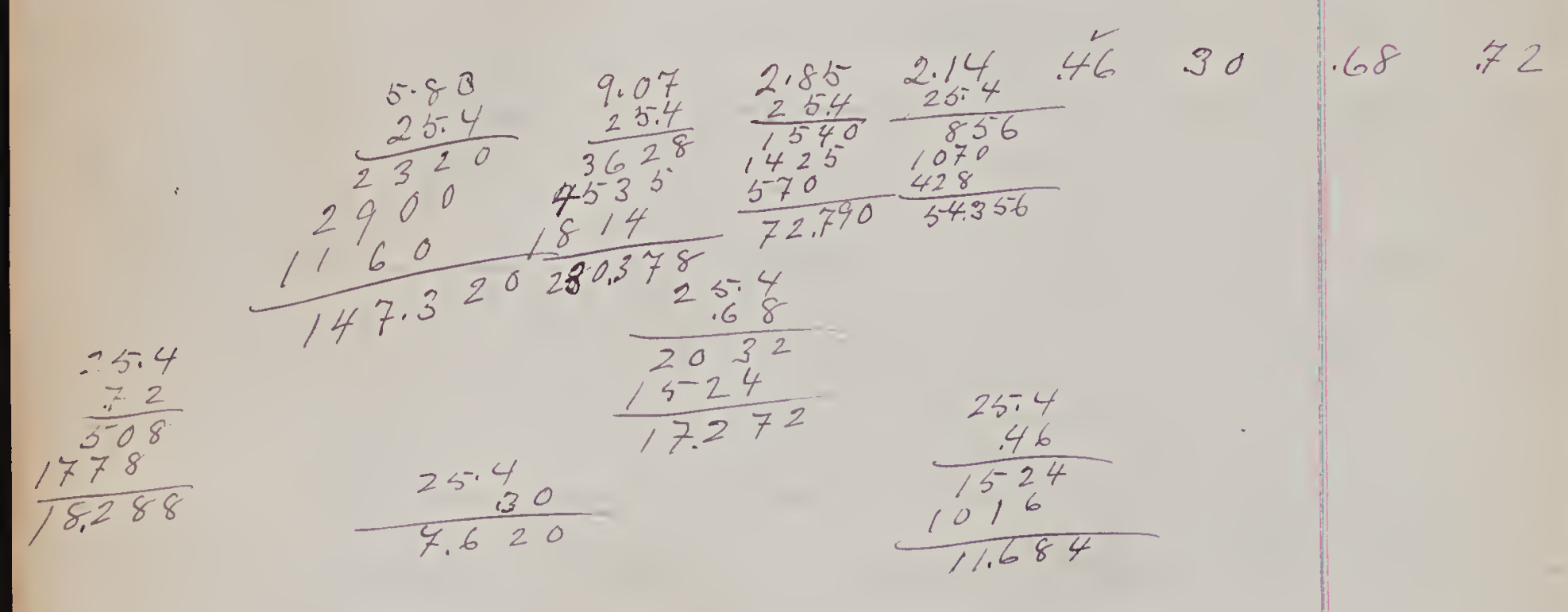




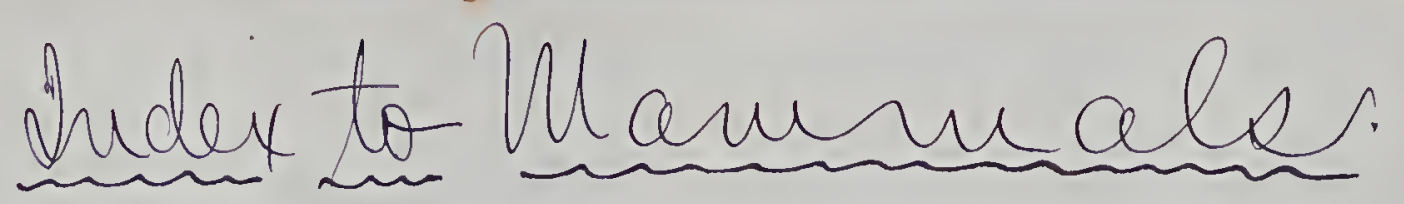

3/ crnoms columbianus (ord) Allen. Westem Barking Squirrel.14,15, 19,129,197.

32 TAMTAS IATERAils (Say) Allen. Say's Chipmunk. $14,15,16,128,131,197$.

33 tailas ASIATICUS QUADRIVATtatus (Say) Allen. Rocky hountain chip- $14,15,16,128,131,197$.

34 TAMki DOS DORSAIIS Baird. Gila Chipmunk $/ 6$

35 TAMIAS IIARRISI (Aud, and Bach.) Allen. Harris's Chipmunk.

36 SPERMOPHIIUS GRAMRURUS GRAMUIURUS (Say) Allen. Rocky Mountain, 7, 14, 128, 197.

Iine-tailed Spermophile.

37 SPERMOPHILUS TERETICAUDUS Baird. Fort Yuma Spermophile.

38 SCIURUS HUDSOHIUS FREHONTI (Aud. and Bach.) Allen. Tremont's Chick-14,15,16,129,131,

39 arec.

40 scIURUS ARIZONEASSTg gones. Arizona Squirrel.

$4)^{\circ}$ CASTOR-FIBER Linne. Beaver.

44 FIBER ZIBETIIICUS (Linne) cuvier. Nuskrat.

45 HESPEROMYS TORRIDUS Coues. Arizona Mole Mouse.

46 hesperomys temucopus sonoritensis (Le conte) cones. 14,132,

47 HESPEROMYS LEUCOPMS ERERICUS (Baird) Cones. Desert Mouse.

Arvicula str?

SIGHODON IIISPIDUS ARIZONAE Arizona Cotton Rat.

NEOTOMA CINEREA (Ord) Baird. Bushy-tailed Wood Rat.

NEOTOMA FLORIDANA IJEXICANA. Wood Rat. 128,197

THOMOMYS TALPOIDES URRBINUS (Richardson) coues. Southem Pocket, $-128,131,197$.

Gopher.

THOMONYS - sp. ?

DIPODOMYYS PHILLIPSI ORDI (Woodhouse) Coues. Ord's Pocket Rat;

"Kangaroo Rat".

LEPUS SYLVATICUS ARIZONAE AIlen. Desert Hate.

LEPUS SYLVATICUS NUTTALII (Bachman) Allcn. Sage Hare.

7 LEPUS TEXIANUS Waterhouse. Northem Jackass Hare. 8, 128, 132,19\%.

LEPUS CALIOTIS Wagler. Southom Jackass Hare.

42 Smus decumanus, Drabetic, Rat-197,

437 mus masentus 2 anestie Norse.

Moler.-127, 132, 
Telb domesticirs, 132 ,

, IFELIS CONCOLOR Linne. Panther; Mountain Lion. 1.32,

$\sum$ LYNX RUFUS MACULATUS Audubon and Bachman. Texas Wild Cat.

3 Lynx ?

$\psi$ Bassaris astuta Licht. Civet Cat.

5 CANIS LuPUS Linne. "Timber Wolf." $/ 32$,

6 CANIS IAATRANS Say. Prairie Wolf: Coyote. 127,132,

7 VULPRS VELOX Audubon and Bachman. Kit Fox; Swift Fox.

8 UROCYON CINEROtARGEnTATUS (Schreb.) Coues. Gray Fox. $127,132,19 \%$

9 GULO LUSCUS Sabine. Wolverine.

10 Putorius braziliensis Prenatus (Iicht.) Bridled Weasel. 130

// WEPHitis IEPHiticA. Baird. Common Skunk. 127 ,

12 MEPHITIS INTERRUPTA. Little Striped Skunk.

3 CONEPATUS MAPURITO White-backed Skunk.

14 Yaxidia amerieana - . - Anerican Badger

is TAXIDEA AIIERICANA BERLANIIERI _........ l.exican Badger.

16 LUTRA CANADENSIS Sab. American Otter.

If PROCYON HERINANDEZII. Califomia or Black-footed Raccoon.

18 Ursus horibilis Ord Grizzly Bear. 132

19 URSUS AMERICANUS Pallas. Black Bear; Brown Bear., -132 ,

20 DICOTYIES TORQUATUS Cuv. Texas Peccary; Mexican Hog.

2) CerVUS CANADENSIS Erxl. American EIk.

- 2 CARIACUS VIRGINIANUS GROOKI (et MEXICANUS). Arizona Deer.

23 CARIACUS MACROTIS.

wule Deer. $128,132,197$.

24 ANTilocapra niericana ord. Prong-Horm Antelope; Cabree. $14,128,132,197$.

25 OVIS MONTANA Cuvier. Hountain Sheep; Bighorn./30,/3/,

26 mole (sp. ?).

Y) Little Brown Bat.

2 F Large Brown Bat.

9 Red Bat.

Long-eared Bat.

Bate in queral. - 127,132 
2

Halev peregrinus oriatum.

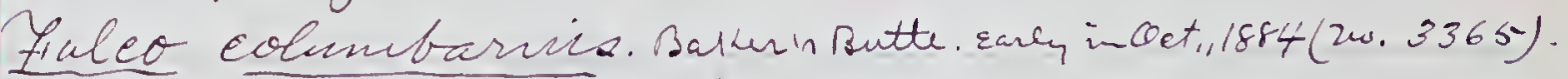

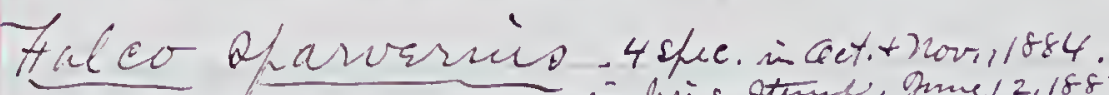

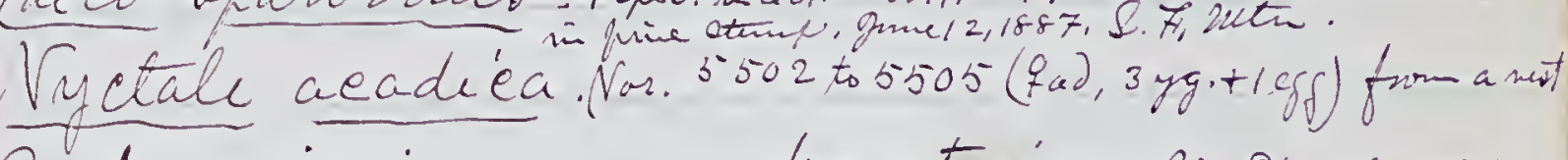
Bubo virginanus pubaretecie. Pine S/ps. Norirs84.

Speotyto?

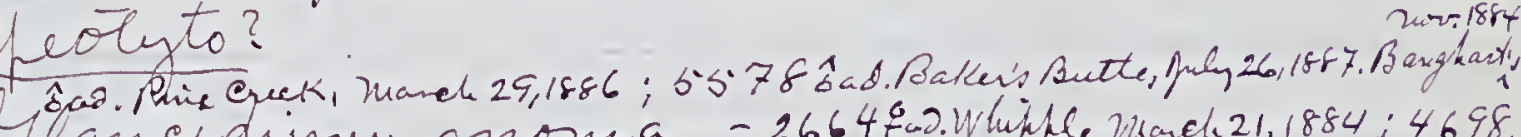

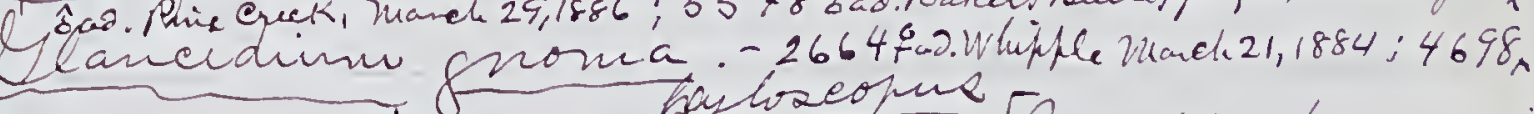
Dimjobates villosur

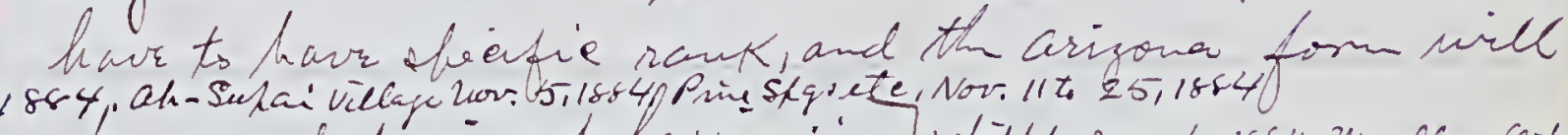

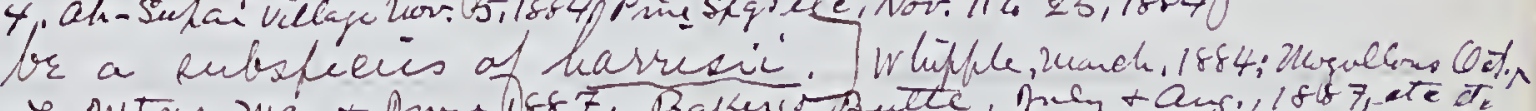

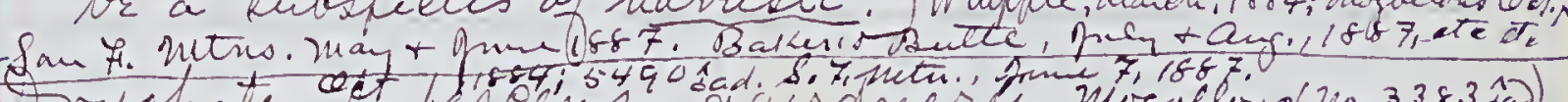

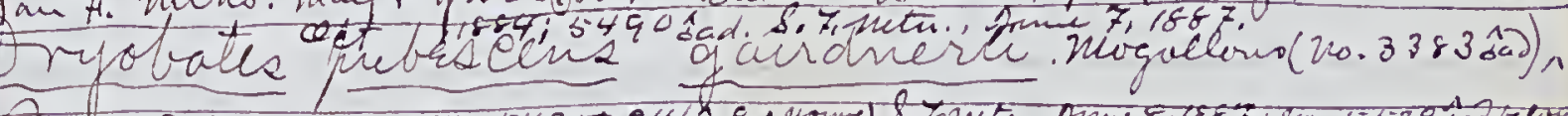

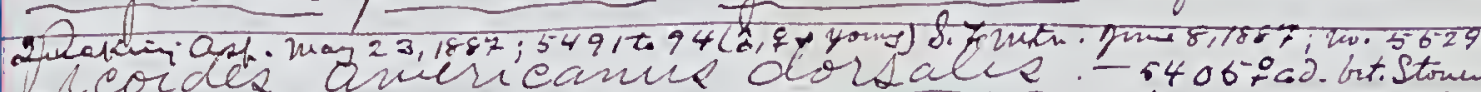

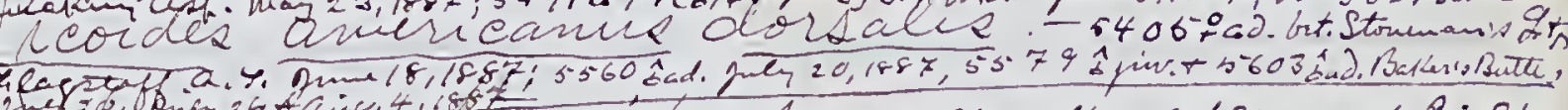

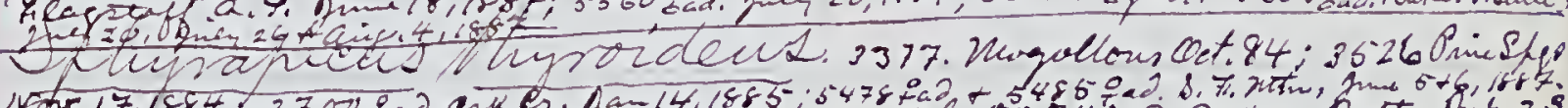

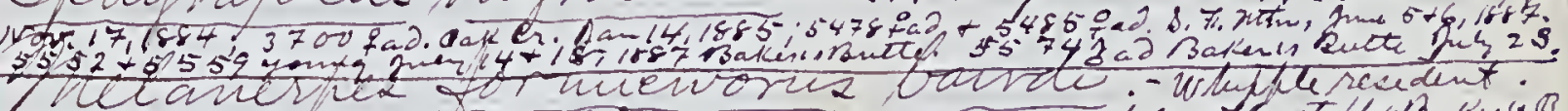

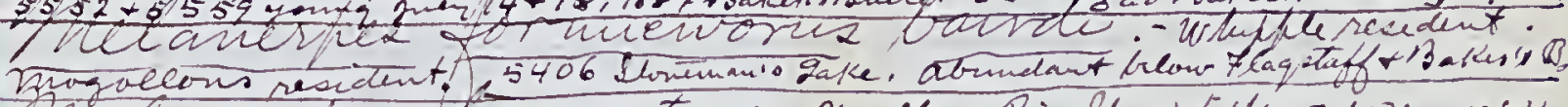

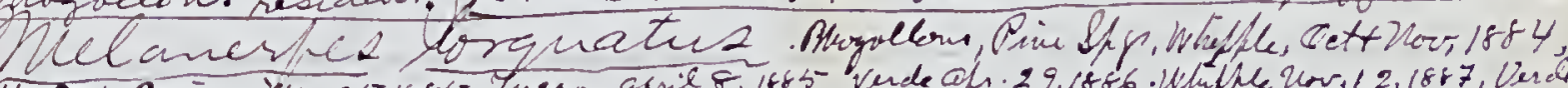

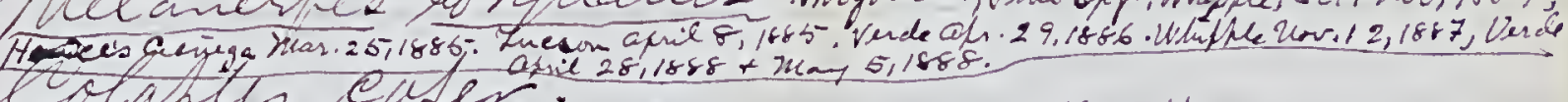

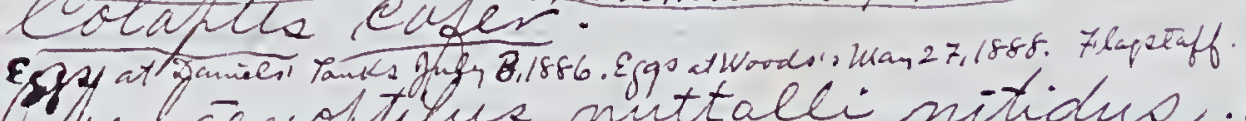
Lual aenopticus nuttalli nitidue whiffeaph.1884,

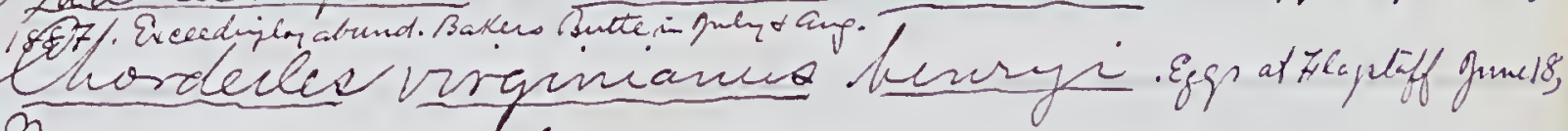

M) Nierofus melanveneus.

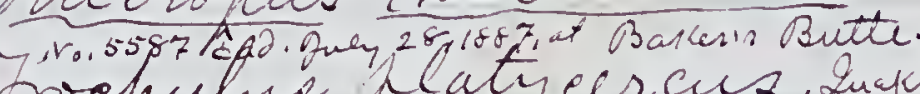

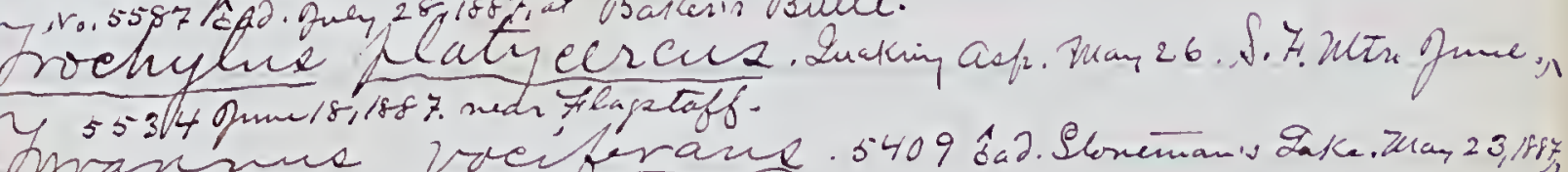

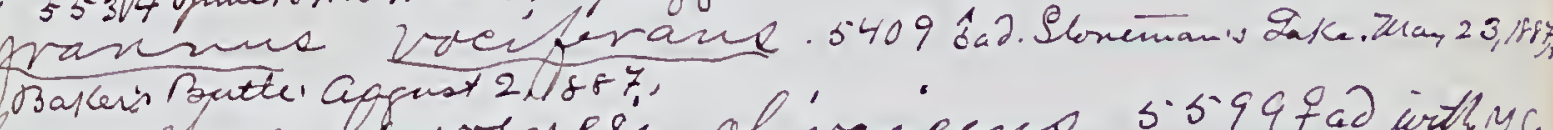

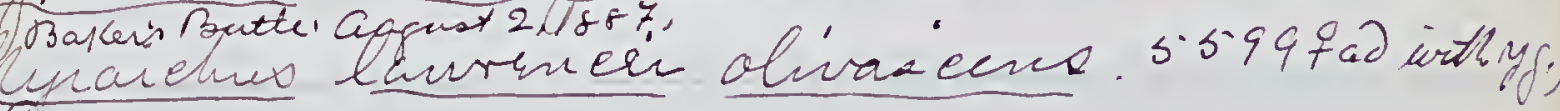
ayormis daya.

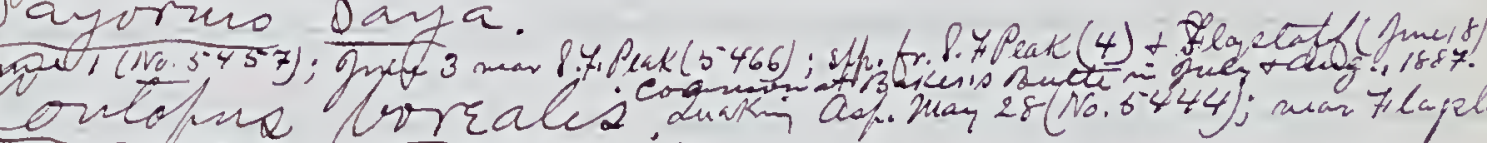

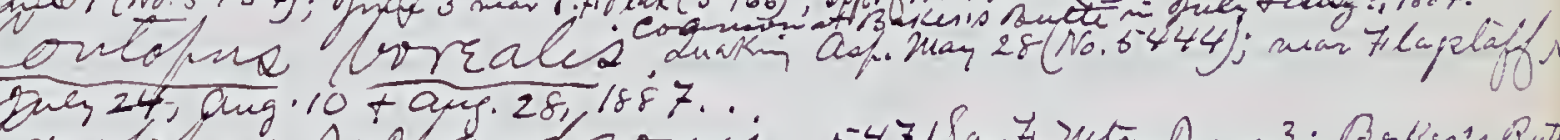

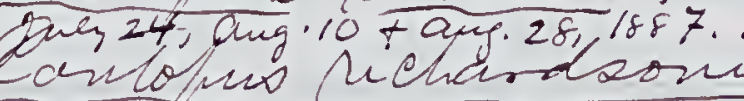
(B) Basceris vouthe Dutr 27.1887.

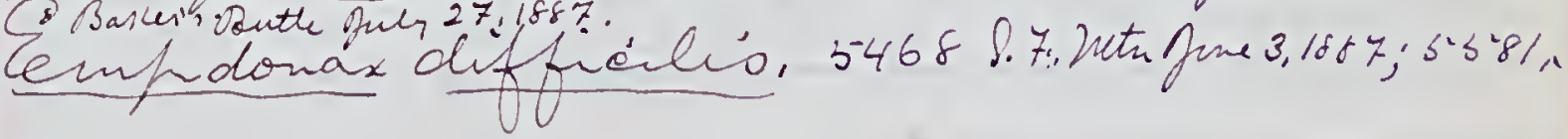

Cetoris alfoatus. $\quad 5464 \hat{\mathrm{bad}}$. near 8.7. Peak, gine 3,1FF7. Extra hon cearrf haleny. 
3

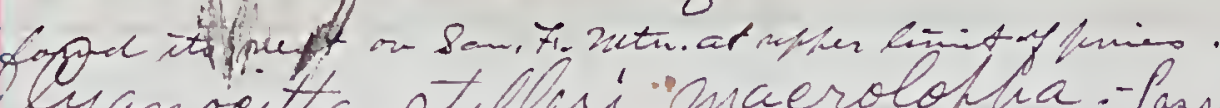

yanocetta ptelleri"maerolopha. Passes thro thinibet.9,

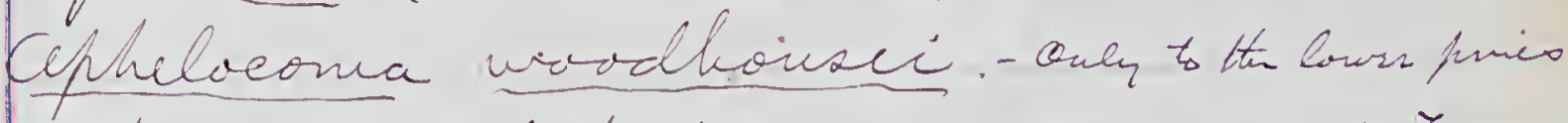

Afhelocona Riebarii arizonad. - do Tow Bami erioorens canadencis cafitalie, Whit notios.

Covus corax sinuatur. sormpuhue.

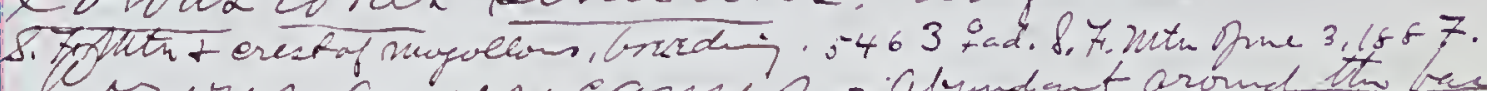

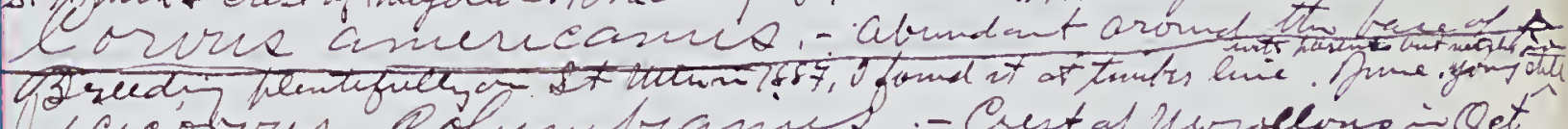

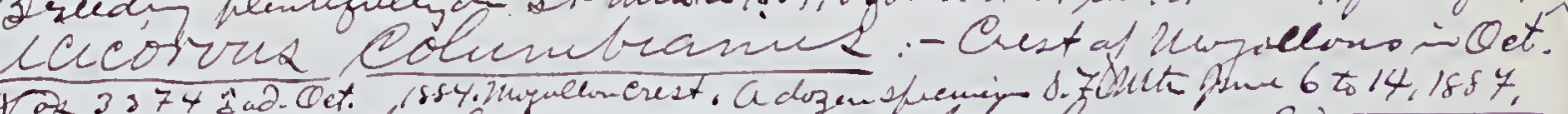

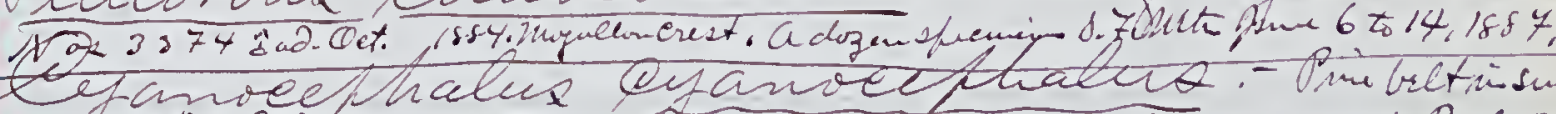

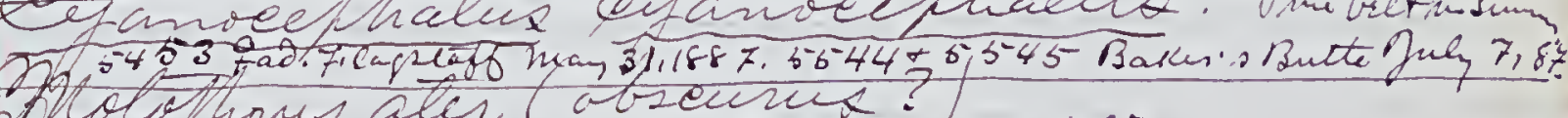

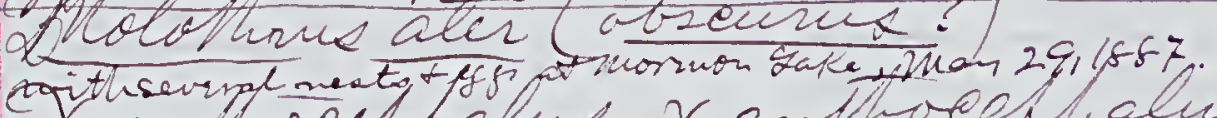

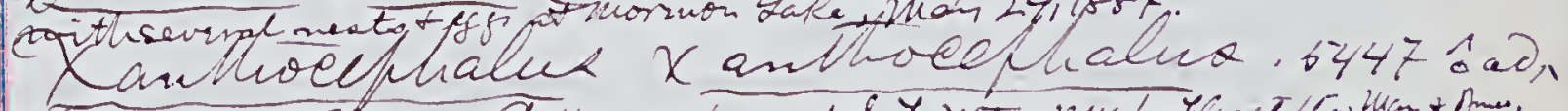

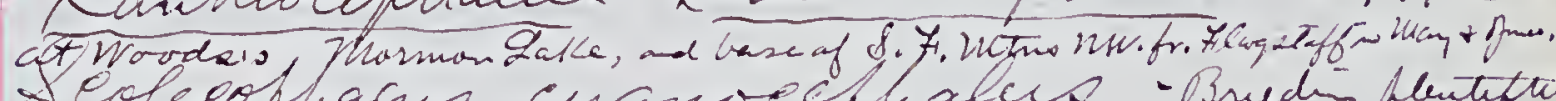

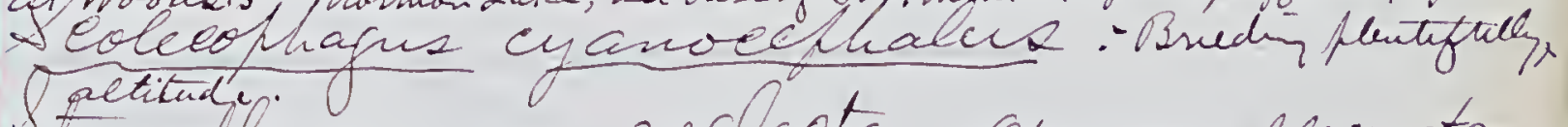

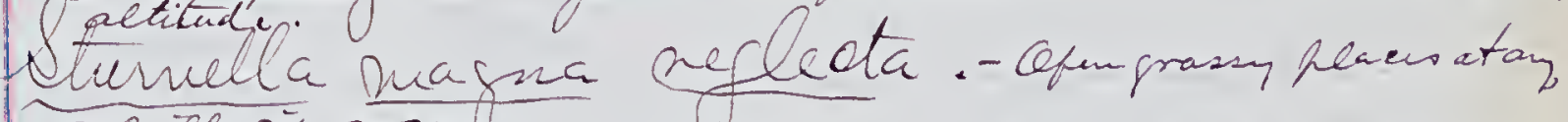

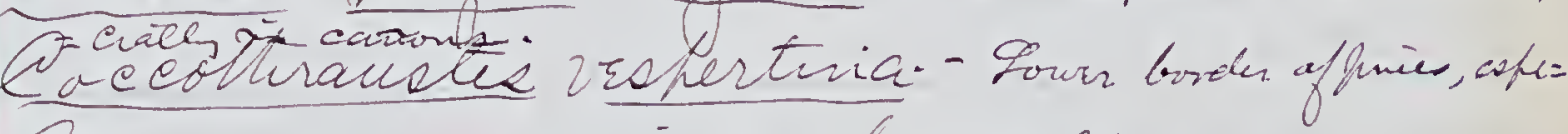
Carpodacus mexceamio fortalis.

Carpodacur casoini.

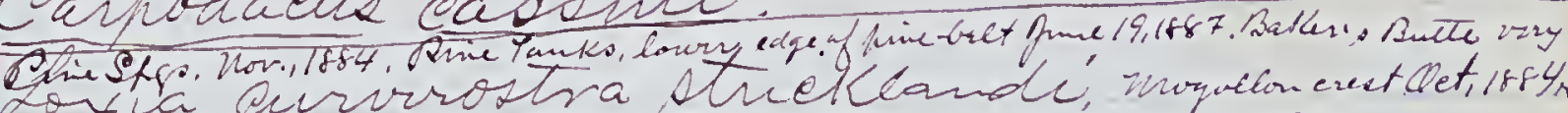

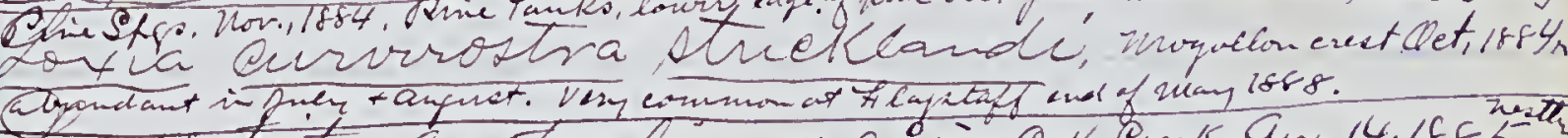

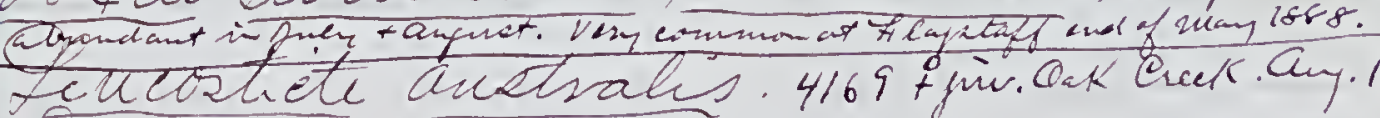

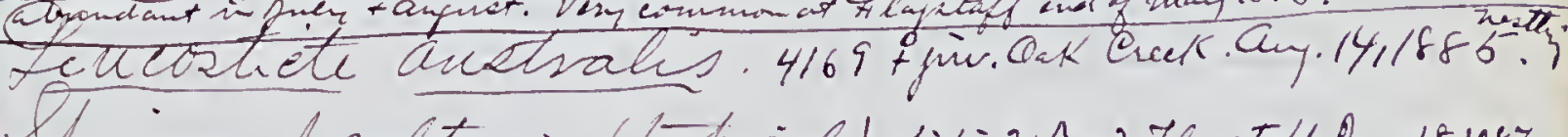

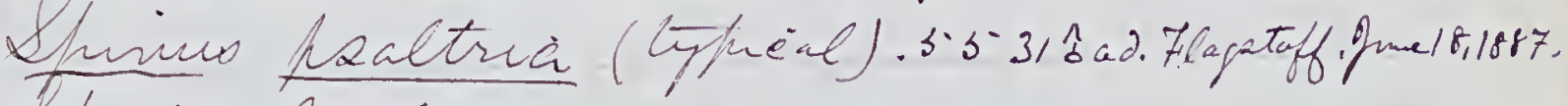

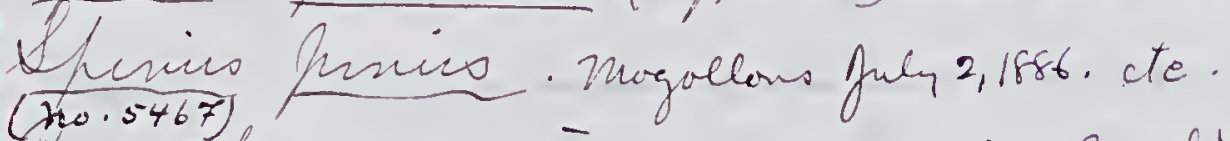

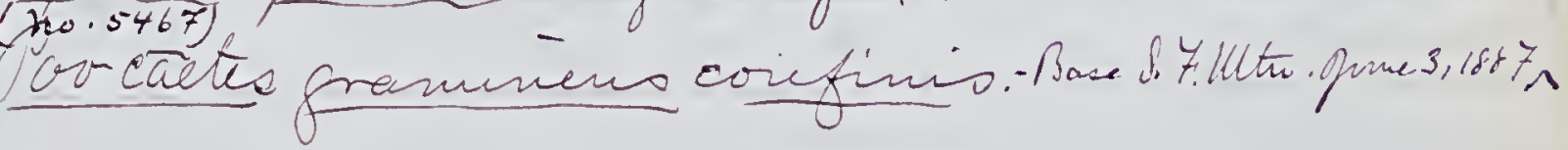

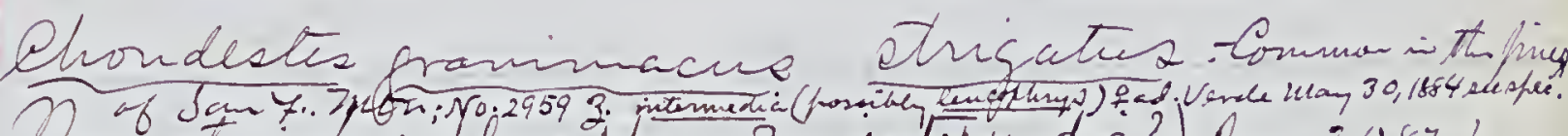

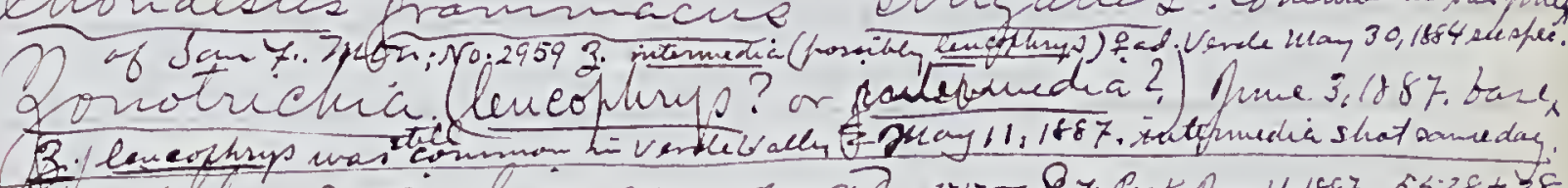

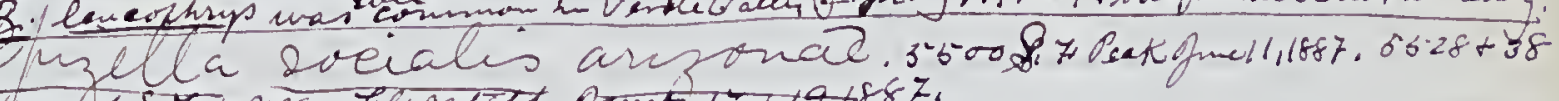

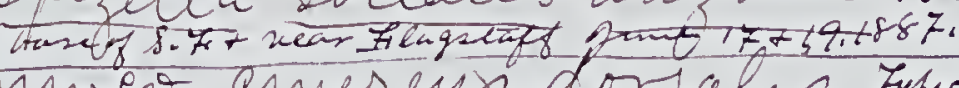

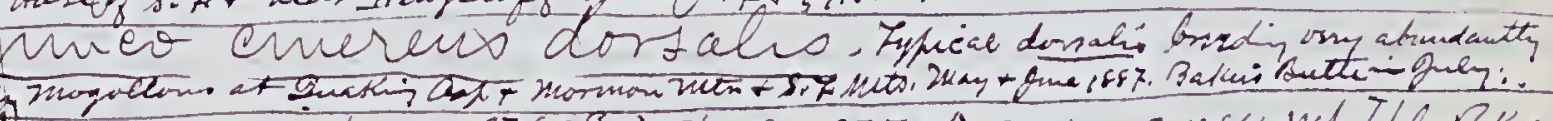

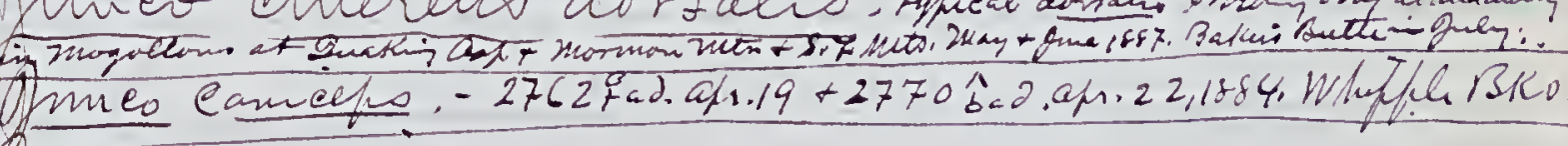

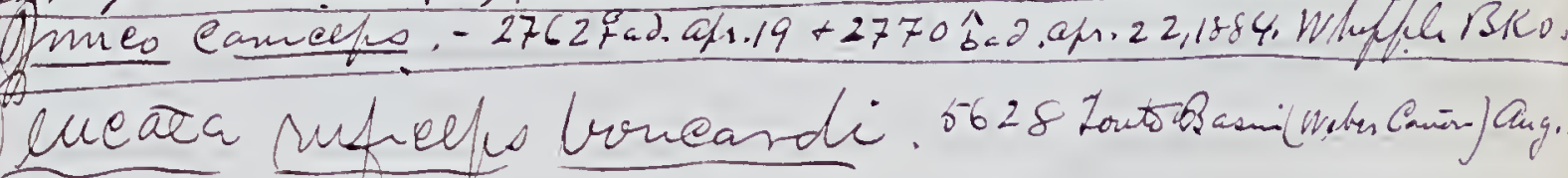


4

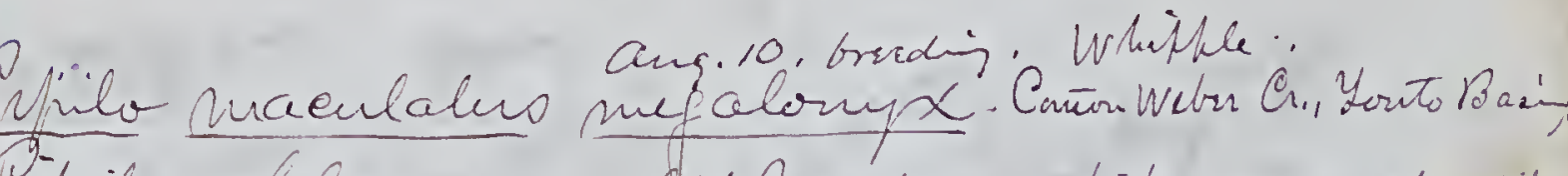

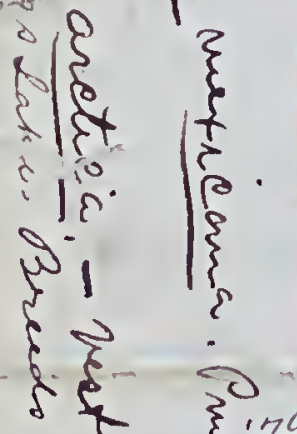

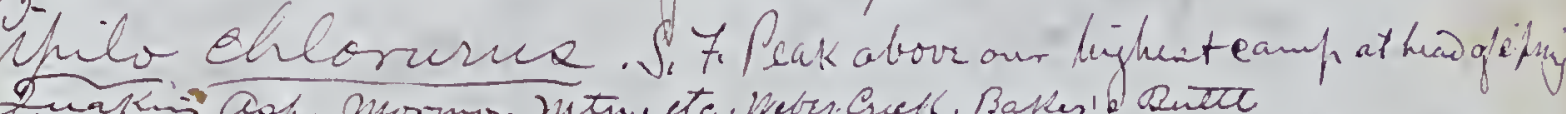

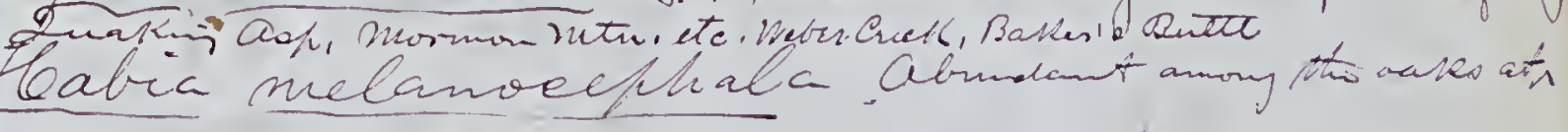

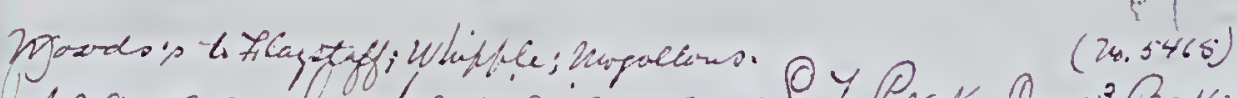

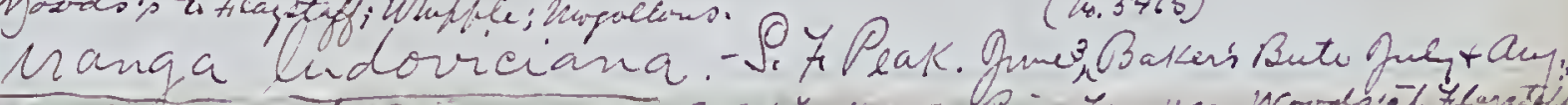

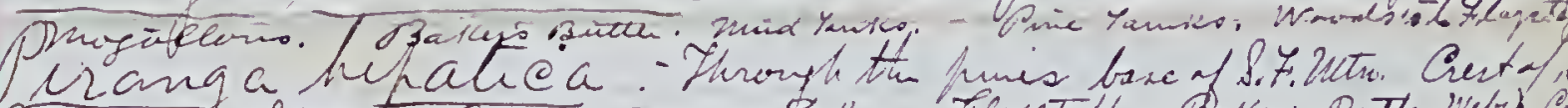

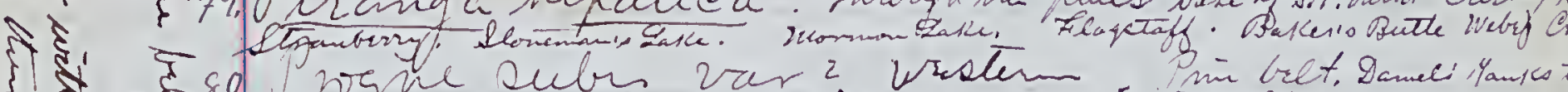

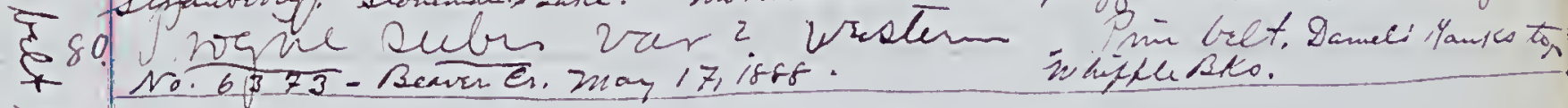
on 10.6373 - Bewren $e_{1}$ may 17 if of .

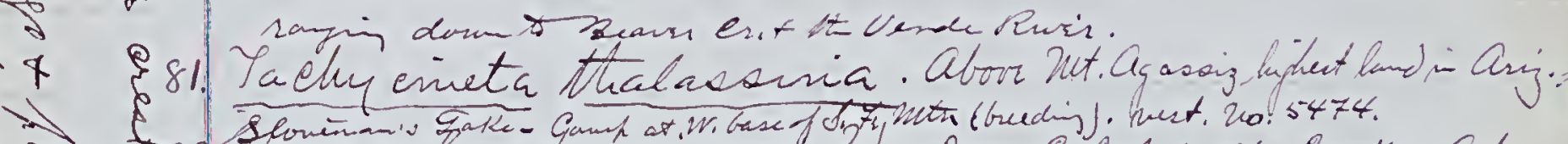

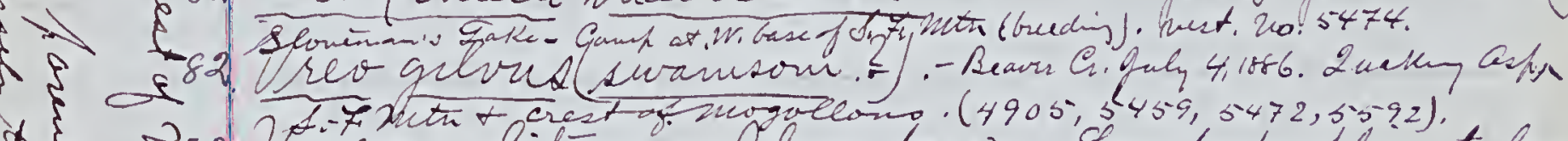

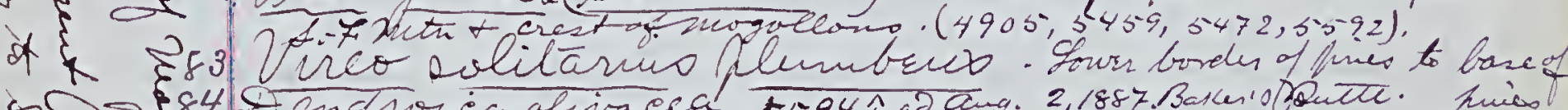

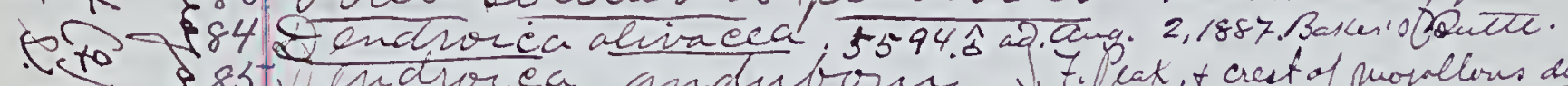

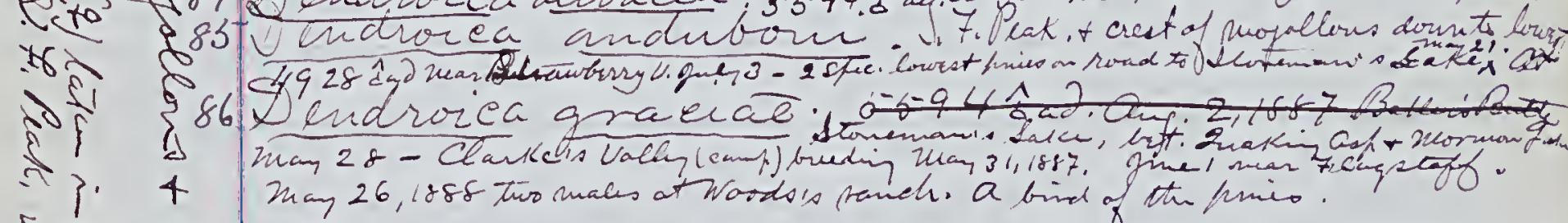

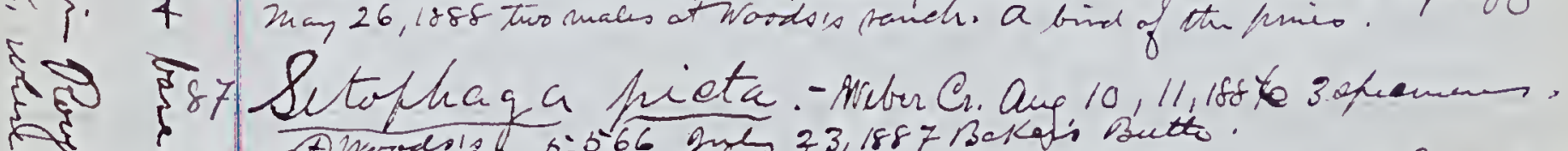

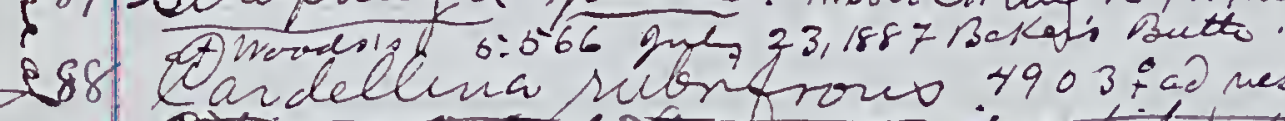

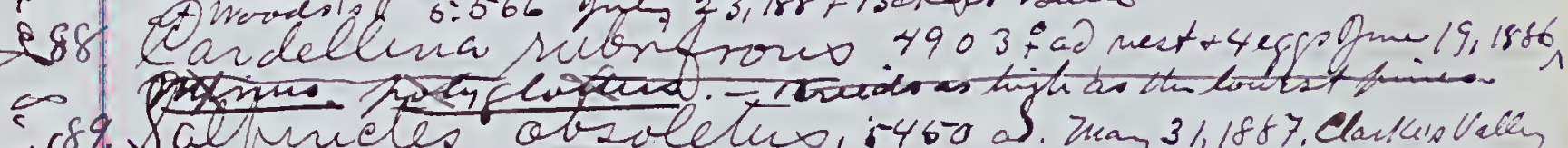

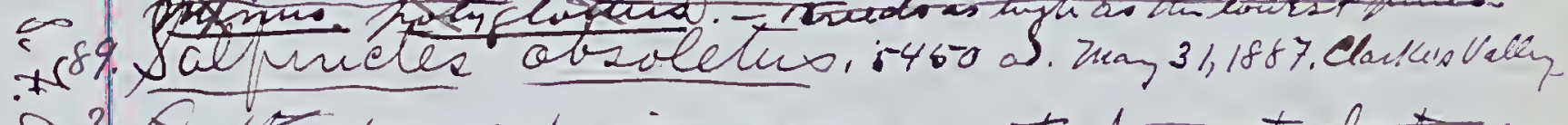

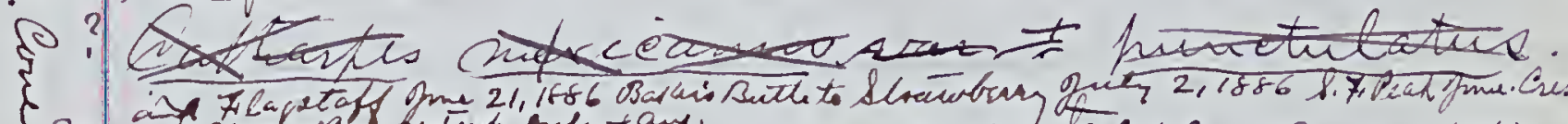

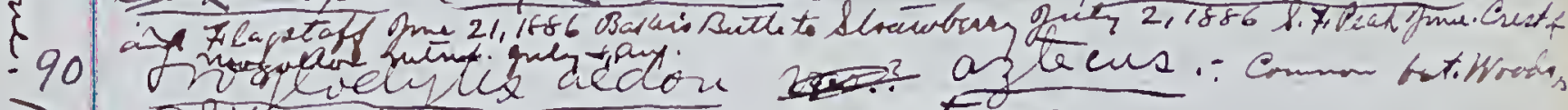

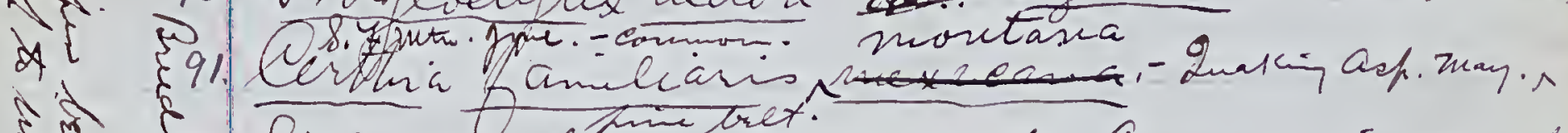

$\$ 92$ Litta earolinimens aculeata. Common renimatio st

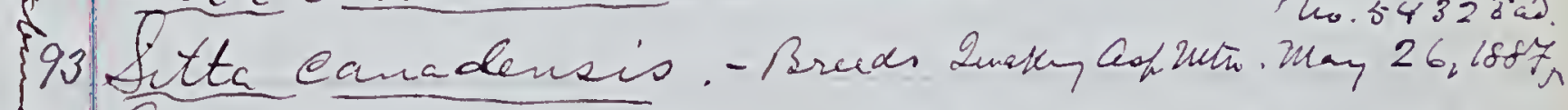

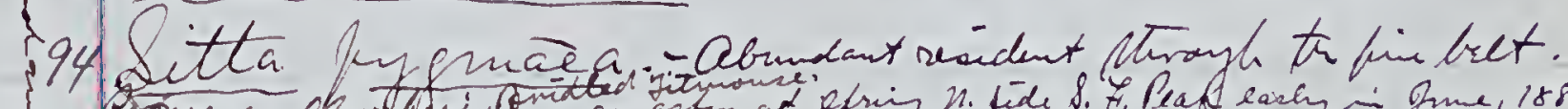

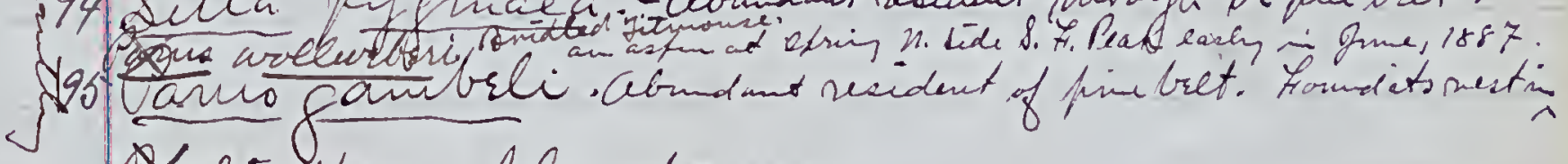

\$ Babtifamoflumbars

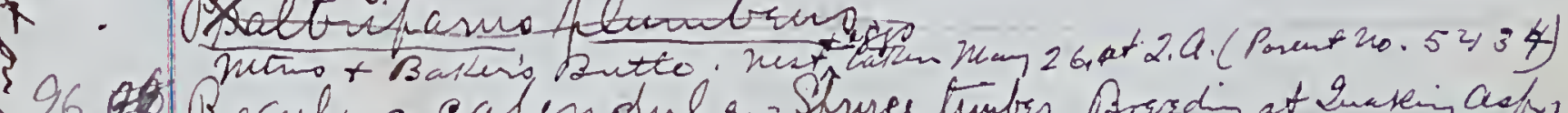

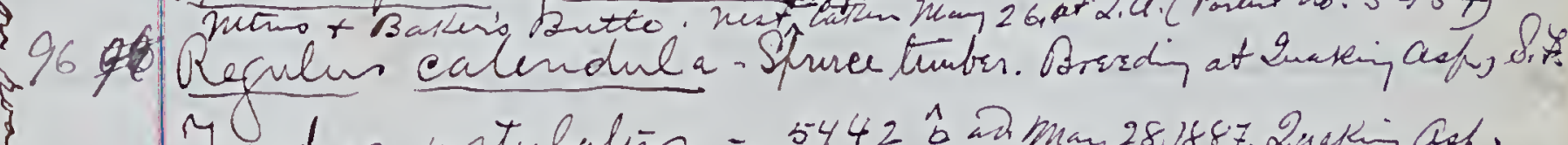

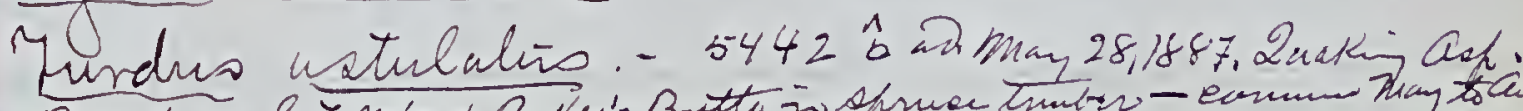

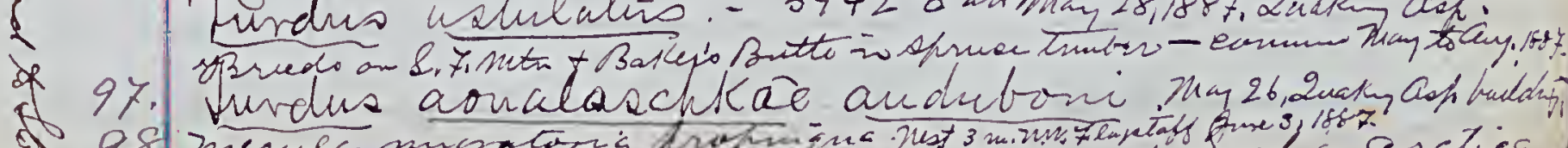

(1) 98 

Shecis to betreated in the body of the liet: -

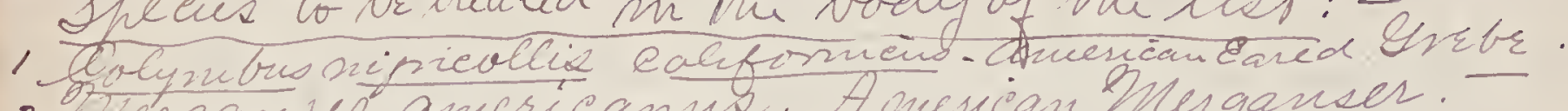

2 Rcraanser ancricanne. Anusican Merganser.

3 Anar boschas. mallard.

4 Arar otherera. Haduall.

sluar amereana. Baedfate.

6 Anar dicorrir. Olue-winged éfeal.

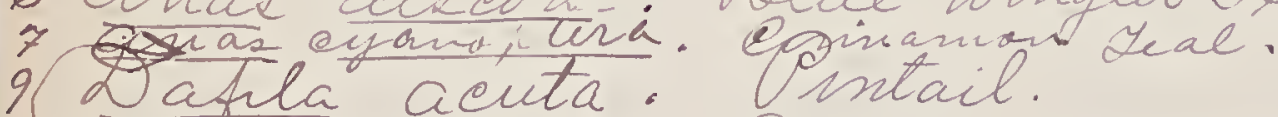

$\checkmark$ Dafila acuta. Sintail.

8 Shanta clyfeata. Shovaller.

10 Erimalira rubida. RuddyDuck.

"lligadis quarauna. White-faced CCosey abi.

12 Dotaun lentiginosur. Amirecair Dittern.

13 Nycheirax njetieonax nâerius. Black-rowned Night Hecron.

" Lns nexicana. Sandhill Erame.

15Yonana Carolina. Dora.

16 Flleca anerieara. Omerièn Got.

1) Aetitix macularia. ifforted S andpifir.

Is Eqialitiz vocifera. Killdeer.

19 Qjptonyx mortezunate. Massena Partridge.

20 A endragapus obcurus. Pusky Grouse.

2.1Mleagrir gallokavo, nexicaina. Hexican Iurky.

-2. Colunba fasciata." Band-tailed Prgeon.

23 enaiduha naeroura. Monrning Dove.

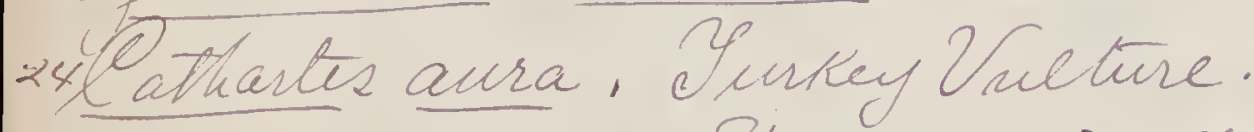

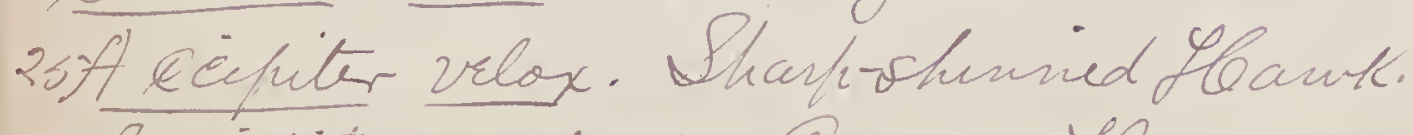

26A Aeifitir cookeri. Cooper's Hawn. 
(4)

so Onneo einerene dorkalis. Red-breked Punco. 76 ifilo ehlorurue, Hren-tailed Lowhel

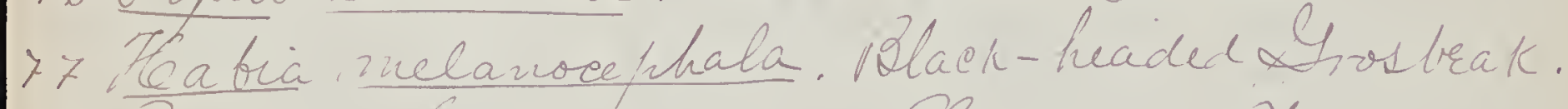

78 Niranga Urdoviciana. Loniaiana Etanager.

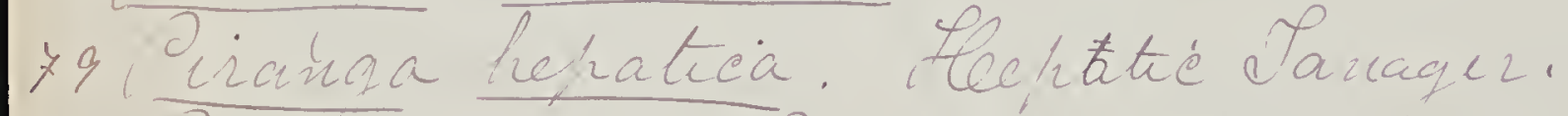

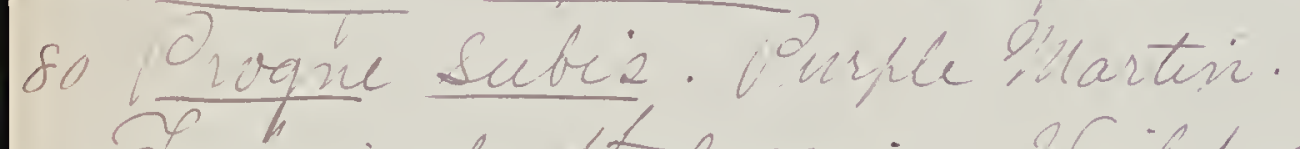

1 Cachyeincta Thalassina. Siolet-grcen Suallow-

$\$ 2$ Vier gibres Swainsoni. Masternwarbling Vineo.

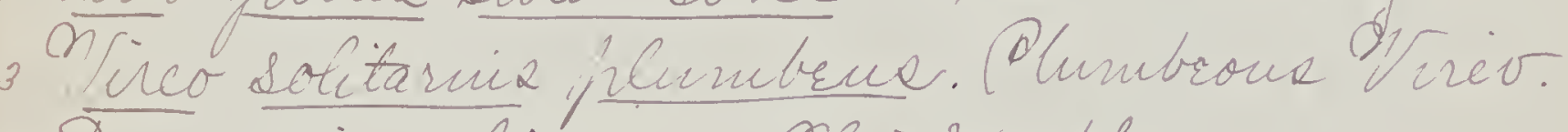

84 Dendrorca olivacea. ChirWarbler.

85 Aendrocia anduboni, Andubon'r Varbler.

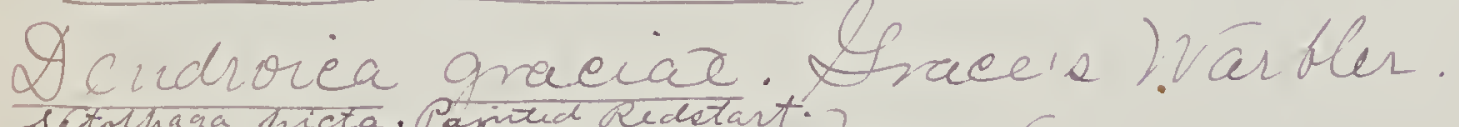

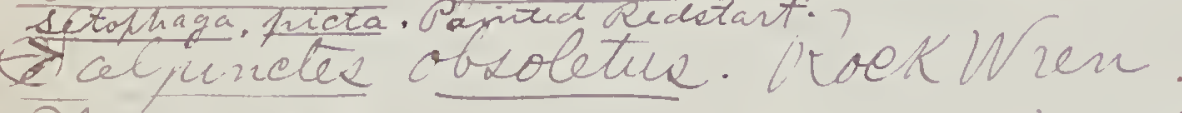

Waivalodyter aëdon aztewe. Weotern Heouse Wren.

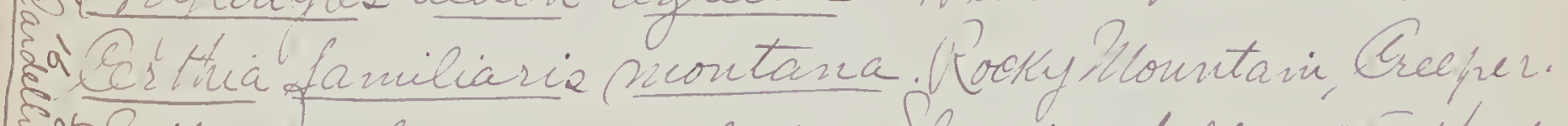

Sitta cavoinensis aculeata. Slender-billed N' uthaté.

Litta camadensis. Red-brrasted Nühateh.

datta hygmata. Prgmy huthatel.

- Dasur qanbeli. Nconntarir Chickader.

calendula. Raby-cromed Ruylet. a onalasehkat andiboni. Audubonis Hecrmit thrush. - mignatonia propingua. Westen Robin.

cialia mexucana. Wutern Pluetrid.

Shalia aretiea. Fuontanid Bluebird. 
Lord over the following notes: - 0

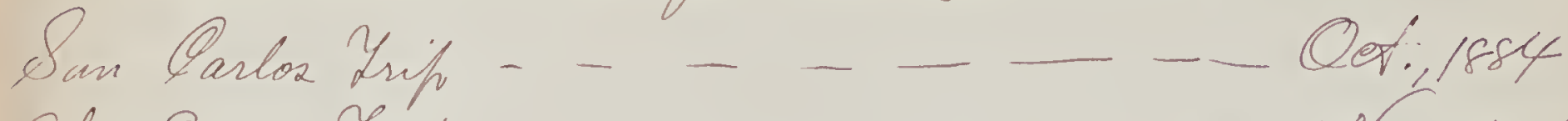

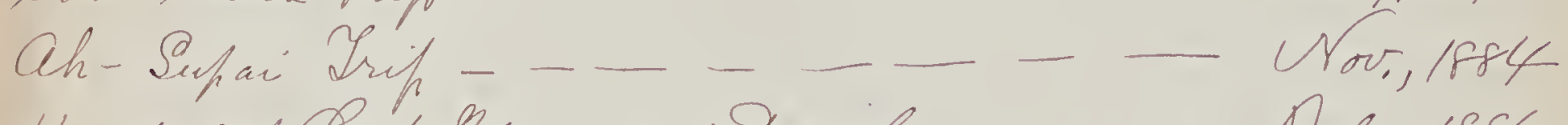

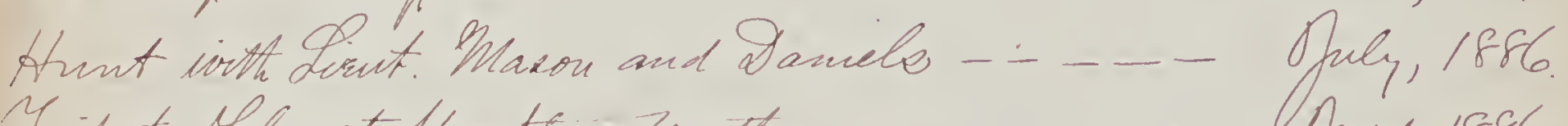

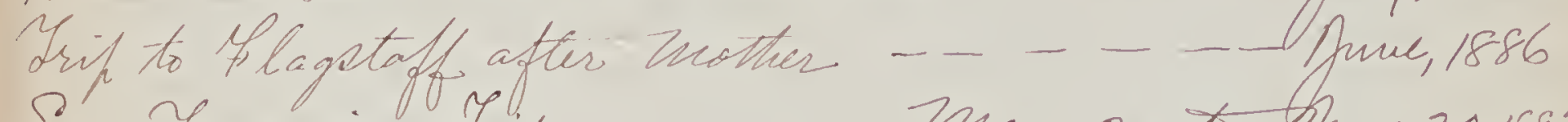

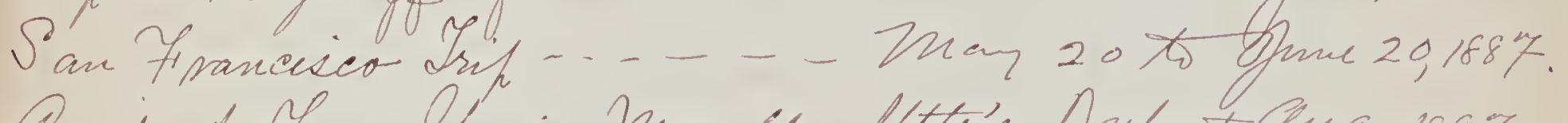

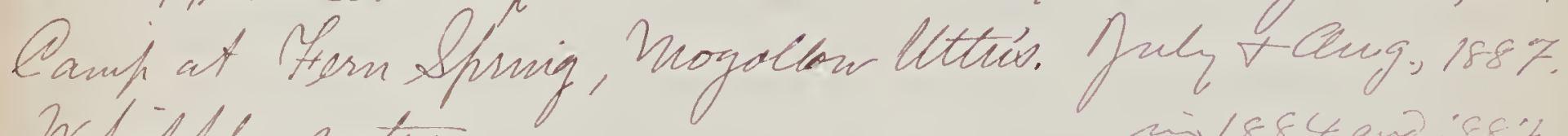
Whipple notes.

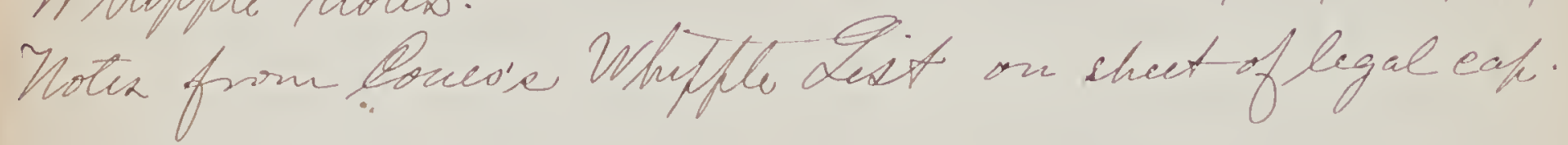


\#6. Omit p. 4, and the letter pusted on top. 127; drevergthing eles, including enclesures. 


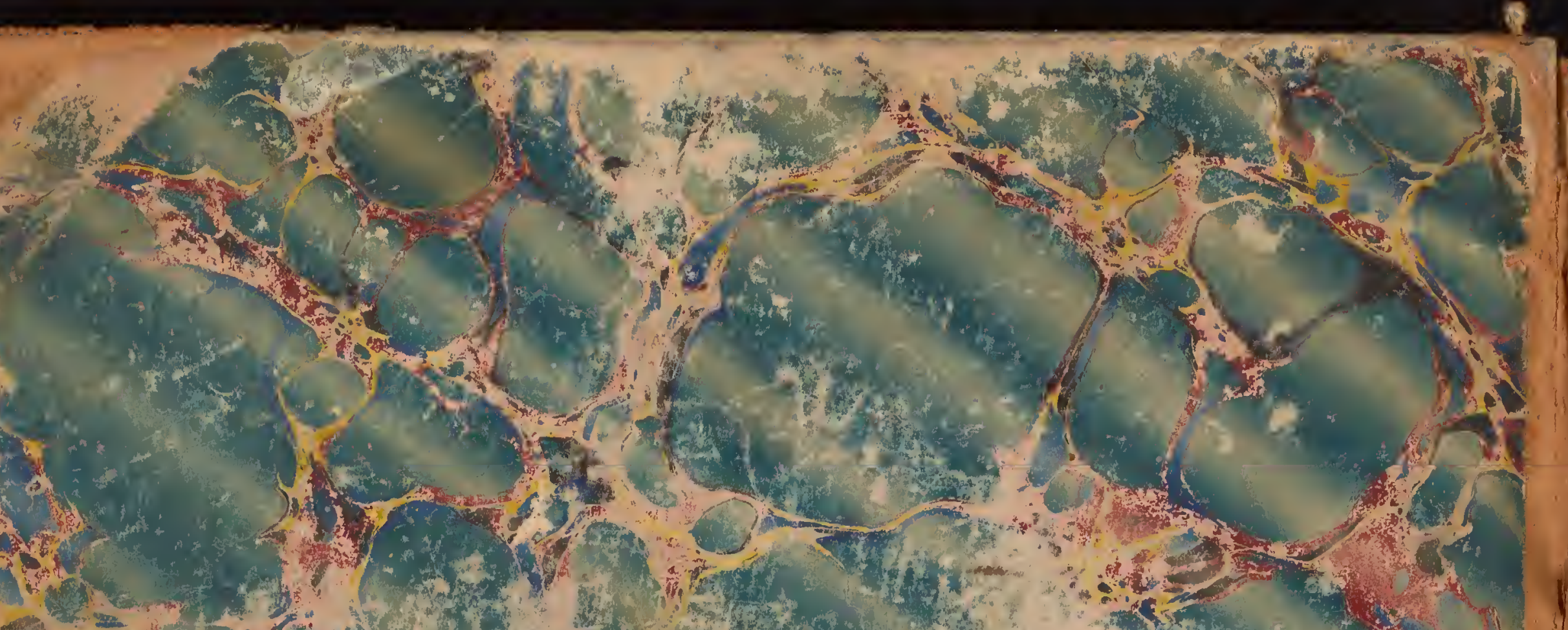

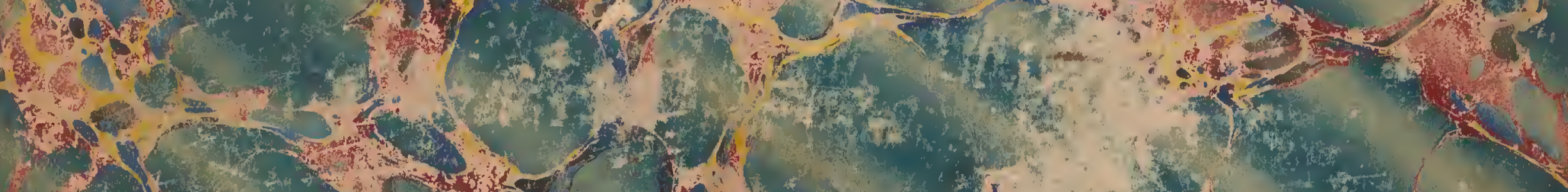
3. 10.40 - $11 \%$

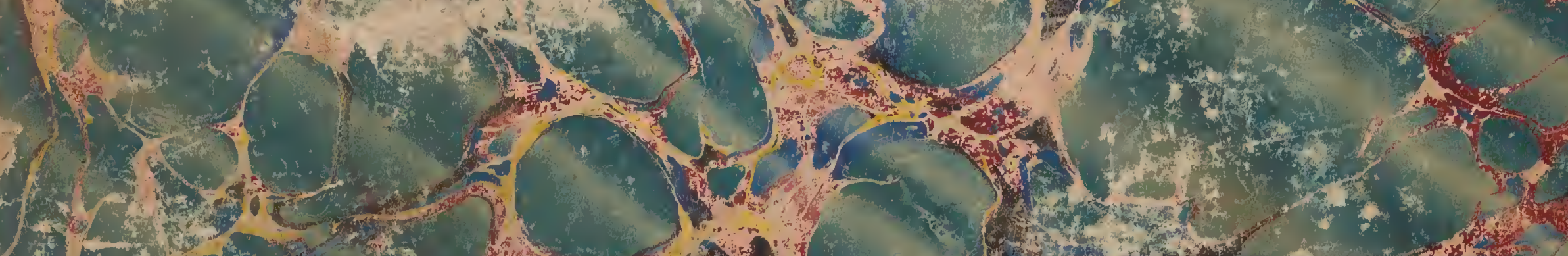

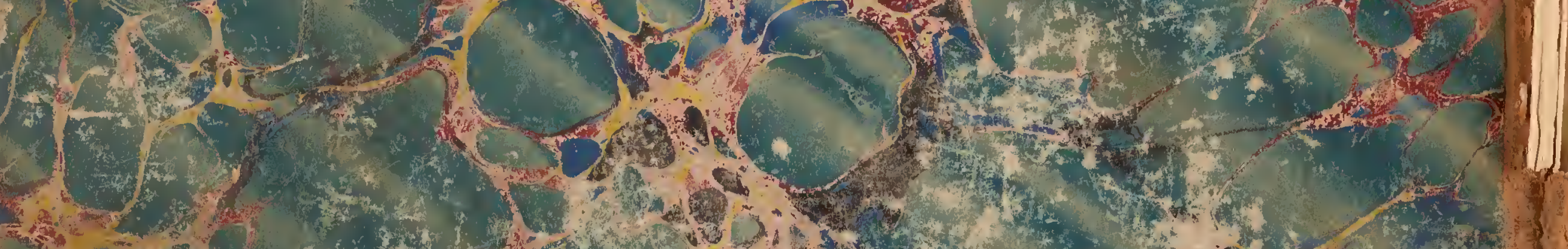

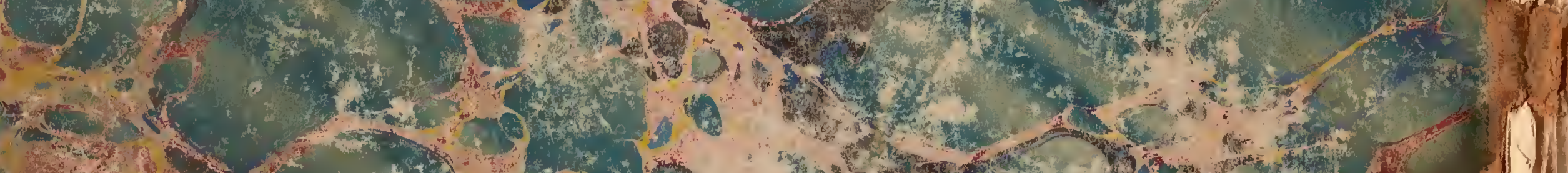

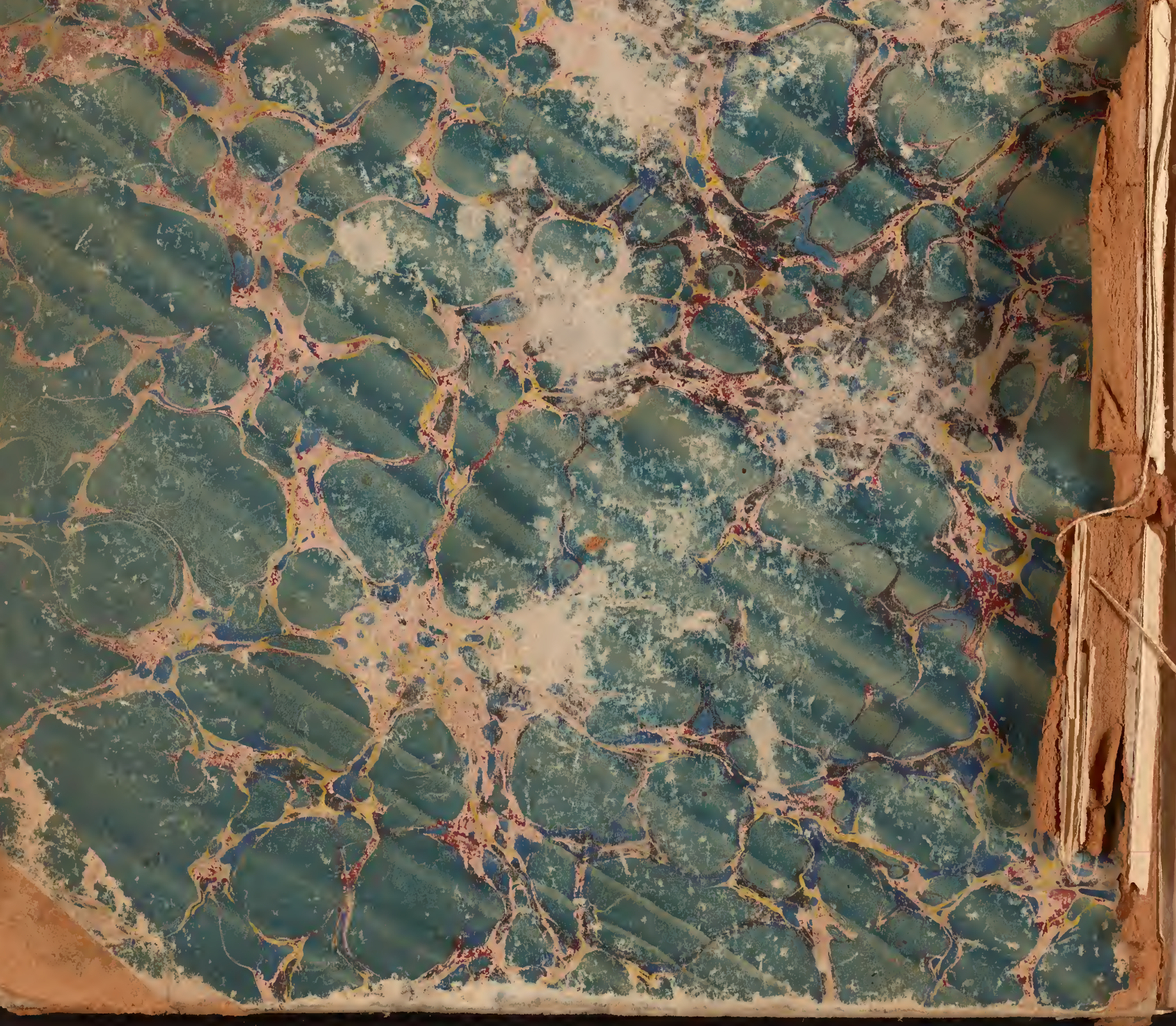

